PLEASE DO NOT DESTROY OR THROW AWAY THIS PUBLICATION. If yen bave no farther use for it, write to the Geological Survey at Washington and ask for a frank to retarn it

UNITED STATES DEPARTMENT OF THE INTERIOR

GEOLOGY OF THE EASTERN PART OF

THE SANTA MONICA MOUNTAINS

LOS ANGELES COUNTY

\title{
CALIFOKNIA
}

GEOLOGICAL SURVEY PROFESSIONAL PAPER 165-C

Diatoms p.114 $/$ pl. 
Please do not destroy or throw away this publication. If you have no further use for it, write to the Geological Survey at Washington and ask for a frank to return it

UNITED STATES DEPARTMENT OF THE INTERIOR

Ray Lyman Wilbur, Secretary

GEOLOGICAL SURVEX

George Otis Smith, Director

Professional Paper 165-C

\section{GEOLOGY OF THE \\ EASTERN PART OF THE SANTA MONICA MOUNTAINS \\ LOS ANGELES COUNTY, CALIFORNIA}

BY

H. W. HOOTS

Shorter contributions to general geology, 1930

(Pages 83-134)

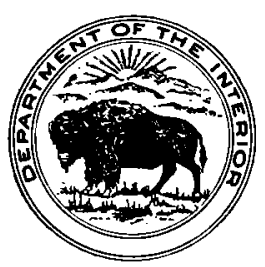

UNITED STATES

GOVERNMENT PRINTING OFFICE

WASHINGTON : 1931

For sale by the Superintendent of Documents, Washington, D. C. - - - - Price 75 cents 



\section{CONTENTS}

Abstract__

Introduction

Previous geologic investigations

Field work and acknowledgments $\ldots \ldots \ldots$

Geography _._.

General geology

Stratigraphy

- Triassic (?) rocks

Santa Monica slate....

- Jurassic (?) rocks

Granite and granodiorite

Upper Cretaceous and Eocene rocks .

Chico formation of the Reseda quadrangle.

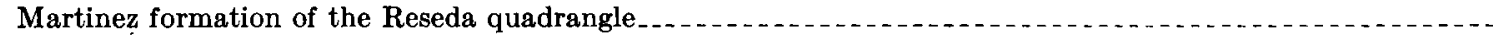

Chico and Martinez formations of the Topanga Canyon quadrangle

Oligocene (?) and lower Miocene rocks

Sespe (?) and Vaqueros (?) formations.

Miocene rocks _.

Topanga formation (middle Miocene)

Area between Stone Canyon and Cahuenga fault $\ldots \ldots \ldots \ldots$

Lower conglomerate member.

Middle conglomeratic sandstone and basalt member $\ldots$

Upper thin-bedded shale and sandstone member

Hollywoodland-Griffith Park area east of Cahuenga fault

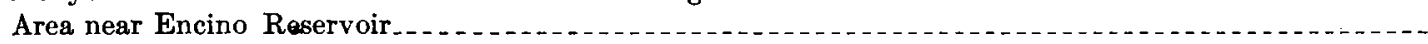

Topanga-Garrapata Canyon area

Area of lower Sepulveda Canyon

Fossils and correlation

Topanga (?) formation on south flank of mountains

Probable middle Miocene trachyte

Modelo formation (upper Miocene)

Definition_.

Distribution and general character.

Lower member...

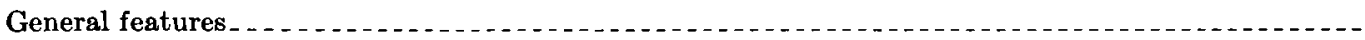

Basal graywacke

Oolitic phosphate

Sandstone._...

Sandstone dikes

Shale ... -

Bituminous shale $\ldots \ldots \ldots$

Fossils and age

Upper member

General features

Microscopic character of shale.

Fossils and age

Pliocene rocks

Potrero Canyon.

San Diego formation (middle or upper Pliocene)

Pliocene near Sawtelle.

Post-Pliocene (?) igneous rocks.

Upper Pliocene or lower Pleistocene rocks.

Lower Rustic Canyon

Upper Pleistocene rocks.

Marine Pleistocene.....

Nonmarine Pleistocene.

Recent alluvium 
General geology-Continued. Page

Structure

Jurassic (?) granitic intrusion $\ldots \ldots$

Post-Topanga and pre-Modelo deformation

Post-Miocene deformation

Character of faults

Summary of structure

Geologic history

Physiography

Santa Monica Mountains;

Santa Monica Plain

Economic geology

Petroleum

Salt Lake oil field $\ldots$

Geology . . .

Stratigraphy

Structure

Development. .

Beverly Hills oil field . $\ldots \ldots \ldots$

Oil possibilities of other areas adjoining the Santa Monica Mountains

Limestone.

Sandstone and basalt $\ldots \ldots \ldots$

\section{ILLUSTRATIONS}

Plate 16. Geologic map of the eastern part of the Santa Monica Mountains, California

17. Structure sections across the eastern part of the Santa Monica Mountains, California

18. $A$, Distorted schist, slate, and phyllite of Santa Monica slate east of Coldwater Canyon, Calif.; $B$, Hand specimen of spotted slate from Sepulveda Canyon, Calif.; $C$, Thin-bedded hard black shale and gray sandstone of Chico formation in Topanga Canyon, Calif

19. $A$, Massive conglomerate of Chico formation in Topanga Canyon, Calif,; $B$, Ledge of white algal limestone of Martinez age ...

20. $A$, Hand specimen of light-gray algal limestone of Martinez age, upper Santa Ynez Canyon, Calif.; $B$, Hand specimen of volcanic agglomerate from Topanga formation

21. $A$, Intrusive basalt with sandstone stringers of Topanga formation; $B$, Pillow structure in upper part of basalt east of Laurel Canyon road, Calif.; $C$, Conglomerate of Topanga formation

22. $A$, One of the many massive units of sandstone in the lower member of the Modelo formation; $B$, Unconformity between basal conglomerate of Modelo formation and conglomerate of Topanga formation; $C$, Basal graywacke of Modelo formation resting on irregular erosion surface of Santa Monica slate

23. $A$, Hand specimen of dark-gray basal graywacke of Modelo formation; $B$, Hand specimen of basal oolitic phosphate of Modelo formation.

24. $A$, Gray cherty shale in lowest shale unit of lower member of Modelo formation; $B$, Noncherty siliceous platy shale in upper shale unit of lower member of Modelo formation; $C$, Sandstone dike in gently tilted Modelo shale ...

25. A, Sill-like intrusion of sandstone in Modelo shale; $B$, Hard white siliceous shale in upper part of lower member of Modelo formation; $C$, Finely laminated white and light-gray punky diatomaceous shale

26. $A$, Finely banded cherty shale from lower part of Modelo formation; $B$, Well-preserved imprint of leaf from land plant in platy shale of lower member of Modelo formation.

27. A, Columnar section of Modelo formation measured near Girard, Calif.; B, Map showing locations of foraminiferal samples collected from Modelo and Pico formations near Santa Monica, Calif.; $C$, Map showing locations of foraminiferal samples collected from Modelo formation near Girard, Calif .

28. Diatoms from upper member of Modelo formation

29. $A$, Coastal bluffs of Pleistocene brown alluvial-plain material; $B$, Indistinct bedding and poor sorting common in the Pleistocene alluvial-plain desposits

30. $A$, View looking west along crest of Santa Monica Mountains, Calif.; $B$, View looking north-northwest along Cahuenga fault, Calif.; $C$, View looking west across Topanga Canyon 1 mile below Topanga, Calif .......-

31. Airplane view looking north at Santa Monica Mountains, Calif

32. Airplane view looking northwest over part of the residential district of western Los Angeles, Calif

33. Subsurface structure contour map of the Salt Lake oil field, Calif

34. Subsurface structure contour map of the Beverly Hills oil field, Calif

Figure 7. Index map of Calif ornia showing areas that include or adjoin oil-producing districts and are described in published reports of the United States Geological Survey

8. Cumulative curves showing texture and degree of sorting of some Miocene and Pleistocene sandstones.......... 


\title{
GEOLOGY OF THE EASTERN PART OF THE SANTA MONICA MOUNTAINS, LOS ANGELES COUNTY, CALIFORNIA
}

\author{
By H. W. Hoots
}

\begin{abstract}
The Santa Monica Mountains lie only a few miles northwest of the city of Los Angeles and comprise one of the prominent structural features that adjoin the Los Angeles Basin, one of the most prolific oil-producing districts of California. Even though the eastern part of these mountains may yield no oil, information concerning the rock types, structural character, and detailed geologic history of this area should be of value to petroleum geologists.

The area described in this report, which lies between Topanga Canyon on the west and the Los Angeles River on the east, presents a section of varied rock types including coarsely crystalline plutonic rocks, basic and acidic intrusive and pyroclastic rocks, metamorphic slate and schist, and a wide assortment of sedimentary rocks. The stratigraphic record is far from complete; the presence of Paleozoic rocks is very doubtful, and there is a gap in the early Tertiary record representing middle and late Eocene time and possibly part of Oligocene time. The Upper Cretaceous is well represented, and probably also the Triassic and Jurassic, although a large part and possibly all of the rocks tentatively considered to represent these two periods may be of Paleozoic age. The record of late Tertiary and Quaternary time, beginning with the lower Miocene, is fairly complete except for a fragmentary exposed Pliocene and Pleistocene record and a gap representing a considerable but unknown amount of the late middle Miocene.

Structurally the eastern part of the Santa Monica Mountains is a broad anticline whose axis lies in the extensive central area of Santa Monica slate (Triassic ?) and plunges westward from the major granitic intrusive mass just north of Hollywood. The attitude of the younger rocks, particularly those of Miocene age which cover so much of the north and south flanks of the mountains, conforms in a general way to this anticlinal structure. It is apparent from the presence of several pronounced unconformities, however, that this major fold has experienced several stages of growth and deformation. The anticlinal structure is still clearly obvious in the central part of the district; but in the eastern and western parts the original fold has been so intricately deformed by block faulting and igneous intrusion that much of the fold is either difficult to recognize as such or is down-faulted and entirely concealed beneath alluvium. Post-Topanga and pre-Modelo diastrophism produced an anticline which, to judge from its westward plunge, was complete in the district east of Topanga Canyon, although similar major uplifts of this age may have occurred farther west; post-Modelo diastrophism (pre-Pliocene and post-Pliocene), however, caused an anticlinal uplift that affected a larger area as a unit, an area which included the district west of Topanga Canyon as well as that east of it.

From the distribution of a remarkable spotted slate within the extensive area covered by the Santa Monica slate and the
\end{abstract}

known relation of the spotted slate to the major exposed granitic intrusive mass, which is of probable Jurassic age, it is believed that much of the area north of the anticlinal axis is underlain by a much larger intrusive body of granitic rock. The broad character of the fold, a unique structural feature for the Coast Ranges of California, is that which might be expected to result from vertical uplift and is in marked contrast to the sharp asymmetrical folds of many Coast Range areas which appear to have undergone considerable lateral compression.

Two structural features of this area are particularly striking. One is the post-Topanga and pre-Modelo unconformity that represents the only period of folding which is comparable in importance with the deformation that occurred near the end of the Pliocene epoch. The other is the remarkably close association between faults and intrusive basalt in the pre-Modelo rocks of the Topanga and Santa Ynez Canyon district, an association which forces the conclusion that faulting and basalt intrusion had a close genetic relation during the period of postTopanga and pre-Modelo diastrophism.

This area contains several types of rock which, to judge from the literature, are not common in California. Some of them are known elsewhere but have not yet been described in detail. The oldest of these unusual rocks is the spotted slate above mentioned, a contact-metamorphic facies of the Santa Monica slate.

Prominent reefs of white marine algal limestone from a few feet to several hundred feet thick occur in the Martinez formation (lower Eocene) and possibly also in the Chico formation (Upper Cretaceous) of some areas. These reefs commonly extend for not more than a few hundred feet and terminate abruptly. The limestone is distinctly nodular, has irregular bedding, and is characteristically spotted, owing to the abundance of nearly white irregularly shaped algae and algal colonies embedded in a limestone or argillaceous matrix of light brown or gray color. The algae appear to be of the lithothamnion type but have not yet been studied in detail.

The Modelo formation (upper Miocene) contains rock types of considerable interest. A massive bed of graywacke, dark gray because of an abundance of detrital slate fragments, occurs at the base. In some places this rock is very fossiliferous; in other places it is absent and its stratigraphic position is occupied by a 4 to 6 inch bed of oolitic phosphate, another type of rock which does not appear in the literature as a common constituent of the California Tertiary. The most distinctive feature of the Modelo formation is the abundance of hard white platy shale, a type of rock which is not at all unusual for the California Miocene but which, because of its highly siliceous character and association with beds of volcanic ash and bentonite, its microfossil content, and its remarkable banding, has proved to be worthy of study. 


\section{INTRODUCTION}

This report covers a low mountain area which lies from 5 to 20 miles northwest of the city of Los Angeles and adjoins the Los Angeles Basin, one of the most prolific oil-producing districts of California. Although it appears unlikely that the eastern part of the Santa Monica Mountains will yield commercial amounts of petroleum, it seems that an understanding of the geology of these mountains will prove a practical aid to wildcat exploration for oil and gas in adjoining lowland areas of the Los Angeles Basin and San Fernando Valley.

\section{PREVIOUS GeOLOGIC INVESTIGATIONS}

W. P. Blake was apparently the first geologist to traverse a part of the Santa Monica Mountains and to record information regarding the types of rock exposed there. Arriving at San Fernando Pass on the evening of October $3,1853,{ }^{1}$ Blake and his party camped by the side of a creek which they later found to be one of the tributaries of the Los Angeles River. Blake's description of their journey southward across the San Fernando Valley and the east end of the Santa Monica Mountains is both pleasing and instructive:

Soon after leaving our camp under the fig trees, we found that we were entering a widely extended valley with a nearly level surface, without trees or verdure, and bounded on all sides by distant ranges of mountains. On turning the point of the hill, we came suddenly in sight of the mission [San Fernando] buildings, which, with the surrounding gardens, stood isolated in the seemingly desert plain and produced a most beautiful effect. The gardens were inclosed by walls, but the graceful palm rose above them, and groves of olive, lemon, and orange trees could be seen within. Outside of the walls the surface was barren and gravelly, and the fertility within is the result of irrigation.

Herds of cattle were seen on parts of the broad plain, feeding on dried grass or the burrs of the California clover, which covers the ground in the latter part of the summer when all the grass has disappeared. This plain doubtless presents a beautifully green surface in the winter and early summer, when watered by the rains. From the mission we passed directly [south] across the plain toward a low range of hills [the east end of the Santa Monica Mountains], which forms the boundary between it and the plain on which Los Angeles is built. The distance across the plain is about 10 miles, and the road was bordered in some places by a low growth of shrubbery and Cactaceae, which gave a peculiar aspect to the country and reminded some of the party of Mexican landscapes. The distant ranges of mountains had a peculiar barren look and in color were of various shades of brown, blue, and purple. When we reached the base of the hills we crossed a running stream, bordered by grass, which we afterwards found to be the Los Angeles River, and then the ascent of the hills immediately commenced.

Range of sandstone hills between San Fernando and Los Angeles: This range appeared to extend nearly east and west, bounding the San Feinando Plain on the south and trending parallel with the Susannah Range on the north side. Like that range, this seemed formed of sedimentary strata, but they were not so well exposed; and we traveled in such haste that few observations on them were made.

1 Blake, W. P., U. S. Pacific R. R. Expl., vol. 5, pp. 73-76, 1856
Toward the summit and near the roadside [probably in Cahuenga Pass] I found an outcrop of erupted rock, which was much obscured by decomposition but showed a globular character, the bank being filled with balls of various sizes, from which successive crusts of the decaying rock were scaling off. It had a dark color and contained considerable oxide of iron, indicated by the dark stains. This intrusive rock is represented on the general geological map, but subsequent observations will doubtless add many important facts to the now limited knowledge of the locality. * * *

View of the Pacific Ocean: In descending from the higher parts of the range, the eye was permitted to wander over an extended area sloping gently away from the mountains toward the west. This is one of the most marked peculiarities of the landscape on the western coast; every mountain and mountain range is flanked by long, gently descending slopes, which seem like plains when passing over them, but viewed from a distance their inclination is strikingly evident. In the present instance the slopes appeared to be prolonged in a limitless plain extending to the horizon, but a more favorable point of view showed to us the broad, mirrorlike surface of the great ocean.

Dr. Thomas Antisell, geologist accompanying an exploring party under the direction of Lieut. John G. Parke, investigated the geology of parts of the Santa Monica Mountains and adjoining districts during the winter of 1854-55. Antisell mentions the occurrence of trachytic and "augitic trap" rocks and states that the range appears to be made up of strata over 500 feet in thickness which consist of hard red and yellow sandstones and "bituminous argillitic beds-soft rocks-including foraminiferous beds." 2 Three structure sections across the mountains accompany the text of his report.

In $1861 \mathrm{~J} . \mathrm{D}$. Whitney, State geologist of California, examined the eastern part of the Santa Monica Mountains and in the short time allotted to this area collected a large amount of remarkably accurate information regarding the major structure of the range and the age of some of the rocks. ${ }^{3} \mathrm{He}$ discovered that the core of this part of the range was composed of "dark siliceous slate" intruded and metamorphosed by granite and that an anticline existed in this old slate in the vicinity of Santa Monica Canyon.

So that we have here one of the best possible examples of a truly anticlinal range of mountains, with a central core of granite, having all the appearance of an intrusive rock which has burst asunder and elevated the slaty strata, producing a highly metamorphic condition of the sedimentary beds along the lines of contact of the granitic mass.

Whitney also presents an instructive north-south structure section across the Santa Susana Mountains, San Fernando Valley, and Santa Monica Mountains. ${ }^{4}$ He describes in detail the series of terraces at the mouth of Santa Monica Canyon and records the finding of fossils in the more eastern part of the range (probably in Brown Canyon or farther east), which W. M. Gabb found to be Miocene.

${ }^{3}$ U. S. Pacific R. R. Expl., vol. 7, pp. 76-78, 1857

3 Whitney, J. D., Cheological survey of California, Croology, vol. 1, pp. 168-171, 1865 ، I Idem, p. 121 
Prof. Jules Marcou, a geologist engaged in exploratory work for the United States Geographical Surveys West of the 100th Meridian, examined geologic features in parts of southern California in $1875-76 . .^{5}$ He discusses in a general way the geology of the eastern part of the Santa Monica Mountains and apparently was particularly interested in the rocks containing fossit fish on the north flank of the mountains near the old Encino ranch-rocks which belong to the Modelo formation and which Marcou correctly classified as to age.

Watts, in the course of his pioneer work on the geology of the oil fields of California, briefly described the rocks exposed in the area west of Cahuenga Pass and also those along the shore west of Santa Monica. ${ }^{6}$

Eldridge ${ }^{7}$ examined the oil-field regions of California for the United States Geological Survey about 1900 and briefly described the general geologic features of the Los Angeles district but gave little or no attention to the Santa Monica Mountains.

The only maps of the geology of the eastern part of the Santa Monica Mountains published by the Geological Survey are those by Ralph Arnold; one of them covers the southern border of the mountains east of the present site of Beverly Hills and accompanies a report on the oil-producing districts of southern California by Eldridge and Arnold. ${ }^{8}$ Arnold's description of the general geologic features in that part of the Santa Monica Mountains covered by his report is in accord with data collected during the present investigation. Another map, largely if not entirely by Arnold, accompanies the railway guidebook for the Coast Line, in which may also be found a brief description of some of the geology of this district.

In 1914 the California State Mining Bureau ${ }^{10}$ published a map of the eastern third of the Santa Monica Mountains. This small-scale map was compiled by C. A. Waring from published reports of the United States Geological Survey and from field work done by R. N. Ferguson. It shows the general distribution of the granite, slate, basalt, and Miocene deposits; Topanga and lower Modelo sandstone and conglomerate on the north flank are classed as Monterey sandstone, the overlying Modelo of the north flank as Monterey formation, and the Modelo of the south flank as the Puente formation. Waring also gave a brief description ${ }^{11}$ of the general stratigraphy and structure of the Los Angeles district and its oil fields.

\footnotetext{
- Marcou, Jules, Report on the geology of southern California: U. S. Geog. Surveys W. 100th Mer., Ann. Rept., for 1876, pp. 158-160, 1876.

- Watts, W. L., oil and gas yielding formations of Los Angeles, Ventura, and Santa Barbara Counties: California State Min. Bur. Bull. 11, pp. 4-5.

7 Eldridge, G. H., The petroleum fields of California: U. S. Geol. Survey Bull. 213, pp. 318-319, 1902.

Eldridge, G. H., and Amold, Ralph, The Santa Clara Valley, Puente Hills, and Los A.sgeles oil districts, southern California: U. S. Geol. Survey Bull. 309, 1907. For geology of the Los Angeles district, includiug part of the Santa Monica Mountains, see pp. 144-202.

- Diller, J. S., and others, Guidebook of the western United States, Part D, The Shasta Route and Coast Line: U. S. Geol. Survey Bull. 614, sheet 1.A and p. 97, 1915 .

10 McLaughlin, R. P., and Waring, C. A., Petroleum industry of California;

California State Min. Bur. Bull. 69, pl. 11, 1914.

11 Idem, pp. 350-358.
}

More recently maps of the Los Angeles Basin have been published which show some of the geologic features of the eastern part of the Santa Monica Mountains. ${ }^{12}$

As a part of a study of the Cretaceous and Eocene deposits of southern California from 1910 to 1917, C. A. Waring ${ }^{13}$ and his associates mapped a northwestsoutheast belt across the central part of the Santa Monica Mountains, extending east and west from Topanga Canyon. This map, a part of which at least apparently is the result of work by a Stanford University geology party of which Waring was a member, shows the presence of the Chico (upper Cretaceous) and Martinez (lower Eocene) formations in the coastal belt east and west of lower Topanga Canyon.

Kew included the northwest corner of the area covered by this report in the area which he described in a recent bulletin. ${ }^{14}$ As mentioned below, Kew also mapped the area farther east on the old topographic base but did not prepare a report before his resignation from the Geological Survey.

Schürmann ${ }^{15}$ made two short trips into the eastern part of the Santa Monica Mountains and apparently also the Puente Hills, during which he noted the general geologic conditions and collected specimens from granitic rocks, slate, diabase, basalt, and andesite. He has described the petrographic character of these specimens and the general field relations of the rock masses from which they were collected.

\section{FIELD WORK AND ACKNOWLEDGMENTS}

W. S. W. Kew, prior to his resignation from the Geological Survey in 1923, mapped the eastern part of the Santa Monica Mountains as a part of a program to complete a geologic study of districts within and adjoining the Los Angeles Basin. His field mapping covered the eastern two-thirds of the area discussed in the present report and was done before the present large-scale and more detailed topographic maps of this region were available. In attempting to transfer Kew's geology from the old to the new maps it became apparent that additional field work would be necessary in order to adjust geologic boundaries to minor topographic features. Numerous new road cuts throughout the area were found to reveal much additional information, and it was decided to remap the area completely and to extend the mapping westward to Topanga Canyon. The writer gratefully acknowledges the valuable assistance derived from occasional field trips and discussions with Doctor Kew and from inspection of his maps, which have been at hand during

$12 \mathrm{Kew}$, W. S. W., A geologic summary of Californis oil felds: Oil Bull., January, 1926. Eaton, J. E., A contribution to the geology of the Los Angeles Basin, California: Am. Assoc. Petroleum Geologists Bull., vol. 10, No. 8, fig. 1, p. 754, 1926. Vickery, F. P., Geology of the Los Angeles Basin: Oil Bull., April, 1928.

13 Waring, C. A., Stratigraphic and faunal relations of the Martinez to the Chico and the Tejon of southern California: Californa Acad. Sci. Proc., 4th ser., vol. 7, No. 4, pp. $53-57$, fig. 3,1917 .

${ }^{14}$ Kew, W. S. W., Geology and oil resources of a part of Los Angeles and Ventura Counties, Calif.: U. S. Geol. Survey Bull. 753, 1924.

1s Schürmann, H. M. E., Beitrag zur Petrographie der Hollywood Hills (Santa Monica-Gebirge) bei Los Angeles: Centralbl: Mineralogie, 1928, Abt. A, pp. 7-13. 
the present study. Field work for this report was done during the summer and fall of 1927.

Dr. R. D. Reed had examined many of the interesting features of the Santa Monica Mountains prior to the present investigation and has served as an unlimited source of inspiration and assistance in problems relating to stratigraphy and sedimentation.

The paleontologic work on the Bryozoa, brachiopods, mollusks, and echinoids by Dr. W. P. Woodring, on

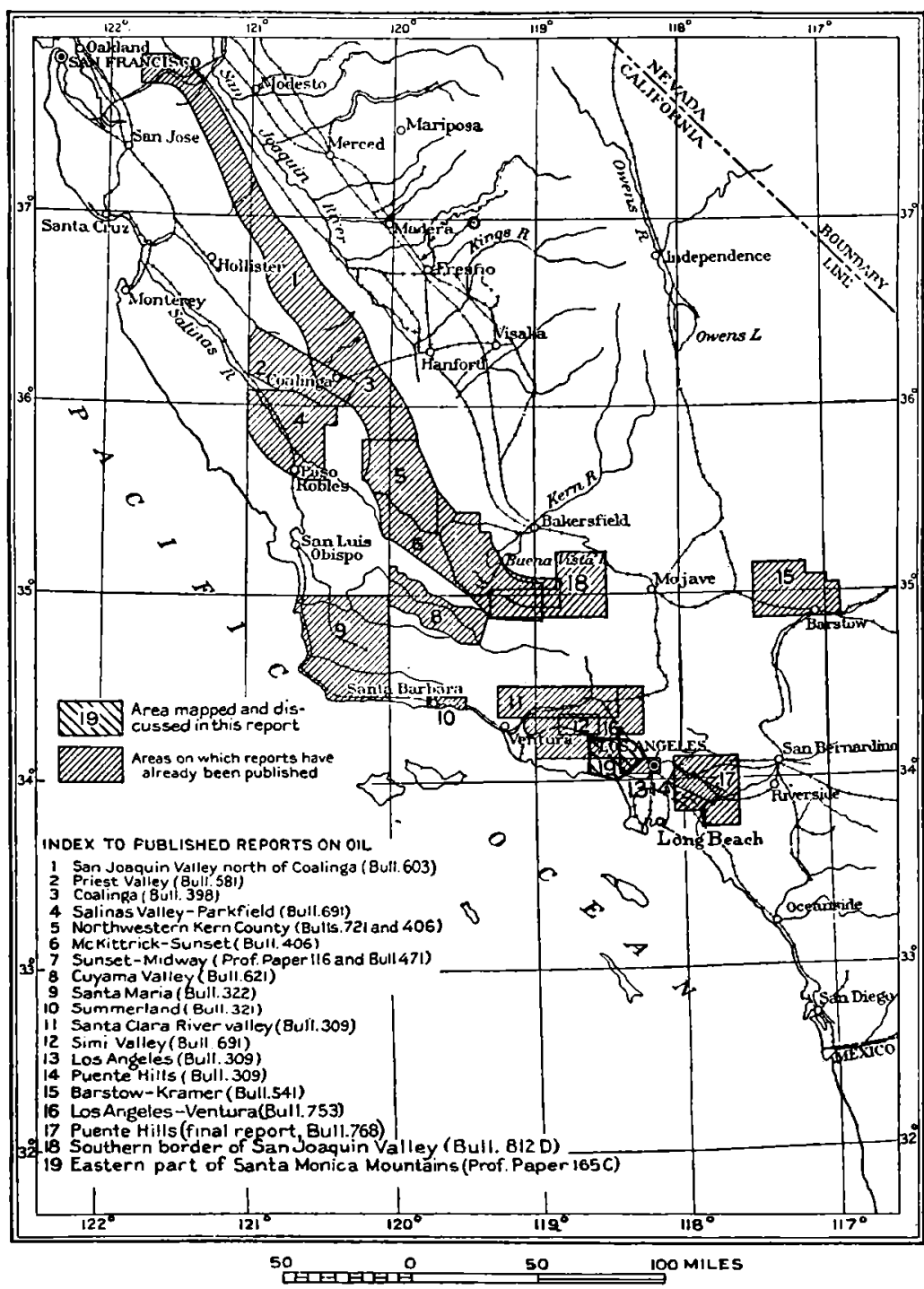

Figune 7.-Index map of California showing areas that include or adjoin oil-producing districts and are described in published reports of the U. S. Geological Survey sils, and his suggestions as to the arrangement of the paleontologic matter in the text. Only with his assistance was it possible to place the marine Pliocene and Pleistocene rocks in their approximate stratigraphic order.

Messrs. W. D. Rankin and W. M. Smith, of Los Angeles, have assisted in the collection of samples of foraminiferal material from the Modelo formation, and Mr. Smith has kindly made several mechanical analyses of sandstone samples. Mr. Lohman, in addition to contributing valuable information regarding diatoms in the Modelo, has made the photographs of rock specimens reproduced in this report. Mr. N. A. Zaitzevsky, of Pasadena, has assisted in the preparation and examination of sandstone samples for their heavy mineral content.

\section{GEOGRAPHY}

The Santa Monica Mountains trend in an east-west direction and form the highlands that adjoin the coast just north of the thirty-fourth parallel. The chain of the Santa Barbara Islands, directly to the west, appears to represent remnants of a westward continuation of this mountain range, much of which is now deeply submerged beneath the Pacific Ocean. The eastern part of the Santa Monica Mountains protrudes into the broad alluvial plains extending southward from the San Gabriel and Santa Susana Mountains and separates the San Fernando Valley on the north from the Los Angeles Basin lowland on the south. A minor southeastward-trending group of hills lies north of the major part of Los Angeles and, were it not for the transverse valleys of the Los Angeles and San Gabriel Rivers, would form a continuous connection between the east end of the Santa Monica Mountains and the Puente Hills. The western part of the Santa Monica Mountains merges northward into the Simi Hills, which separate the San Fernando Valley on the east from the lower part of the Santa Clara River Valley.

The area described in this report (see fig. 7 and pl. 16) comprises the eastern two-fifths of the Santa Monica Mountains and extends from Topanga and Garrapata Canyons on the west to the Los Angeles River near Glendale. It adjoins and includes along its southern border some of the finest residential districts in California, such as Beverly Hills and Hollywood, and its east end is within 5 miles northwest of the business district of Los Angeles. The city of Santa Monica is situated on the coast at the southern edge of the area, indebted to Doctor Woodring for his work on the macroscopic fossils, his assistance in collecting these fosSanta Monica Mountains. The writer is particularly

Hughes, and P. P. Goudkoff, on the diatoms by $\mathrm{Mr}$. K. E. Lohman, and on the fossil plant material by Dr. R. W. Chaney has been indispensable to this investigation, and the conclusions of these men, presented in the following pages, add much to our knowledge of the Cretaceous and Tertiary history of the 
and other beach resorts-Venice, Redondo Beach, and Hermosa Beach-lie directly to the south. Burbank, Glendale, and Pasadena lie to the northeast and eastPasadena about 8 miles from the east end of this area. The San Fernando Valley on the north, with its numerous centers of habitation, such as Van Nuys and Lainkershim, and its broad expanse of intensively cultivated truck gardens, fruit and walnut groves, and farms for dairy cattle, chickens, and rabbits, extends in a broad panorama before the observer who passes along the Mulholland Highway. Practically all of this area, and much of the San Fernando Valley as well, lies within the city limits of Los Angeles. The eastern part of the mountains, east of Stone Canyon, and the southern slopes farther west, which overlook the Pacific Ocean and the Los Angeles Basin, are fast becoming high-class residential property. Some of the accessible canyons, such as Topanga Canyon, contain a fine residence here and there, but more generally only cabins for intermittent use by inhabitants of the cities.

$\Lambda \mathrm{s}$ a result of recent developments most of the area is accessible by automobile, a fact which has greatly facilitated the completion of this project. Hollywoodland and Griffith Park, the area east of Cahuenga Pass and south of Cahuenga Peak, contain a maze of paved streets. West of Cahuenga Pass the crest of the mountains is traversed from east to west by the Mulholland Highway, which connects with the Topanga Canyon road, a north-south highway along the western border of the area. The northern base of the mountains is skirted by the Ventura Boulevard, from which several paved roads branch off to the south, cross the mountains, and lead into Hollywood and Beverly Hills.

The Los Angeles River, the major stream of the district, heads in the Simi Hills and Santa Susana Mountains, to the northwest and north, and flows southeastward across the San Fernando Valley and around the east end of the Santa Monica Mountains. It is an intermittent stream without surface water throughout much of its course during the summer. During the winter, however, this stream, in the vicinity of Glendale and Los Angeles, commonly becomes a torrent over night. Topanga Canyon and others of the major southward-draining canyons of the Santa Monica Mountains, which are fed by permanent springs, contain water throughout the year. Stone, Franklin, and Coldwater Canyons, north and northwest of Beverly Hills, do not themselves contain large permanent streams but are used as the sites for city reservoirs, which are supplied largely by water transported from the Sierra Nevada by aqueduct. Hollywood Lake, just north of Hollywood and east of Cahuenga Avenue, is another such reservoir which, like the others, adds materially to the beauty of the local landscape.
Most of the area described in this report is covered by a substantial growth of brushy vegetation, which presents a serious handicap in mapping the geology, particularly on the crest and southern slopes of the mountains in the western part of the area, where chaparral is so dense as to be practically impenetrable. Chaparral appears to favor the sandy soil derived from Cretaceous, Eocene, and Miocene formations, but the distribution and rankness of this type of vegetation in this area appear to be controlled more by moisture than by soil, as it is much thicker in the fog belt adjoining the ocean than it is farther east and is almost as thick in areas of slate as in areas of sandstone and conglomerate. Surfaces underlain by Modelo shale are commonly covered with grass and white sage and support scattered small black walnut and oak trees. The bottoms of many of the deep canyons, particularly the long ones which drain southward from the crest, are heavily wooded with oak and contain an occasional sycamore and a variety of shrublike undergrowth.

The eastern part of the Santa Monica Mountains, except for small isolated areas, has a strikingly subdued topographic form. The major streams drain southward from the main divide, which occupies an east-west line much nearer the northern than the southern edge of the mountains. The intervening ridge tops are almost flat and are remarkably concordant; for distances of 2 miles or more they extend southward from the divide across the central part of the range with little variation in height. The average altitude of the divide throughout most of the eastern part of the range is between 1,400 and 1,500 feet, although the western one-third of this part is characterized by higher areas and contains some peaks south of the divide and in the central part of the mountains which are 2,125 to 2,150 feet above sea level. The major southward-draining canyons are deep and steep walled and follow comparatively straight courses to the alluvial plain and the Pacific Ocean.

\section{GENERAL GEOLOGY STRATIGRAPHY}

The Santa Monica Mountains present a section of varied rock types, including coarsely crystalline plutonic rocks, basic and acidic intrusive and pyroclastic rocks, metamorphic slate and schist, and a wide assortment of sedimentary rocks. The stratigraphic record is far from complete; the presence of Paleozoic rocks is very doubtful, and there is a gap in the early Tertiary record representing middle and late Eocene time and possibly part of Oligocene time. The Mesozoic appears to be fairly well represented, although Jurassic rocks may not be present and the age of the supposed Triassic deposits is not established. Except for a fragmentary exposed Pliocene and Pleistocene 
record and a gap representing a considerable but unknown thickness of late middle Miocene rocks the record of late Tertiary and Quaternary time, beginning with the lower Miocene, is fairly complete.
The accompanying table gives a list of the rock formations exposed in the eastern part of the Santa Monica Mountains and information regarding their probable age and general characteristics:

Rock formations exposed in the eastern part of the Santa Monica Mountains

\begin{tabular}{|c|c|c|c|}
\hline Geologic age & Formation & $\begin{array}{l}\text { Approximate } \\
\text { thickness (feet) }\end{array}$ & Character \\
\hline \multirow[t]{2}{*}{ Recent............... } & Alluvium & $0-100$ & Breccia conglomerate, sandstone, and silt. \\
\hline & $\begin{array}{l}\text { Alluvial plain deposits now up- } \\
\text { lifted and deeply dissected. }\end{array}$ & $0-300$ & $\begin{array}{l}\text { Poorly sorted reddish-brown breccia conglomerate } \\
\text { and sandstone with earthy matrix and indistinct } \\
\text { bedding. This alluvial plain, now far above present } \\
\text { level of drainage, has been named Santa Monica } \\
\text { Plain }\end{array}$ \\
\hline \multirow{2}{*}{ Pleistocene _- } & $\begin{array}{l}\text { Marine upper Pleistocene } \\
\text { Probable unconformity. }\end{array}$ & $5-100$ & \\
\hline & $\begin{array}{l}\text { Upper Pliocene or lower Pleisto- } \\
\text { cene. }\end{array}$ & 100 & Fossiliferous, conglomerate sandstone and sandy clay. \\
\hline \multicolumn{4}{|c|}{ Unconformity (gently dipping upper Pliocene or lower Pleisto } \\
\hline & Pliocene, upper and lower. $\ldots$ & 1,000 & $\begin{array}{l}\text { Soft dark-gray clay and sandstone with lenses and } \\
\text { concretions of yellowish-gray limestone. Exposed }\end{array}$ \\
\hline \multirow[t]{2}{*}{ Pliocene... } & & & only in coastal belt northwest of Santa Monica. \\
\hline & San Diego tormation (middie or & $0-35$ & Massive sort light-gray conglomeratic sandstone. \\
\hline \multicolumn{4}{|c|}{ (some folding and erosion but extent uncertain because of scanty distribution of Pliocene). } \\
\hline & & 2,300 & $\begin{array}{l}\text { White punky diatomaceous and foraminiferal shale } \\
\text { and fine sandstone, grading laterally into clay shale } \\
\text { and sandstone. }\end{array}$ \\
\hline Upper Miocene... & Modelo formation _. - & 2,250 & $\begin{array}{l}\text { Soft light-gray to brown well-bedded shale, banded } \\
\text { hard platy siliceous shale, thin and thick massive } \\
\text { beds of sandstone and conglomeratic sandstone, } \\
\text { and volcanic ash. Much of shale is foraminiferal. }\end{array}$ \\
\hline \multicolumn{4}{|c|}{ Unconformity (represents the most pronounced pre-Pliocene deformation, which included folding, faulting, and basalt intrusion). } \\
\hline Middle Miocene........ & Topanga formation. & $4,500-7,500$ & $\begin{array}{l}\text { Massive fossiliferous sandstone and conglomerate } \\
\text { and thin-bedded shale and sandstone intercalated } \\
\text { with intrusive and extrusive basalt and pyroclastic } \\
\text { rocks of lower and upper Topanga age. Basal } \\
1,000 \text { feet of conglomerate between Stone Canyon } \\
\text { and Cahuenga Avenue may be Vaqueros. }\end{array}$ \\
\hline $\begin{array}{l}\text { Lower Miocene (?) and } \\
\text { Oligocene (?). }\end{array}$ & $\begin{array}{l}\text { Vaqueros (?) and Sespe (?) for- } \\
\text { mations. }\end{array}$ & $3,500-4,000$ & $\begin{array}{l}\text { Light-gray and red conglomerate and conglomeratic } \\
\text { sandstone. Unfossiliferous. }\end{array}$ \\
\hline \multicolumn{4}{|c|}{ Unconformity (a notable stratigraphic gap produced, at least in part, by folding and erosion of uncertain magnitude) } \\
\hline Lower Eocene...........- & Martinez formation & $250+$ & $\begin{array}{l}\text { Soft brown shale, sandy shale, and sandstone, with } \\
\text { hard limestone concretions containing fossils. } \\
\text { Prominent discontinuous reefs of white algal lime- } \\
\text { stone. }\end{array}$ \\
\hline Upper Cretaceous & Chico formation & $8,000+$ & $\begin{array}{l}\text { Massive brown and gray conglomerate and sandstone } \\
\text { and dark-gray shale. Fossiliferous. May also con- }\end{array}$ \\
\hline \multicolumn{4}{|c|}{$\begin{array}{l}\text { Unconformity (not exposed, but unquestionably present because of striking difference in metamorphism of Cretaceous rocks and } \\
\text { older slates, exposed contacts of which are faults). }\end{array}$} \\
\hline Jurassic(?) - & Granitic intrusion $\ldots . . . . . .$. & & Granite and granodiorite. May be of Paleozoic age. \\
\hline & Santa Monica slate $\ldots$ & $5,000-7,000$ & $\begin{array}{l}\text { Black slate, much of which has undergone contact } \\
\text { and regional metamorphism and is locally altered } \\
\text { to mica schist. Base not exposed. }\end{array}$ \\
\hline
\end{tabular}

\section{TRIASSIC (?) ROCKS}

SANTA MONICA SLATE

A large area in the central part of the district covered by this report (see pl. 16), comprising about onefourth of the total area described, consists of darkgray and bluish-gray to black slate which is herein named the Santa Monica slate, from its extensive exposures in the central area of the Santa Monica Mountains, east of Topanga Canyon. No fossils have been found in this formation, but in view of its similarity to the fossiliferous Triassic slate of the Santa Ana Mountains, ${ }^{16}$ both in lithologic character

10 Mendenha'l, W. C., in Willis, Bailey, and others, Index to the stratigraphy of North America: U. S. Geol. Survey Prof. Paper 71, pp. 505-506, 1912. Smith, J. P., The Middle Triassic marine invertebrate tauna of North Ame a: U. S. Geol. Survey Prof. Paper 83, p. 145, 1914. and in its relations to fossiliferous Cretaceous rocks and an earlier granitic intrusion, the Santa Monica slate is considered to be of probable Triassic age. It is entirely possible, however, that this slate and the younger granitic intrusion are both Paleozoic or both Jurassic. Except for metamorphic facies and small areas of basalt intrusions the entire formation is remarkably uniform in character and consists essentially of hard dark-gray slate with only a few thin beds of equally hard light-gray siltstone and fine to coarse quartzitic sandstone. Locally some of the slate is soft and can be easily dug into with a hammera condition which lends encouragement to the hope that fossils once deposited in this old altered mudstone have not been entirely destroyed and may yet 
be found. Weathered surfaces are commonly brown, owing to the abundance of limonite deposited by percolating waters along joints and bedding or cleavage planes, and offer a rather distinct color contrast between slopes of this rock and the intrusive granite and granodiorite.

Slaty cleavage is well developed and, wherever bedding is distinct, is parallel to the original bedding planes of the rock. As a result of the fissile nature and the abundance of joints the slate commonly weathers to chips and thin slabs only a few inches across, a characteristic which tends to prevent this rock from being of commercial value for building.

Much of the slate is altered by contact metamorphism induced by the Jurassic (?) granitic intrusion. A zone 1,500 to 2,000 feet wide adjoining the major granitic mass north of Beverly Hills (see pl. 16) and a larger mass farther west between Brown and Sepulveda Canyons consists largely of mica schist and dark-gray phyllite. This rock, although commonly having a fairly uniform structure, is locally cut by numerous quartz veins and is very much distorted. (See pl. 18, A.) The outer boundary of the eastern schistose zone parallels, in a general way, the border of the intrusive mass and, as indicated on the geologic map, separates this zone from an extensive belt of spotted slate, the approximate distribution of which has been mapped. The spotted slate in turn appears to grade into ordinary unspotted slate through a zone in which the individual spots become progressively smaller and finally disappear.

Plate $18, B$, is a photograph of a hand specimen of the spotted slate. Most of these spots are welldeveloped crystals, apparently of the mineral cordierite. Their development within this rock may be seen in thin sections to have produced a striking reorientation of the slaty cleavage within the crystal boundaries. Each spot is an individual crystal, but there is in many places a slight difference in the extinction of parts of the crystal, such as between the border or irregular areas and the remainder of the crystal. The crystals are roughly spindle-shaped, but a few have good prismatic form with parallel extinction, negative elongation, and rarely distinct transverse cleavage. The crystals are heavily charged with inclusions of biotite and a dark indeterminate substance. Zonal growth made apparent by zonal distribution of inclusions or concentric variations in the birefringence is common. The birefringence is low, being about that of quartz. The index of refraction in most crystals is only slightly less than 1.57 , but in others it may be slightly greater than 1.57 . The sign of the mineral is commonly negative, with $2 \mathrm{~V}$ indeterminate, but some oblique sections suggest positive sign and moderate $2 \mathrm{~V} .^{17}$

\footnotetext{
${ }^{17}$ Dr. A. O. Woodford, of Pomona College, has been very helpful in determining these properties and identifying this mineral.
}

The distribution of the spotted slate is irregular and widespread, and the occurrence of much of this rock has no apparent relation to exposed masses of the granitic intrusive. In view of the relation of some of the schist and spotted slate to the main granitic mass farther east and of the occurrence in foreign countries of other bodies of schist and spotted slate as the product of contact metamorphism, ${ }^{18}$ it seems probable that the wide distribution of these two types of rock in the central and northern part of the slate-schist area is the result of metamorphism by a buried body of granite, which may well form an east-west underground connection between the widely separated granitic masses now exposed.

The writer did not find schist and spotted slate closely associated with the minor granitic masses farther west along the Mulholland Highway and can offer no reasonable explanation for their apparent absence. Additional field investigation may provide an explanation for this discrepancy.

\section{JURASSIC (?) ROCKS}

\section{GRANITE AND GRANODIORITE}

The Santa Monica slate in the central part of this area is intruded by granite, diorite and granodiorite, which, in turn, like all other rocks of this region older than upper Miocene, are cut by numerous minor intrusions of basalt. The intrusive relations of the granitic rocks with the slate are most evident in Higgins Canyon and in road cuts on the adjoining ridge to the east. At these localities stringers of glate and schist are included in the granite, and small elongate masses of granite occur in the slate. Here and elsewhere along the contact both the granite and the Santa Monica slate are cut by innumerable veins of white quartz.

The easternmost part of the mountains, in and near Griffith Park, contains several irregular masses of granitic rocks, most of which have been brought to the surface by faulting. Generally where the granite is not in fault contact with other rocks in this area and in the district west of Cahuenga Avenue it is overlain, with normal depositional contact, by lower Miocene conglomerate.

These granitic rocks are variable in character and consist of light-gray biotite granite and dark-gray diorite and granodiorite, the last consisting of green hornblende, quartz, orthoclase and plagioclase feldspar, and biotite, together with apatite, zircon, and garnet in varying proportions. ${ }^{19}$ The granodiorite

18 One of the best-known examples of the development of spotted slate as a result of contact metamorphism by a granite intrusion is that of the Steiger Schiefer in Alsace-Lorraine, described by Rosenbusch (Die Steiger Schiefer und ihre ContactZone an den Granititen von Barr-Andlau und Hochwald: Abh. zur Geol. Specialkarte von Elsass-Lothringen, Strassburg, 1877). For a description of Rosenbusch's results see Teall, J. J. H., British petrography, pp. 373-375, London, 1888, or Hatch, F. A., and Rastall, R. H., Textbook of petrology, The sedimentary rocks, pp. 251254, London, 1923.

19 For a more detailed petrographic description of some of the plutonic rocks see Schürmann, H. M. E., Beitrag zur Petrographie der Hollywood Hills (Santa Monica-Gebirge) bei Los Angeles: Centralbl. Mineralogie, 1928, Abt. A, pp. 7-13. 
near the border of the large intrusion north of Beverly Hills is distinctly gneissic and highly micaceous, a characteristic which is well exposed in and near Franklin Canyon.

These granitic rocks are almost invariably deeply weathered and crop out as soft masses which have undergone marked disintegration and partial decomposition of mineral aggregates. These deeply weathered plutonic rocks are commonly less resistant to erosion than the lower Miocene conglomerates.

Inasmuch as there are reasons for suspecting that similar granitic masses in the Santa Lucia Mountains, farther north in the Coast Ranges, are pre-Franciscan (pre-Jurassic?), the possibility must be considered that the granite and granodiorite of the Santa Monica Mountains are also pre-Jurassic and of Triassic or Paleozoic age.

\section{UPPER CRETACEOUS AND EOCENE ROCKS}

In the western part of the area covered by this report, in the Topanga Canyon and Reseda quadrangles, a large area is covered with rocks of the Upper Cretaceous (Chico) and lower Eocene (Martinez) age, which in most of the area have not been separately mapped because of a dense covering of brush and unexposed structural complications. Separation has been possible, however, in the Reseda quadrangle, where the structure is relatively simple and the lithologic and faunal distinctions between the Chico and Martinez formations are readily determinable.

CHICO FORMATION OF THE RESEDA QUADRATGLE

The Chico formation in the Reseda quadrangle, the northwestern part of the area here described, crops out along and north of the Mulholland Highway, but has its greatest areal exposure just south of this highway. It is readily divisible into two distinct members-a lower one that consists entirely of very soft friable red conglomerate and sandstone, lying directly on the Santa Monica slate, and an upper one which consists in greater part of hard massive greenish-brown and gray. conglomerate but contains intercalated units of hard dark-gray thin-bedded shale, sandstone, and limestone and thick beds of light-gray conglomeratic sandstone. (See pls. 18, $C$, and 19, A.) Some of the beds of hard dense limestone contain Scaphites and Baculites, and the light-gray sandstone locally yields a variety of other mollusks in addition to several species of ammonites.
The lower member of soft red conglomerate and sandstone, together with its relations to the underlying slate and the overlying upper member of the Chico, is best exposed on the Mulholland Highway just west of the area of slate shown on Plate 16. The rock, like that of the overlying member, is arkosic and contains well-rounded and polished cobbles of varicolored quartzite, dense poryphy, granite, and basalt, together with chips of black slate. Although a cleancut contact is not exposed, it probably rests with normal depositional contact upon the Santa Monica slate, and it appears to grade upward into the overlying more highly indurated brown conglomerate. The thickness of the lower red conglomerate member varies in the direction of the strike, but along the Mulholland Highway it is approximatcly 750 feet. Farther south this member rapidly decreases in thickness, although the thinning may be due in part to displacement along an unmapped branch of the Temescal fault.

The upper member, although containing considerable sandstone and shale and some limestone, is composed of hard massive brown conglomerate to the extent of about 75 per cent. This conglomerate presents a compact mass of rounded cobbles which average from 3 to 5 inches in diameter, embedded in a matrix of clean micaceous sandstone having a marked greenish-brown tinge. This matrix is one of the most distinctive characteristics of much of the conglomerate of the Chico and is in striking contrast to the light-gray arkosic matrix common to conglomerates of Miocene age. This upper Chico conglomerate, although compact and well indurated is only fairly resistant to erosive agencies and commonly weathers to rounded slopes of reddish-brown color.

The total exposed thickness of the upper member of the Chico formation in the Reseda quadrangle is about 2,500 feet. In the northern border of its outcrop it is overlapped unconformably by the Modelo formation (upper Miocene), but farther south it is overlain with apparent structural conformity by fossiliferous shale and limestone of Martinez (lower Eocene) age.

Fossils collected from the lower and upper parts of the upper member of the Chico formation in this area are listed in the accompanying table under localities $16,18,19$, and 22 . W. P. Woodring materially assisted the writer in making fossil collections from the Chico and Martinez. His identifications of the Chico fossils collected from the Reseda quadrangle and also from the area farther south appear in the following table: 
Fossils from the Chico formation of the eastern part of the Santa Monica Mountains [Locality numbers plotted on Plate 16. For description of localities see pp. 123-124]

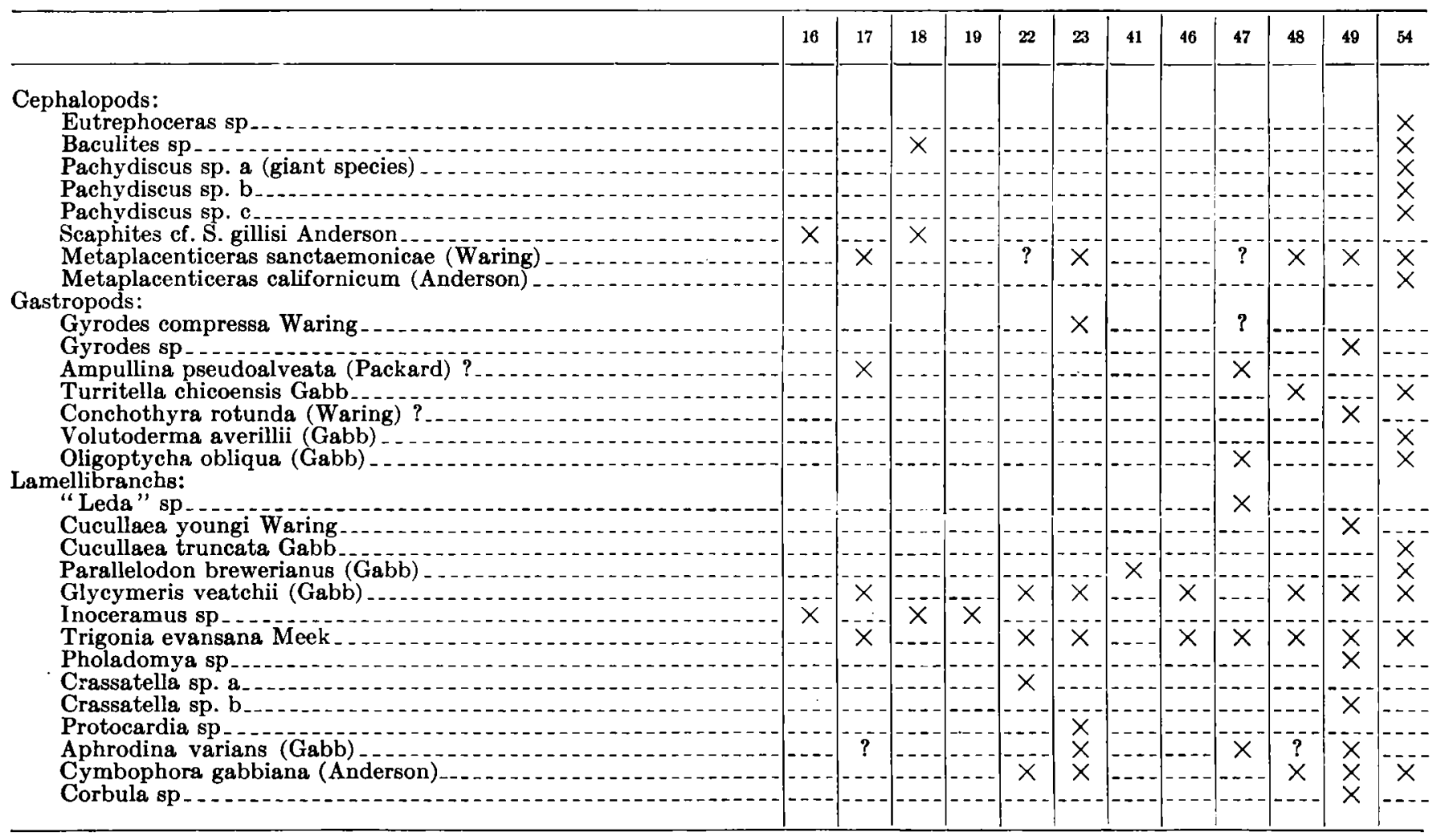

Doctor Woodring makes the following comments regarding these Chico fossils:

Metaplacenticeras is recorded elsewhere from the basal part of the Chico formation, which is regarded as of Cenomanian age. 20 Aside from Melaplacenticeras californicum the rather meager ammonite fauna from the Santa Monica Mountains is not similar to that recorded by Anderson from the lower Chico of the Santa Ana Mountains. As more than one horizon is included in the lower Chico it seems probable that the beds in the Santa Monica Mountains represent a higher horizon than those in the Santa Ana Mountains carrying Acanthoceras. None of the specimens referred to Metaplacenticeras sanctamonicae and $M$. californicum has the tricarinate venter characteristic of $M$. pacificum (Smith), the type of the genus, up to a diameter of 100 millimeters.

Thirteen species of Chico fossils have already been recorded by Waring ${ }^{21}$ from a locality in the eastern Santa Monica Mountains.

\section{MARTINEZ FORMATION OF THE RESEDA OUADRANGLE}

Near the head of Santa Ynez Canyon, in the southern part of the Reseda quadrangle, the coarse conglomerate of the Chico formation is overlain by a comparatively thin unit of shale, sandstone, and limestone which has yielded a few fossils characteristic of the Martinez formation (lower Eocene). The shale is compact and well bedded and varies in color from light

\footnotetext{
${ }^{20}$ Smith, J. P., California Acad. Sci. Proc., 3d ser., vol. 1, p. 204, 1900. Anderson F. M., idem, vol. 2, pp. 27, 28, 34, 79-80, 1902. Reeside, J. B., jr., U. S. Geol. Survey Prof. Paper 147, p. 2, 1926.

"1 Waring, C. A., California Acad. Sci. Proc., 4th ser., vol. 7, pp. 56-71, 1917 (locolity 3).
}

brown to gray. It is sandy in part and is interbedded with thin layers of fine sandstone and with prominent but discontinuous reefs of white algal limestone.

In this locality the Martinez formation has an approximate thickness of 250 to 350 feet. Although the change at the Chico-Martinez contact from the massive upper conglomerate of the Chico to the overlying shale is abrupt and may well represent a break in sedimentation and a resulting hiatus in the stratigraphic record, there appears to be no discordance in either dip or strike of the two formations. The Martinez in this locality is, however, definitely unconformable with the overlying Vaqueros(?)-Sespe(?), there being a complete absence of much if not all of the middle and upper Eocene and a difference in strike of at least $30^{\circ}$ and in dip of about $20^{\circ}$ between the two formations in contact.

Fossil collections from brown shale at localities 26 and 27 have yielded several species, but the white algal limestone at locality 21 contains only unidentifiable fragments of mollusks. A giant "Lima" was collected from the algal limestone at locality $67 \mathrm{C}$, in the Topanga Canyon quadrangle, near the limestone quarry in upper Santa Ynez Canyon. The best collection of Martinez fossils from the Reseda quadrangle came from a gray limestone concretion associated with shale and white algal limestone in a small isolated patch farther north (locality 62), apparently faulted into the basal part of the Modelo formation. 
The algal limestone is one of the most striking and probably the most unusual rock types in the Santa Monica Mountains. It occurs in prominent white reefs from a few feet to several hundred feet thick which vary in lateral extent from only a few feet to about 4,000 feet and commonly. terminate in an abrupt wall. The outcrop of a typical ledge of algal limestone is shown in Plate $19, B$. This limestone is distinctly nodular and has irregular bedding. Although weathered outcrops are commonly white, some black or very dark gray algal limestone occurs, and fresh exposures of even the white-weathering rock have a characteristically spotted appearance due to the abundance of nearly white irregularly shaped algae and algal colonies embedded in a limestone matrix of light-brown or gray color. In some places there appear to be all grades of purity of this limestone, a condition which may be noted in single outcrops or even in hand specimens where comparatively pure white or light-brown algal limestone grades laterally or vertically into a darker-gray algal rock with a matrix that is highly argillaceous. Commonly this increase in argillaceous material is accompanied by a decrease in the number of algal growths. Well-rounded cobbles of quartzite or granite occur here and there within these limestone deposits.

Additional information regarding the character, tonnage, and plans for commercial exploitation of the Eocene limestone deposits is given on pages 133-134.

In the table below appears a list of fossils collected from the Martinez formation of the Reseda quadrangle and from beds of the same age in the Topanga Canyon quadrangle, farther south. These fossils have been identified by W. P. Woodring.

Fossils from the Martinez formation of the eastern part of the Santa Monica Mountains

[Locality numbers plotted on Plate 16. For description of localities, see pp. 123-124]

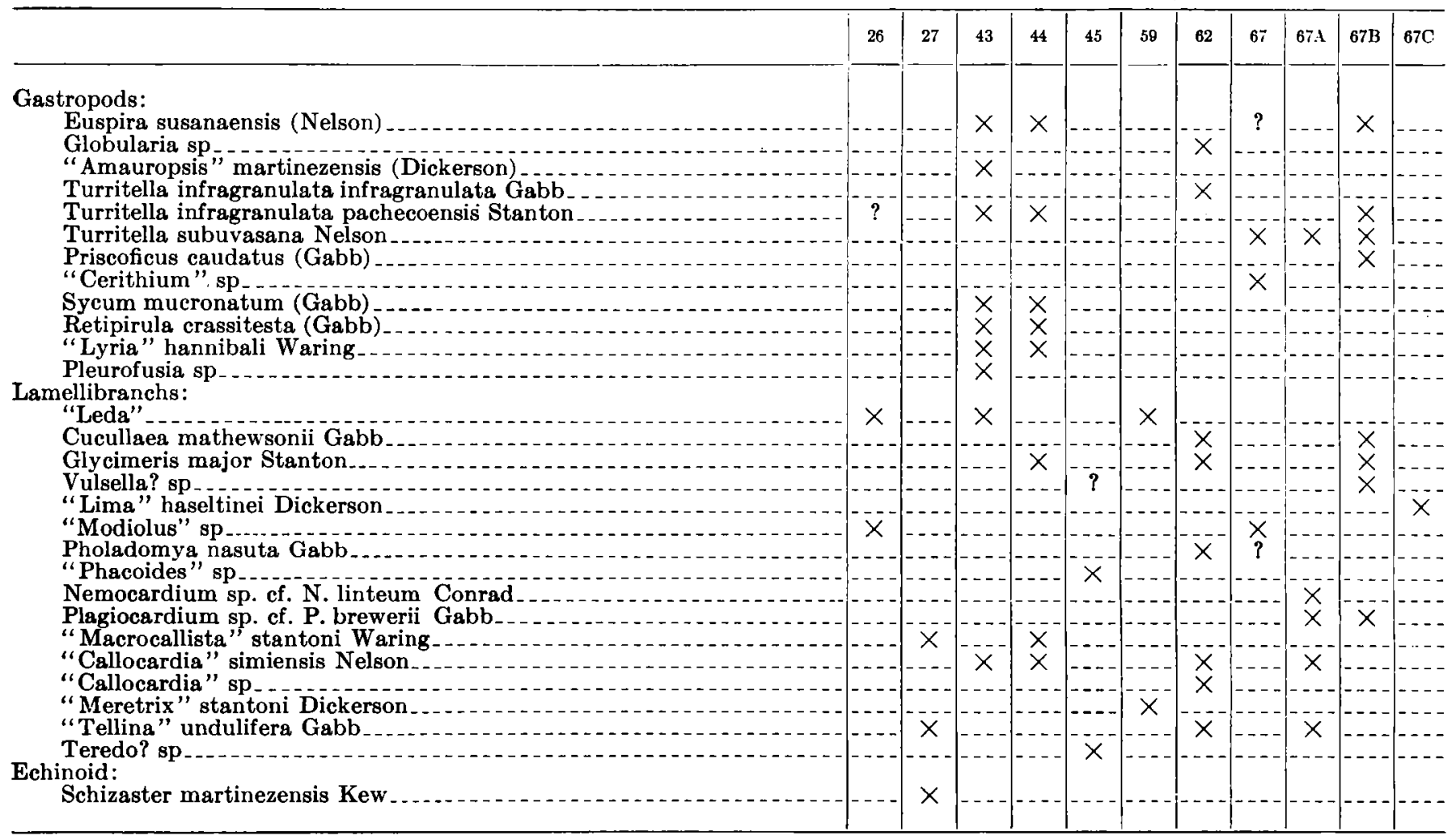

\section{ChICo AND MARTINEZ FORMATIONS OF THE TOPANGA CANYON} QUADRATGLR

A large tract in the southwestern part of the area covered by this report, mostly in the Topanga Canyon quadrangle, is covered by steeply dipping rocks of the Chico and Martinez formations. Because of the dense covering of brush and the apparent presence of unexposed structural complications, it has not been possible to differentiate these formations in this tract, at least within the time available for this investigation. Collections of fossils characteristic of the Chico and Martinez formations, together with a rather distinct difference in lithologic character, provide, however, a basis for a description of the probable approximate distribution of these formations.

Chico fossils have been collected in this undifferentiated area from localities $17,46,47,48,49$, and 54 . (See pp. 123-124 and pl. 16.) Examination of the geologic map will make clear the distribution of these localities and of reefs of the white algal limestone which are known to be present in the Martinez formation farther north and which have nowhere been found closely 
associated with Chico fossils or typical Chico rocks. Except for a single small reef of white algal limestone in the east wall of Topanga Canyon, all such reefs are restricted to that part of the Upper Cretaceous and Eocene area which is bounded on the west by lower Miocene rocks and the lower part of Santa Ynez Canyon, on the south by a west-southwestwardtrending fault across upper Pulga Canyon, on the east by the north-northwest fault that lies just west of Temescal Canyon, and on the north by a southwestward-trending fault near the head of Santa Ynez Canyon. The limestone reefs in this north-south elongated belt of dense brush and poor exposures are associated with rocks that consist largely of compact dark-gray, greenish-gray, and brown shale together with intercalated beds of greenish-gray and light-gray to brown sandstone, most of which are soft, thin, and of fine texture, although massive 50-foot beds of poorly sorted arkosic sandstone and conglomerate are present in upper Pulga Canyon. Fossils collected from this area at localities $43,44,45,59,67,67 \mathrm{~A}, 67 \mathrm{~B}$, and $67 \mathrm{C}^{22}$ and west of upper Pulga Canyon are listed in the table on page 92 and are considered by Woodring to be of Martinez age.

In the area adjoining the above-described area containing Martinez strata the Chico rocks are largely of strikingly different character, consisting in greater part of hard massive coarse brown conglomerate associated with dark gray shale and beds of hard gray sandstone which in places are highly fossiliferous. These beds are well exposed in Topanga, Santa Ynez, and Temescal Canyons. In Topanga Canyon the exposures are remarkably good, but here the Chico rocks are cut by numerous faults, so that interrupted sections of only small parts of this formation are exposed. The same is probably true to some extent of Santa Ynez Canyon, although the existence here of important faults in the Cretaceous rocks is difficult to prove. In Temescal Canyon and farther east there appears to be a continuous section of about 8,000 feet of southward-dipping Chico rocks, much the greater part of which is coarse brown cobblestone conglomerate like that along the highway in Topanga Canyon.

The cobblestone conglomerate of the Chico is the most remarkable feature of this formation. Its uniformity in the abundance and striking roundness of most of the cobbles and boulders, the existence everywhere of distinct bedding and a matrix of clean gray to greenish gray sandstone, and the presence here and there of marine fossils in associated beds of gray sandstone are features which support the belief that this conglomerate is marine, even though it and the associated beds appear to have a total thickness of 8,000 feet or more. Certainly none of it was laid down by streams on the land. A theory to account for its

2a Collection 67C, consisting of a giant "Lima," was contributed by J. H. Gilliland, and collection 67B by J. M. Tate, both of the Los Angeles Mountain Park Co. origin need not postulate any conditions strange to many parts of California in late geologic time; the presence of a continuously subsiding Chico basin of marine deposition adjoining a continuously rising land mass of strong relief appears to be all that is necessary.

Conglomerate similar lithologically to the conglomerate of the Chico but containing a large fossiliferous boulder which has yielded, according to $W . P$. Woodring, Mesalia martinezensis (Gabb) and a Turritella of Eocene aspect crops out in the west wall of lower Topanga Canyon about 2 miles below Topanga and about 50 feet north of a spring that is used extensively by the public. It seems apparent, therefore, that much of the older conglomerate in lower Topanga Canyon is Eocene or later and that some of the massive older conglomerate elsewhere in this district may be of Eocene age. Unless unexposed faults have complicated conditions, however, the 8,000 feet of conglomerate in and east of lower Temescal Canyon is Chico, because typical Chico fossils have been collected near the top of these beds at locality 49 . (See pl. 16.)

\section{OLIGOCENE (?) AND LOWER MIOCENE ROCKS}

SESPE (?) AND VAQUEROS (?) FORMATIONS

In the upper drainage area of Santa Ynez Canyon there is a thick unfossiliferous series of soft coarse red and light-gray to white arkosic sandstone and conglomerate which underlies, with apparent conformity, the massive brown fossiliferous sandstone of the lower part of the Topanga formation. Although these beds may actually be a part of the overlying Turitella ocoyana zone of southern California, they are herein tentatively considered to be older and equivalent to some part of the Sespe and Vaqueros formations, the latter corresponding to the Turritella inezana zone. It is doubtful whether rocks of Sespe age are actually present. In the adjoining area to the west, however, ${ }^{23}$ as well as elsewhere in southern California, rocks of red color underlying fossiliferous lower or middle Miocene strata have been mapped as Sespe. The writer does not believe that red color at about this stratigraphic position warrants correlation with the red Sespe formation at its type locality, some 20 miles north-northwest of the eastern part of the Santa Monica Mountains. In a transgressing or receding basin of deposition red color resulting from the same conditions may range through a considerable thickness. However, inasmuch as such red rocks commonly constitute a mappable unit and must be named, they may, in the absence of diagnostic fossils, be considered of questionable Sespe age and mapped as Sespe(?).

The total thickness of these rocks in the area south of the Topanga fault (see pl. 16) is approximately 4,000 feet but appears to vary between 3,500 and 4,500 feet.

\footnotetext{
${ }^{23}$ See U. S. Geol. Survey Bull. 753, pl. 1, 1924.
} 
Here the series is locally divisible into two membersa lower one consisting of about 2,500 feet of soft lightgray to white conglomeratic and granitic sandstone, and an upper one consisting of about 1,200 feet of equally soft conglomeratic sandstone which is distinctly red in greater part. The abrupt change in color between these two members is not, however, a consistent feature confined to one stratigraphic horizon; beds of both red and gray color pass laterally into each other, so that within a few thousand feet along the strike red conglomerates occur much lower in the section and most of the upper member is light gray.

South of the Topanga fault the contacts of these beds with adjoining Cretaceous and Eocene rocks are everywhere faulted, so that the depositional relation with the older rocks can not be determined. Two miles farther north, however, 1,800 to 2,000 feet of these beds conformably underlie the Topanga formation and overlie the Martinez formation with what appears to be considerable discordance in dip and strike. Their actual contact with the underlying Martinez shale was not observed, however, but attitudes of beds are very uniform throughout each individual formation, and the characteristic attitudes of one formation differ from those of the other by $30^{\circ}$ in strike and $20^{\circ}$ in amount of dip. (See pl. 16.)

Rocks similar to those described above but entircly of red color crop out in Topanga Canyon, where they are intruded by basalt and are in fault contact with the Topanga formation and with dark-gray shale of probable Chico age. (See pl. 30,C.) Along the southern edge of the mountains, just east of lower Topanga Canyon, these same soft red and gray conglomerates have a similar relation to overlying Topanga sandstone and are faulted against massive conglomerate of the Chico formation.

In the eastern part of the mountains, east of Stone Canyon, there is a variable thickness of unfossiliferous soft coarse gray conglomerate which rests direcily on the granite and conformably beneath fossiliferous beds of the Topanga formation. Because of the absence of fossil evidence as to the age of this conglomerate and the absence of much red color to support the possible contention that it is equivalent to some part of the Sespe and Vaqueros formations, this conglomerate is herein described as a lower member of the Topanga formation. ${ }^{24}$

\section{MIOCENE ROCKS}

\section{TOPANGA FORMATION (MIDDLE MHOCENE)}

The Topanga formation, although far from uniform in detail features, is as a whole of fairly consistent character throughout its extent in the eastern part of the Santa Monica Mountains. The formation

24 Mr. S. A. Crouch, of the University of Southern California, has reported to the writer the finding of a perfect pelecypod cast near the head of the first canyon east of Nichols Canyon, which Dr. A. J. Tieje has identified as Pecten andersoni. This meager fossil evidence is indicative of middle Miocene (Topanga) age. consists essentially of a thick, steeply dipping series of sandstone, conglomerate, and shale, together with a large amount of intrusive and extrusive basalt of Topanga age. (See pp. 95-96.) In most areas massive conglomeratic sandstone occurs in the lower part of the formation, associated with the basalt; this is generally overlain by a considerable thickness of thinbedded shale and sandstone, locally intercalated with more massive beds of sandstone. In some areas the highest exposed part of the formation, stratigraphically above the thin-bedded shale and sandstone, is characterized by another series of massive sandstone with shale.

AREA BETWEEN STONE CANYON AND CAHUENGA FAULT

The Topanga formation is the most extensive largely sedimentary formation in the easternmost part. of the Santa Monica Mountains, north of Hollywood and Beverly Hills. Much of the lower part of the formation, composed of massive beds of sandstone and basalt, is well exposed along Cahuenga Avenue, just south of Cahuenga Pass, and outcrops of practically the entire formation may be studied along a. series of new street cuts east and west of the pass. In the area between Stone Canyon, north of Sawtelle, and the Cahuenga fault (see pl. 16) rocks herein described as belonging to the Topanga formation rest. directly upon the Mesozoic granitic and metamorphic rocks that form the core of this part of the range. Freshly cut exposures of this contact at several places, together with its generally irregular character, definitely show that it is depositional throughout much of its extent. As is shown on the geologic map, however, the contact in most of the area between Brown Canyon and Laurel Canyon is faulted.

The Topanga formation in this area is divisible into three rather distinct members-a lower one that consists essentially of soft coarse gray conglomerate and loose granitic sandstone; a middle one composed of massive, more indurated beds of brown conglomerate and fossiliferous sandstone associated with minor amounts of gray shale and a thick body of basalt of both intrusive and extrusive origin; and an upper, less resistant member that consists essentially of soft thinbedded shale and sandstone but contains a few massive ledges of brown conglomerate sandstone. These subdivisions are particularly distinct in that part of the area crossed by structure section line $\mathrm{I}^{-\mathrm{I}^{\prime}}$ (see pl. 17), and their distribution is indicated on the geologic map.

Lower conglomerate member. - The lower member, of coarse detrital character, was derived in part from the granitic and metamorphic core of the range and was deposited upon its irregular surface. Largely because of the preexisting irregularities of this old surface this conglomerate member varies considerably in thickness; east of Nichols Canyon and west of Laurel Canyon it is as much as 1,500 feet thick, but at an intervening. 


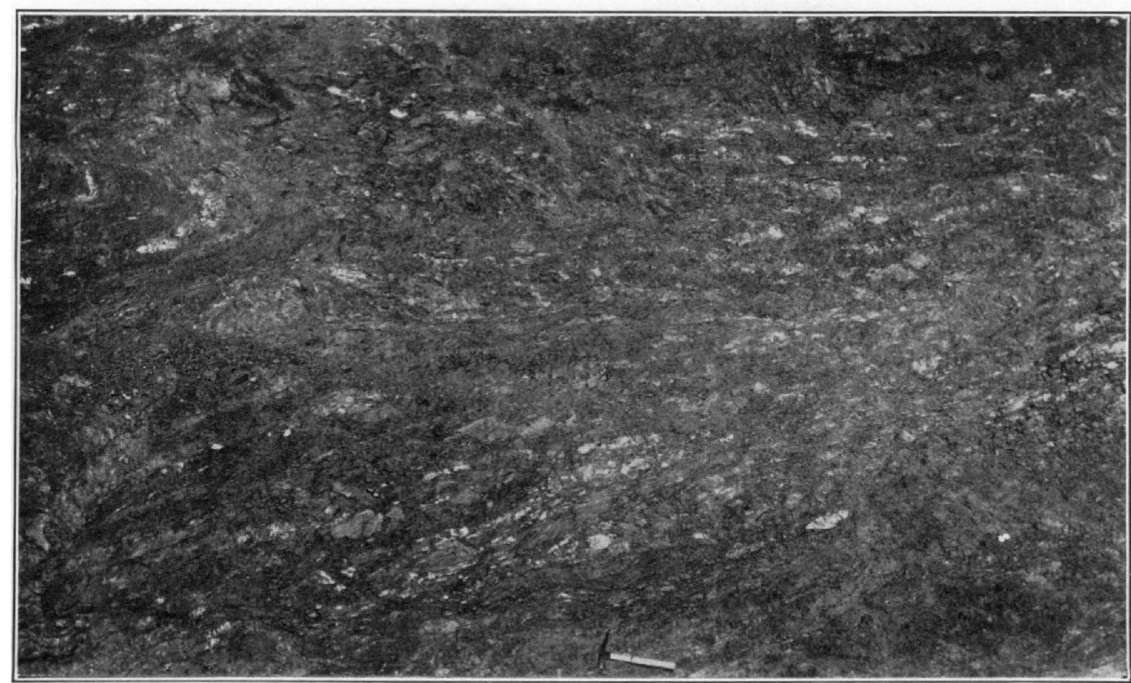

A. DISTORTED SCHIST, SLATE, AND PHYLLITE OF SANTA MONICA SLATE EAST OF COLDWATER CANYON, CALIF.

Shows tho mumerous voins of white quarl\%.

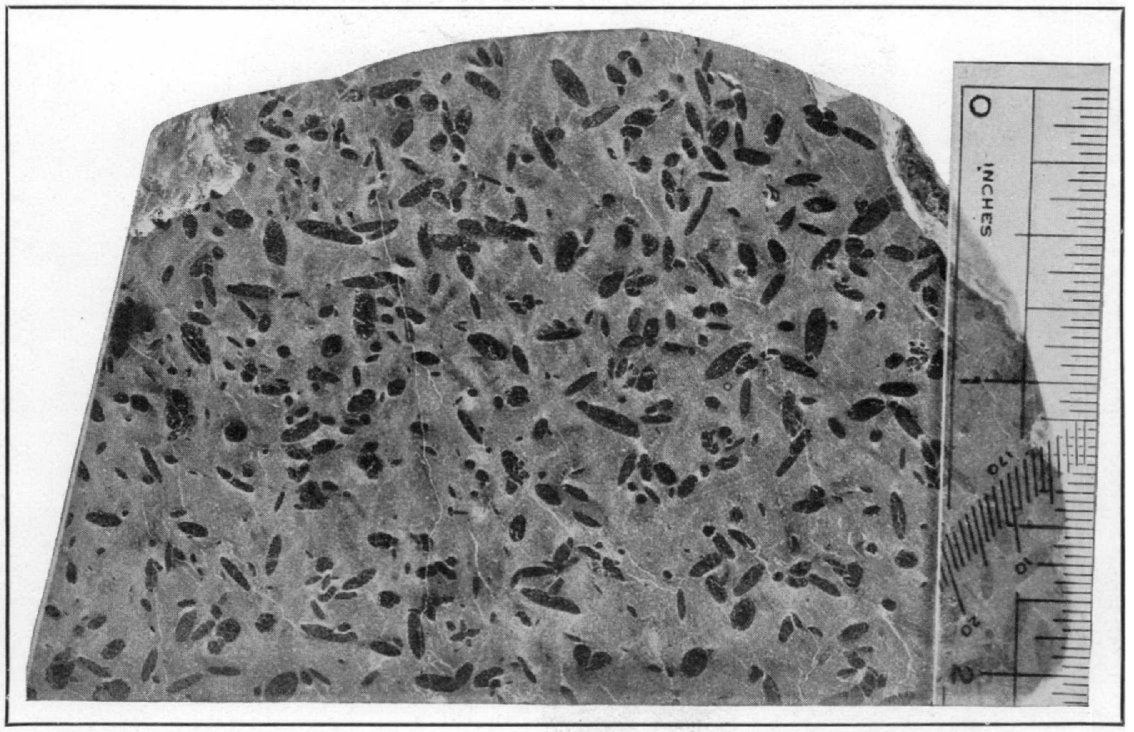

B. HAND SPECIMEN OF SPOTTED SLATE FROM SEPULVEDA CANYON, CALIF. Photograph by K. E. Lohman.

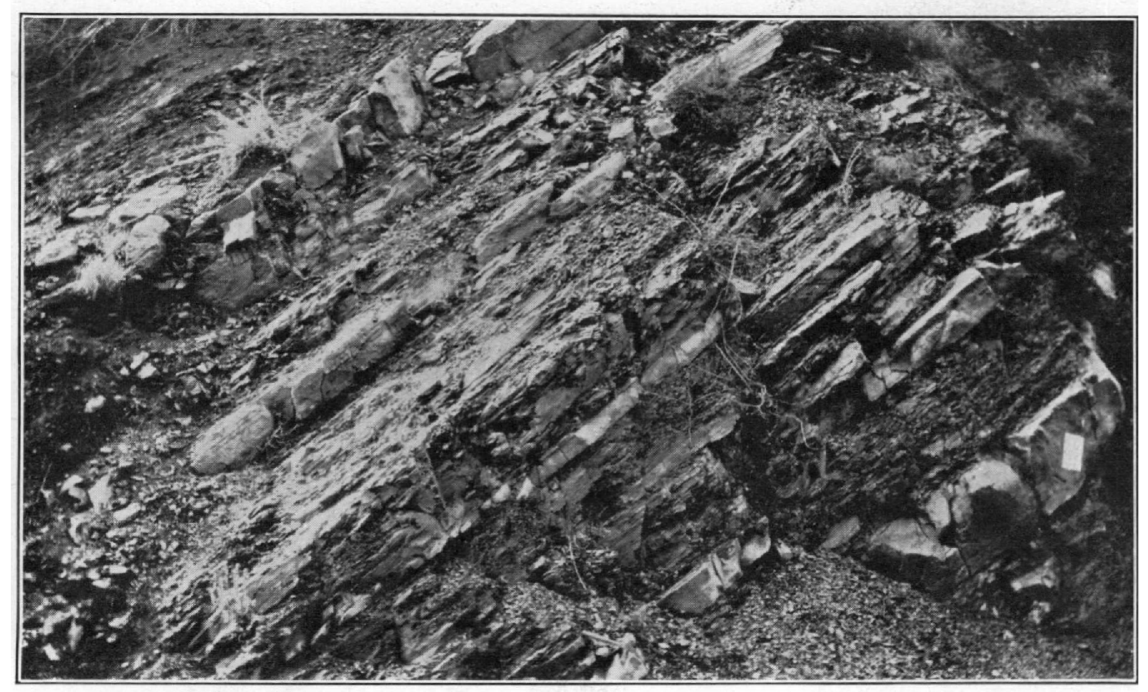

C. THIN-BEDDED HARD BLACK SHALE AND GRAY SANDSTONE OF CHICO FORMATION IN TOPANGA CANYON, CALIF. 


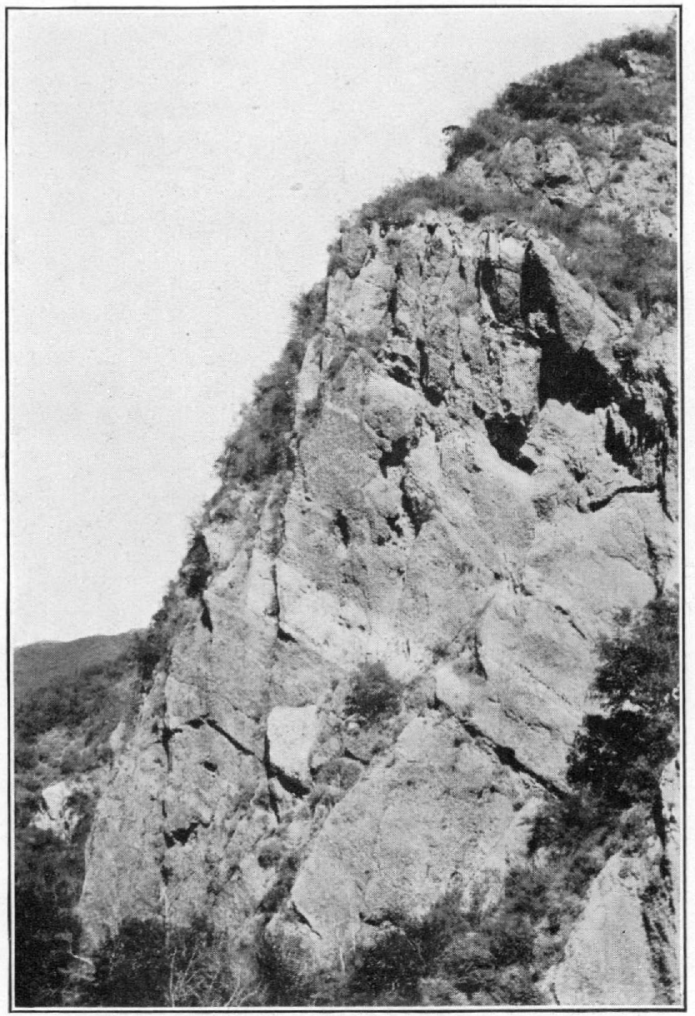

A. MASSIVE CONGLOMERATE OF CHICO FORMATION IN TOPANGA CANYON, CALIF.

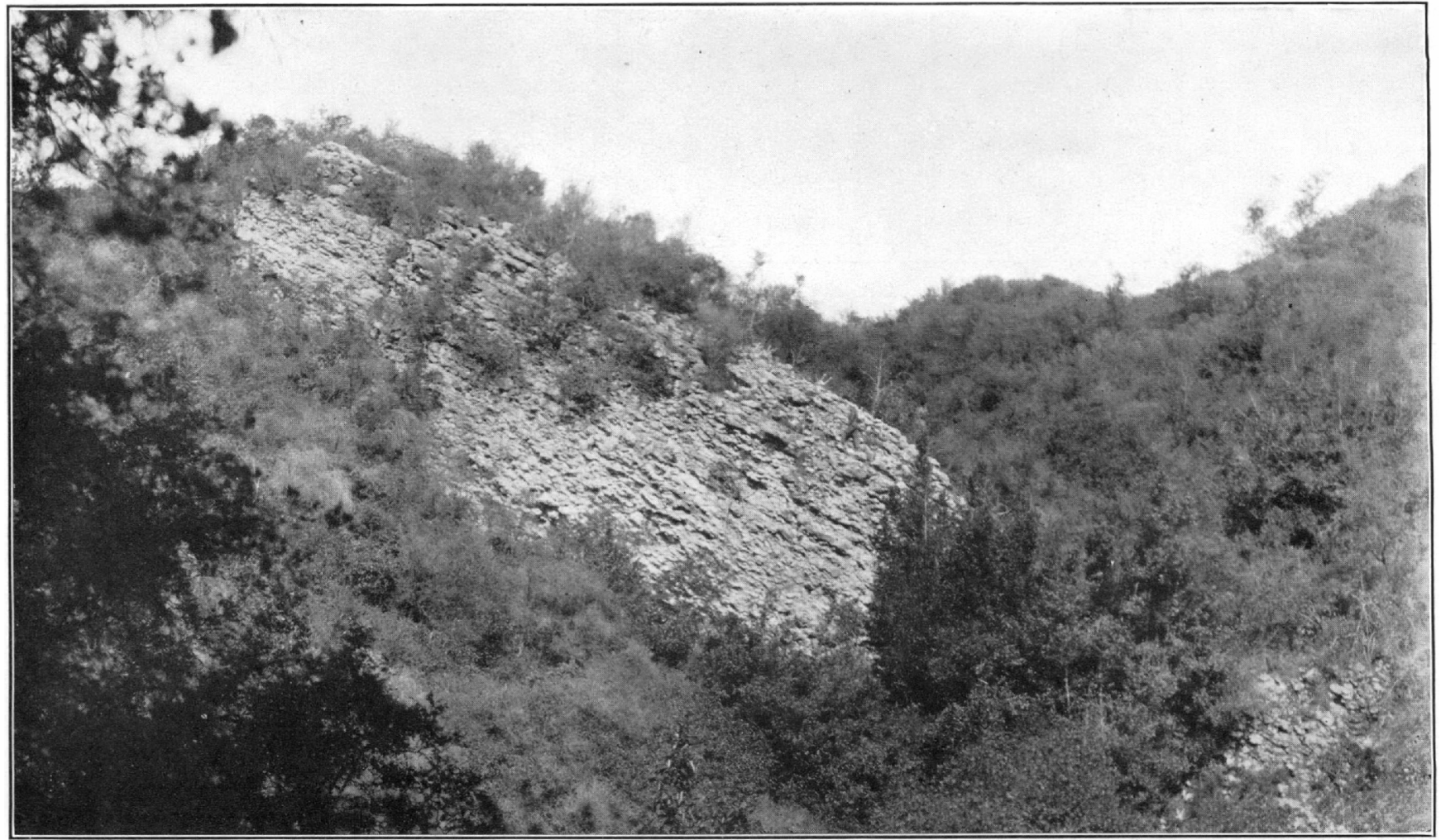

B. LEDGE OF WHITE ALGAL LIMESTONE OF MARTINEZ AGE

Limestone is about 40 feet thick. Photograph reproduced by courtesy of J. H. Gilliland, Los Angeles Mountain Park Co. 


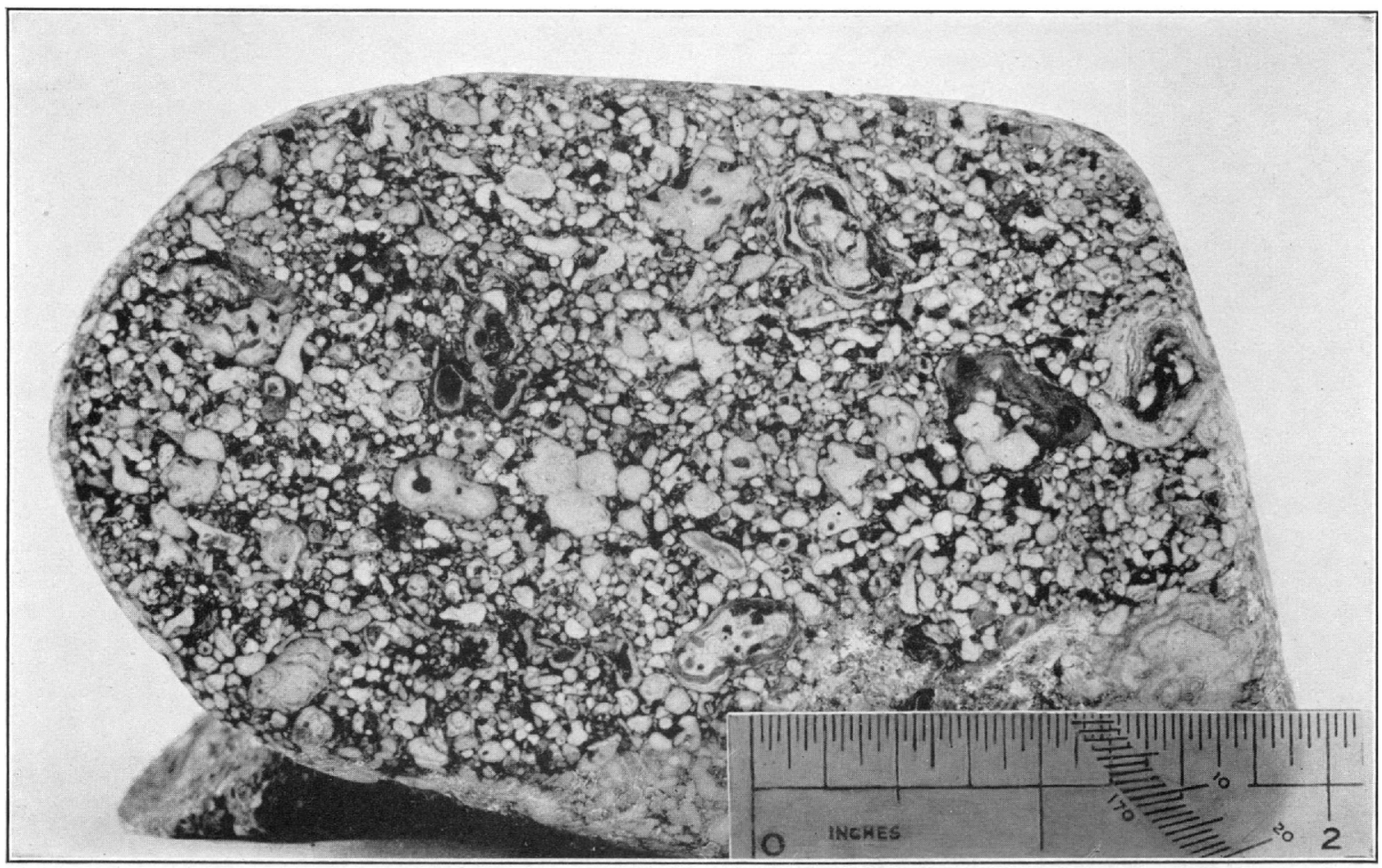

A. IIAND SIECIMEN OF LIGHT-GRAY ALGAL LIMESTONE OF MARTINE7 AGE, FROM LARGE REEF AT LIMLSTONE OUARAY IN UPPIER SANTA YNIZZ CANYON, CALIE.

Pholorriph by K. l:. Luhman

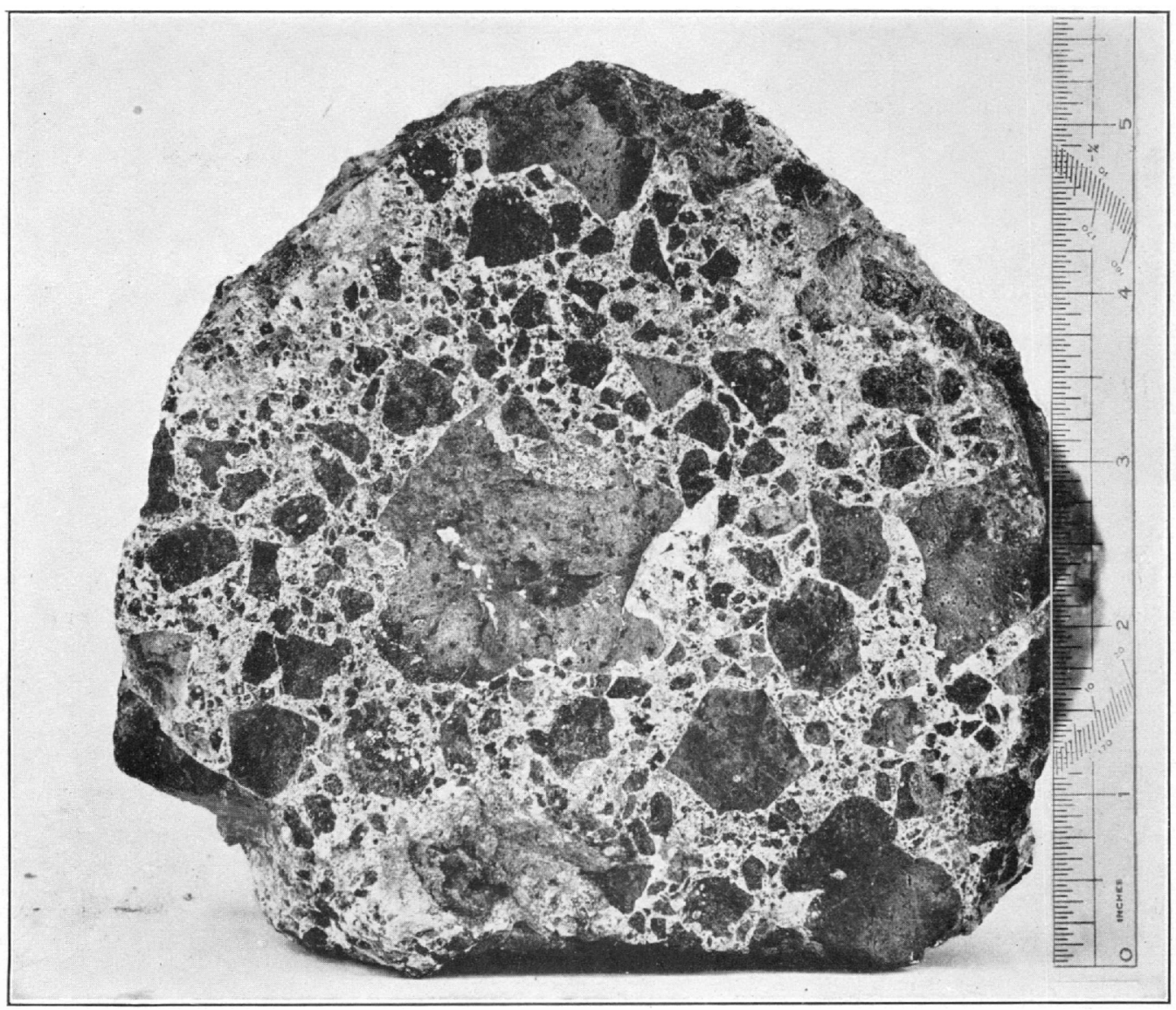

B. HAND SPECIMEN OF VOLCANIC AGGLOMEHATE FHOM TOPANGA FOHMATION AT INTERSECTION OF MULHOLLAND HIGIIWAY WITI LAIIREL CANYON HOAD

Pholorraph by K. E. Lohman. 


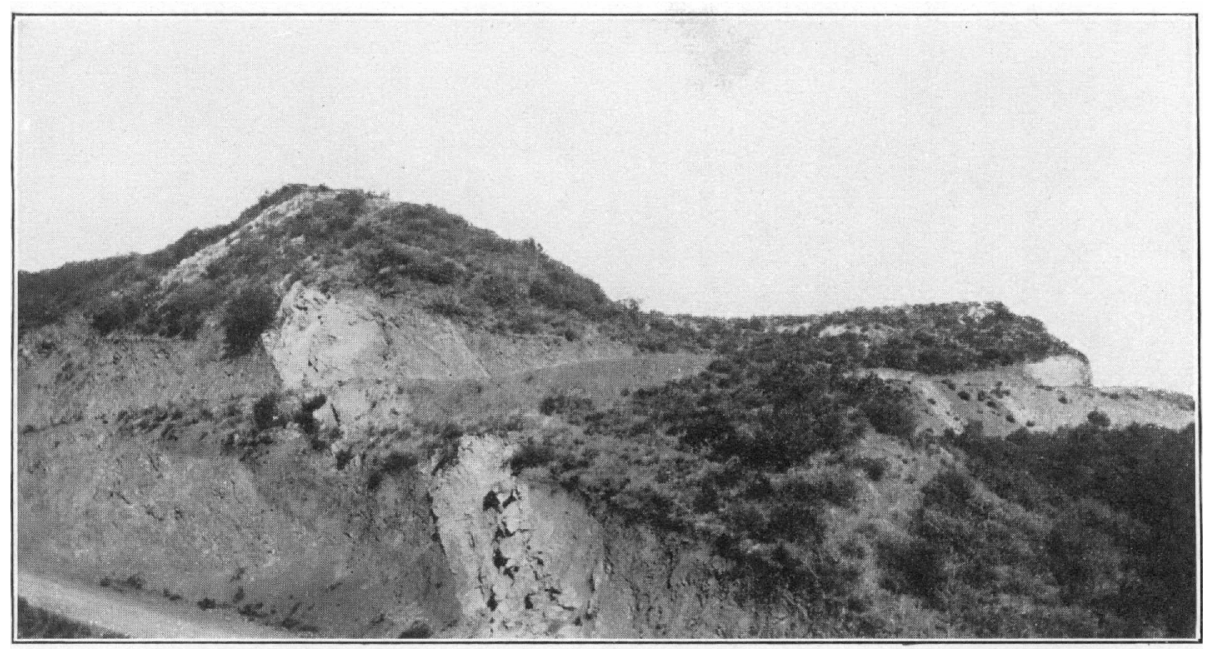

A. INTRUSIVE BASALT WITH SANDSTONE STRINGFRS OF TOPANGA FORMATION View along Mulholland Ilighway just west of Cahuenga l'ass, Calif.

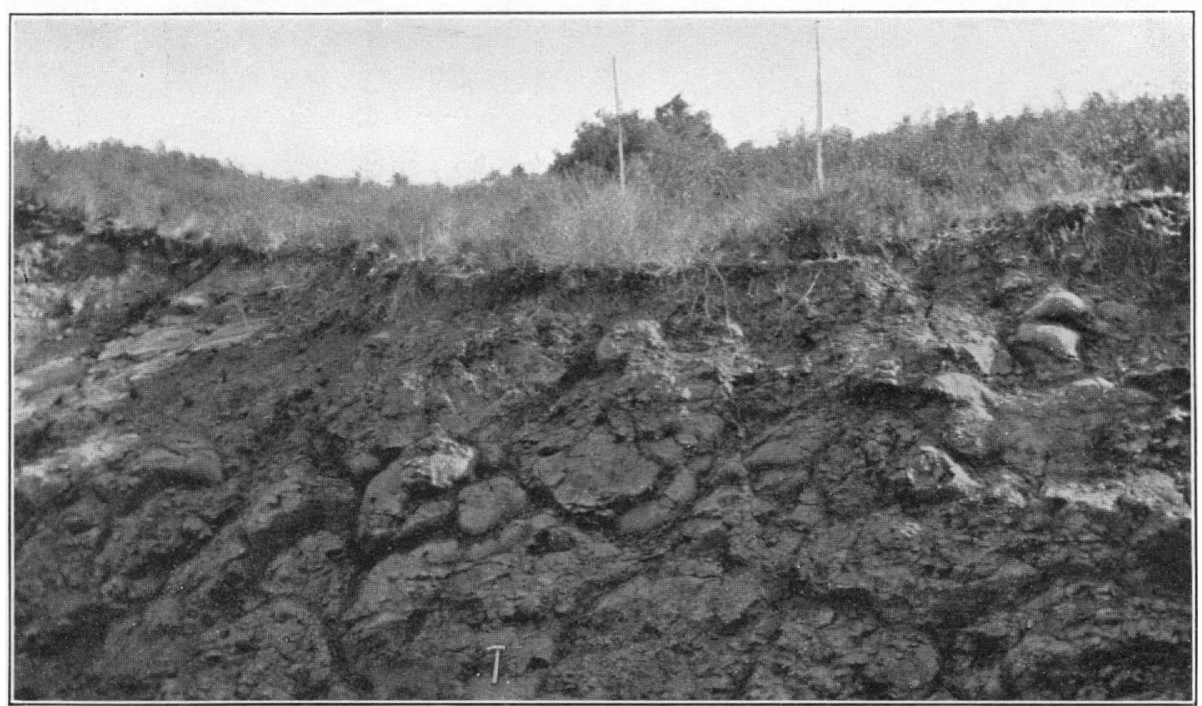

B. PILLOW STRUCTURE IN UPPER PART OF BASALT EAST OF LAUREL CANYON ROAD

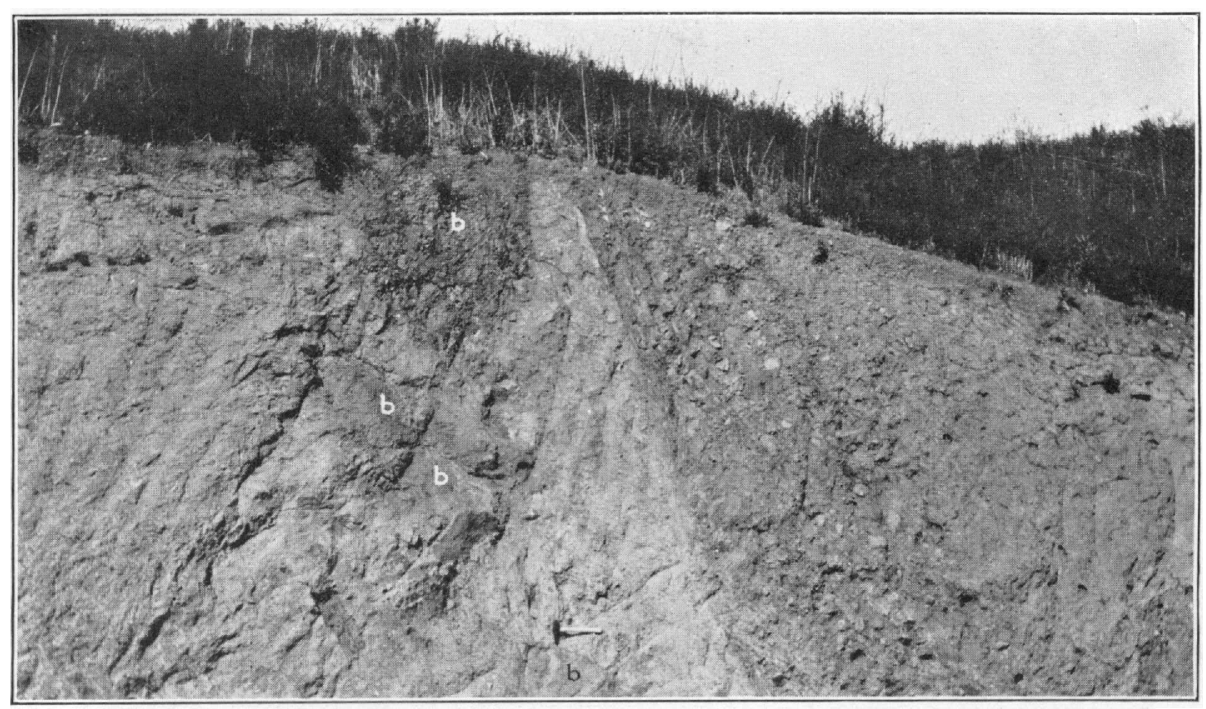

C. CONGLOMERATE OF TOPANGA FOHMATION Cut near intersection of Mulholland Highway and Woodrow Wilson Drive. Shows large weathered boulders of 
point at the head of Laurel Canyon it thins to about 250 feet. Except for the local occurrence of a basal red conglomerate which is generally only a few feet thick but which in the depression in the granite surface east of Nichols Canyon is about 200 feet thick, this member is fairly uniform throughout and consists of a mass of soft light-colored granitic and arkosic sandstone with abundant embedded cobbles and boulders as much as 1 foot in diameter. These cobbles and boulders are commonly very well rounded and have a strikingly smooth and highly polished surface. For the most part they are very hard and consist in about equal proportions of granite and gneissic granite, hard dense porphyritic basalt and andesite, and clear varicolored quartzite of fine uniform texture. The matrix of the conglomerate is similar to the associated sandstone, and, though clean and free from clayey materia], is composed of angular and subangular mineral and rock fragments poorly sorted as to size. Bedding throughout this member is commonly lenticular and indistinct.

Identified heavy minerals associated with the abundant quartz and orthoclase and plagioclase feldspar in samples examined are, in order of abundance, leucoxene ilmenite, epidote, garnet, titanite, zircon, glauconite, and tourmaline. Amphiboles appear to be absent. This mineralogic character is in sharp contrast to that of the San Onofre breccia (middle Miocene) of coastal areas 20 to 40 miles farther west ${ }^{25}$ and near San Onofre, 70 miles to the south. ${ }^{26}$

A prominent bed of coarse white granitic sandstone and conglomerate marks the top of this member and can be traced through practically the entire extent of this area. (See footnote 24, p. 94.)

Middle conglomeratic sandstone and basalt member.Along structure section line $\mathrm{I}^{-\mathrm{I}^{\prime}}(\mathrm{pls} .16,17)$ the middle member of massive sedimentary and basic igneous rocks has a total thickness of 3,000 feet, of which about 1,600 feet is massive brown conglomeratic sandstone with a minor amount of thin-bedded sandstone and shale. From 100 to 1,000 feet of this massive brown conglomeratic sandstone, which is locally fossiliferous, occurs at the base of this member and is overlain by a prominent elongate body of basalt which is far from uniform in thickness and which lenses out toward the west, near the head of Franklin Canyon. Basalt is to be found in small areas and narrow bands still farther west at about this same stratigraphic horizon, but its occurrence is very sporadic. Just east of the head of Nichols Canyon the basalt is overlain by about 1,300 feet of massive coarse sandstone and conglomerate, together with a subordinate amount of thinbedded sandstone and shale. The upper part of this largely massive unit grades westward into finer and thinner bedded shale and sandstone, so that the con-

${ }^{25}$ Woodford, A. O., and Bailey, T. L., Northwestern continuation of the San Onofre breccia: California Univ. Dept. Geol. Sci. Bull., vol. 17, p. 190, 1928.

${ }_{20}$ Woodford, A. O., The San Onofre breccia, its nature and origin: Idem, vol. 15, pp. 159-280, 1925

$$
4176^{\circ}-31-2
$$

tact between this middle member and the overlying less massive upper member (represented on the geologic map by the discontinuous dashed line) is difficult to draw in the more western area, south and southwest of Universal City. A few hundred feet above the basalt, both east and west of the Laurel Canyon road, massive conglomerate sandstone is associated with thin discontinuous beds of hard white opal shale, much like that which is so common in the lower part of the overlying Modelo formation.

One of the most significant features of the conglomeratic portion of this middle member is the striking difference between the boulders present in beds below the basalt and those characteristic of much of the 500 to 700 feet of beds which directly overlie the basalt. In the lower beds the cobbles and boulders are generally well rounded and, like those of the underlying conglomerate, consist essentially of granite, granodiorite, dense andesite and basalt porphyry, and quartzites of various color. In the beds above the basalt, the most striking feature is the abundance of deeply weathered subangular boulders of basalt as large as 4 feet across (see pl. 21, C); in outcrops where only 10 feet of a bed is exposed it is not uncommon to find six or eight basalt boulders that average 1 foot in diameter. The basalt composing these soft boulders is in striking contrast to the dense porphyry of the hard, highly polished boulders in beds stratigraphically lower but is identical with that of the large basalt mass directly below. Inasmuch as such boulders do not occur at any point below the basalt, their abundance in beds that directly overlie it is accepted as very good evidence that this large basalt mass in the lower part of the Topanga formation underwent erosion in some part of the mountains directly after it was formed and was the source for much of the sediment in directly overlying beds. This formation is easily accessible in road cuts near the head of Nichols Canyon and farther west where the Mulholland Highway crosses beds that directly overlie the basalt. Corroborative evidence of this relation is found in the fact that in suites of sandstone saniples collected through the Topanga formation, from the base upward, green hornblende makes its first appearance in samples collected above the basalt, at the lowest horizon where basalt boulders are present.

The geologic map clearly illustrates the fact that virtually all of the basalt in the area between Stone Canyon and the Cahuenga fault is confined to one general stratigraphic position in the lower part of the Topanga formation. This relation suggests that the major part of the basalt may be extrusive and of lower Topanga age, having accumulated before, not after, the upper part of the Topanga formation. As is discussed below, this appears to be true in part for much of the basalt, particularly in the area west of the long diagonal east-northeast fault that cuts across 
Cahuenga Pass and sec. 33, T. 1 N., R. 14 W. East of this fault the tonguelike projections in the upper part of the basalt body and the presence of contactmetamorphic rock along the base of overlying sandstone prove conclusively that the upper portion of the basalt in this more eastern area is intrusive. It is believed that this upper part of the basalt east of the fault is the result of a distinctly later period of igneous activity in late Topanga or even more recent geologic time, and that this later basalt intrusion may well have caused in this area pronounced increase in the fault displacements of beds that overlie the basalt. (See on pl. 16 the relative displacements of the sandstone stringer in the midst of the basalt mass and the dashed line representing the base of the overlying upper member of the Topanga formation.) The same result could, of course, have been produced by rotational movement along this vertical fault, but the close relationship between major pre-Modelo structural deformation and basalt intrusions in the TopangaGarrapata Canyon area, farther west, is established and may apply as well for the easternmost part of the mountains.

The lower part of the basalt is well exposed on the road just south of the Mulholland Highway in the center of the north edge of sec. 4, T. 1 S., R. 14 W., and farther west at the intersection of the Mulholland Highway with the Laurel Canyon road. At both of these localities the lower part of the basalt is distinctly pyroclastic and consists almost entirely of very angular fragments of basic volcanic rock of varying color and texture embedded in a light-gray carbonate matrix. (See pl. 20,B.) Most of the rock fragments are dense and finely crystalline, though some are vesicular, and others of distinctly glassy character are common. At the intersection of the Mulholland Highway with the Laurel Canyon road this pyroclastic character is associated with pronounced bedding in this extrusive rock. These characteristics are in accord with the absence of baking along the top of the underlying shale.

The definitely pyroclastic lower portion of the basalt is overlain by a nearly black dense rock which in fresh cuts shows a mass of angular blocks and gives the impression of having once been a solid rock of uniform character that is now thoroughly shattered. The angular blocks protrude from the surface of the outcrops and are separated by soft, much weathered interstitial substance, apparently of the same basaltic composition. This portion of the basalt appears to be a typical autoclastic rock which has assumed its fragmental nature subsequent to igneous activity, possibly as a result of the combined effects of cooling and structural deformation.

Much of the upper half of the basalt has a striking pillow structure (see pl. $21, B$ ); other parts are vesicular and amygdaloidal, with amygdules of calcite and the zeolites. Some amygdules from basalt on the Mulholland Highway near Cahuenga Pass have been found to be of the mineral thomsonite. ${ }^{33}$

Locally the uppermost part of the basaltic rock contains casts of fossil shells and is of sedimentary origin, having resulted from the reworking of the upper part of the underlying basalt. Observed occurrences of this sort are found west of the diagonal fault across sec. 33, T. 1 N., R. $14 \mathrm{~W}$., in the area where the base of the overlying sandstone serjes is not baked and where the lower few hundred feet of this overlying marine series contains abundant basalt boulders eroded from some part of the basalt mass just described.

By way of summary it may be said that much of the basalt in the area between Stone Canyon and the Cahuenga fault is extrusive and of lower Topanga age, but that some of it is definitely intrusive and considerably younger, possibly of upper Topanga age. That part of the major basalt mass which is unquestionably intrusive lies east of the diagonal fault in sec. 33 and forms the upper third of this mass. Farther west the major mass contains extrusive rock in its lower portion and has relations with overlying strata which strongly suggest that its upper part is also extrusive. Some features, however, particularly the method by which this mass terminates to the west, indicate that part of it is intrusive. It seems certain that the mass is in part extrusive and in part intrusive and that it was uplifted and subjected to erosion shortly after it was formed.

Upper thin-bedded shale and sandstone member.-The middle member of massive conglomeratic sandstone and basalt of the Topanga formation is overlain by an upper member which, along the line of structure section I-I' (pls. 16, 17), has an exposed thickness of 2,800 to 3,000 feet. This member is well exposed in street cuts southwest and northeast of Cahuenga Avenue and is composed, to a large extent, of soft thin-bedded brown and bluish-gray shale and finegrained sandstone, although massive beds of soft brown and gray sandstone and conglomeratic sandstone also occur in the middle and upper parts, northeast of Cahuenga Avenue. The lower 1,500 feet is made up almost entirely of thin-bedded shale and sandstone and in much of the area is in striking contrast to the massive and more resistant conglomeratic sandstone of the underlying member. The contact between these two members is represented by the discontinuous dashed line shown on the geologic map. The lower part of the upper member is broken by the diagonal fault that cuts across Cahuenga Pass, and the upper part is folded into a rather sharp syncline along and

33 James Gilluly, of the Geological Survey, materially assisted the writer in the determination of this mineral, which, in this locality, has higher indices of refraction than those given in reference tables and textbooks, $a$ and $\beta$ both being 1.52+. For optical properties of thomsonite see Wherry, E. T., Am. Mineralogist, vol. 8, No. 7, p. 124, 1923. For other petrographic characteristics of the basalt see Schürmann, H. M. E., Beitrag zur Petrographie der Hollywood Hills (Santa Monica-Gebirge) bei Los Angeles: Centralbl. Mineralogie, 1928, Abt. A, pp, 7-13. 
west of Dark Canyon and, farther east along the Cahuenga fault, abuts abruptly against massive sandstone and conglomerate of the middle member of the Topanga formation.

A single small intrusive mass of basalt occurs in the upper part of this member and crops out on one of the hilltops southeast of Universal City.

HOLLY WOODLAND-GRIFFITH PARK AREA EAST OF CAHUENGA FAULT

Because of numerous structural complications the area east of the Cahuenga fault is the most difficult area in the eastern part of the Santa Monica Mountains to interpret correctly. Irregularly distributed bodies of basalt are intruded into and faulted against granite at numerous places, and both the basalt and the granite are in turn in fault contact with sedimentary rocks that belong at various stratigraphic horizons from the bottom to the top of the Topanga formation.

Except for the widespread occurrence of Jurassic (?) granite and a single down-faulted area of the Modelo formation at the east end of the mountains, all the rocks east of the Cahuenga fault are of Topanga age. The only part of this area in which a continuous and fairly complete section of much of the Topanga formation is exposed occupies the irregular fault block due east of Cahuenga Peak and directly south of the granite mass that forms the northeastern point of the mountains. Good outcrops of much of this section may be examined along the Griffith Park Road leading north from the crest, but the ridge tops east and west of the road offer the best exposures of the massive conglomeratic sandstone in the lower part of the section. Although this section is not so thick and is without a distinct lower conglomerate member, it is much like the above-described section west of the Cahuenga fault, both as to character and as to sequence of formational members. The lower member, which corresponds to the middle member of the area farther west, is characterized by massive beds of brown and gray conglomeratic sandstone which locally contain marine fossils and are associated with basalt of both intrusive and extrusive origin.

The intrusive character of some of the basalt is evident from the presence of dikelike masses that cut across beds of sandstone. The extrusive facies of the basalt is well exposed in the upper part of the westernmost and stratigraphically highest basalt mass east of Cahuenga Peak. This mass contains about 150 feet below its top a prominent resistant ledge of brick-red color which is overlain by soft basaltic material with distinct bedding that appears to be of detrital character and to have been in part water-laid. The water-laid beds, which are commonly only a few inches thick, are associated with equally thin zones that have characteristics of flow breccias, being composed of alternating beds of dense spheroidal basalt and basalt breccia.
Material of this same type occurs in the upper part of the basalt exposed along the Griffith Park Road 2,500 feet due south of the summit and at another point on the same road due east of the basalt quarry in Brush Canyon. At the former locality the overlying conglomeratic sandstone, as would be expected, is not metamorphosed and contains innumerable small fragments of basalt.

North of the summit in the fault block east of Cahuenga Peak the basalt and massive conglomeratic sandstone are overlain by a few hundred feet of soft coarse conglomerate with abundant boulders of granite, quartzite, and basalt, the basalt having been eroded from the underlying basalt of lower Topanga age. The contact of this conglomerate with the overlying thin-bedded brown and bluish-gray shale and sandstone, in this area as well as along the southern edge of the mountain, is shown on the geologic map by a dashed line. This upper member, which is very similar to the upper member of the Topanga formation west of the Cahuenga fault, is flexed into a series of sharp folds and, together with the underlying conglomerate, is faulted against the granite mass that forms the northeastern part of the hills.

The Cahuenga Peak fault block is composed of a northward-dipping series of poorly consolidated brown and gray conglomerate which grades upward into massive, fairly well cemented beds of coarse brown sandstone. The lower strikingly conglomeratic part of this series crops out on the south slope of Cahuenga Peak and in street cuts of Hollywoodland west of Brush Canyon. It is simply a mass of rounded to subangular boulders and cobbles embedded in a soft matrix of coarse arkosic sandstone. It appears to be uniform in composition throughout, the boulders and cobbles being composed of granite, granodiorite, quartzite, basic porphyry, and basalt. The boulders of basalt, which invariably are deeply weathered and very soft, are abundant at many horizons throughout this conglomeratic member and have undoubtedly been derived by subaerial erosion from the basalt series in the lower part of the Topanga formation. The presence of these abundant basalt boulders in the conglomerate of the Cahuenga Peak fault block is the only evidence found to be useful in determining the position of these rocks within the Topanga formation, but inasmuch as the occurrence of such boulders is restricted to a distinct stratigraphic zone above the basalt in other areas where more complete sections are exposed, this petrographic evidence of age is considered to be conclusive. This conglomerate is therefore regarded as younger than the basalt series of the lower part of the Topanga and equivalent, in part at least, to the similar basalt-boulder conglomerate that directly overlies the basalt series in areas east and west of Cahuenga Peak. In the Cahuenga Peak area, however, this conglomerate appears to have a thickness of 
3,000 feet or more, which is in sharp contrast to the few hundred feet of this conglomerate on adjoining fault blocks east and west of Cahuenga Peak. Either the great thickness of this conglomerate south of Cahuenga Peak is more apparent than real, owing to the possible presence of unmapped strike faults that have resulted in repetitions of strata, or the Cahuenga fault block during middle Topanga time was a subsiding basin of relatively rapid deposition which, after the lower Topanga period of igneous activity, adjoined rising land areas of granite, basalt, and lower Topanga conglomeratic sandstone. The latter alternative is considered to account best for the remarkable thickness of this conglomerate. Although it is possible that faulting has increased the apparent thickness somewhat, it is unlikely that such faulting would have resulted in so notable a thickening without exposing either underlying or overlying members of the Topanga formation.

In view of the presence of poorly preserved marine fossils in the upper part of this member and the absence of clay in the clean sandstone matrix of all parts of it, this conglomerate is considered to be largely or entirely of marine origin.

Fossils collected from locality 53, between Cahuenga Peak and the Griffith Park Road, are listed on page 100.

AREA NEAR ENCINO RESERVOIR

The Encino Reservoir is on the north flank of the Santa Monica Mountains, near Encino Park, and is surrounded by coarse, poorly consolidated conglomerate and conglomeratic sandstone, which in its lower portion contains considerable poorly exposed basalt, largely of intrusive origin. The conglomerate has a maximum exposed thickness of 3,500 to 4,000 feet and is probably equivalent, in part at least, to the middle member of the Topanga formation exposed farther east, in the area between Stone Canyon and the Cahuenga fault. It is overlain unconformably by the Modelo (upper Miocene) formation, a relation which is very evident on the ridge west of the Encino Reservoir and which is well exposed in a cut along an old abandoned road 2,700 feet east of the east end of the dam. The discordance in dip of the two formations in actual contact at this road cut is $20^{\circ}$, beds of the Topanga formation dipping the more steeply.

The conglomerate of the Topanga formation in this area is brown and gray and contains cobbles and boulders that average 3 to 5 inches in diameter but attain a maximum size of more than 12 inches. Boulders of light-gray granite are not common and are associated with others of quartzite and varicolored porphyry, together with subangular chunks of gray shale as much as 15 inches across which have probably been eroded from the underlying Martinez or Chico formations.
Fossils collected from localities 13 and 14, east of the Encino Reservoir, are listed in the table on page 100.

TOPANGA-GARRAPATA CANYON AREA

All rocks of pre-Modelo age in the vicinity of Topanga and Garrapata Canyons, along the western edge of the area covered by this report, are steeply tilted, broken by many faults, and intruded by basalt and diabase. For the most part, rocks of the Topanga formation in this area lie north of the Topanga fault and west of the Santa Ynez fault (see pl. 16) and dip in a westerly direction away from the uplifted anticlinical area of old slate farther east.

Only a partial section of the entire formation is exposed in this area, but it includes about 3,000 feet of massive brown sandstone, conglomerate, and gray shale. Although the presence of basalt intrusions makes it difficult even to estimate normal sedimentary rock thicknesses, there appears to be 1,250 to 1,500 feet of massive hard marine conglomeratic sandstone, which occupies the lower part of the formation and rests conformably upon much softer red and gray conglomerate of the Sespe (?) and Vaqueros (?) formations. These massive lower Topanga beds contain marine fossils and have been intruded by large bodies of basic magma, now exposed as light-gray to black diabase and coarsely crystalline basalt. Directly above this lower sandstone member is several hundred feet, possibly as much as 1,000 feet, of dark-gray shale which contains scattered yellow-weathering limestone concretions and beds of soft gray sandstone of fine texture. Beds of sandstone become more abundant and are thicker and coarser toward the top of the formation; the shale member grades upward into a higher arenaceous member which is exposed along much of the Garrapata Canyon road south of Mohn Springs and consists for the most part of soft thin-bedded to massive sandstone and conglomeratic sandstone with partings and thin beds of soft gray shale.

South of Topanga post office and the Topanga fault only the lower massive conglomeratic sandstone member of the Topanga formation is exposed.

At least a part of the basalt intruded into the Topanga formation of this area appears to be younger than the basalt of the lower Topanga near Cahuenga Pass and is probably equivalent in age to the intrusive late Topanga basalt of the Cahuenga Pass area. Irregular intrusive bodies occur through practically all the exposed 3,000 feet of the Topanga formation, many of them having a distribution which apparently has been controlled by post-Topanga faulting. It seems fairly certain that at least a part of the basalt in the Topanga-Garrapata Canyon area was intruded near the end of Topanga time, probably during the period of pronounced pre-Modelo disturbance, and that faulting and basalt intrusion had a close genetic 
relation. (See pl. 16.) Elongate basalt bodies and at least one major fault pass beneath, not into, the base of the Modelo formation near Mohn Springs, although post-Modelo uplift of one basalt mass, which may occupy a fault zone now obscured by the basalt, apparently has been the cause of a small anticline in the overlying Modelo.

The unconformable relation between the Topanga and Modelo formations is one of the most remarkable geologic features of this area. It is best observed at fossil locality 20 , on the ridge near the east edge of sec. 32, T. 1 N., R. 16 W., and on the Garrapata Canyon road at Mohn Springs Cafe. (See pl. 22, B.)

Fossils collected at localities 25, 28, 32, 33, 34, 56, and 63 in the Topanga formation of this area are listed in the table on page 100.

That part of the Topanga formation exposed farther south along the coast consists almost entirely of massive brown conglomeratic sandstone which overlies red conglomerate and sandstone of the Sespe (?) and Vaqueros (?) formations and which is in fault contact with rocks ranging in age from Upper Cretaceous to upper Miocene. Topanga fossils have been collected at locality 42 .

\section{AREA OF LOWER SEPULVEDA CANYON}

Coarse marine conglomerate, much like that which forms the lower conglomerate member of the Topanga formation along the west side of the Stone Canyon Reservoir, is present east and west of lower Sepulveda Canyon, along the south flank of the mountains. In exposures west of Sepulveda Canyon this conglomerate contains thin beds and partings of light-gray shale which resembles that present in the Miocene elsewhere in the Santa Monica Mountains. The only identifiable fossils found were collected at locality 50 and, according to Doctor Woodring, consist of several specimens of a Tivela; a barnacle and a fragment of a rib bone, both of no value for age determination, were found about 500 feet northwest of this locality.

As shown on the geologic map, this conglomerate locally rests directly upon the Santa Monica slate, but elsewhere its lower exposed part is in fault contact with the Modelo. East of lower Sepulveda Canyon the Topanga conglomerate is unconformably overlain by the basal white platy shale of the Modelo with an angular discordance of $20^{\circ}$ or more.

\section{FOSSILS AND CORRELATION}

Although the sedimentary rocks of the Topanga. formation are probably all of marine origin, many of the finer-grained sandstones and some of the shales are literally filled with plant fragments, and in more than one locality fragile imprints of fragments of leaves and stems of land plants have been observed.
A leaf collected from locality 8, east of Nichols Canyon, and submitted to Dr. R. W. Chaney, of the Carnegie Institution, has been identified as Salix, of the type S. mixta of the middle Miocene of Oregon.

Some of the shale stringers included in the basalt have yielded a few Foraminifera. Samples have been collected at localities 101,102 , and 103 , on and near the Mulholland Highway between the Laurel Canyon road and Cahuenga Avenue. (For description of localities see p. 124.)

The sample collected at locality 102 from a shale stringer in basalt on the Mulholland Highway about 2,000 feet east of the Laurel Canyon road has been examined by D. D. Hughes and Boris Laiming, of Los Angeles. According to Mr. Hughes this sample contains rather poorly preserved calcareous Foraminifera, among which the following 10 species are identifiable:

Bolivina brevior Cushman, rare.

Bolivina cf. B. conica Cushman, very rare.

Bolivina imbricata Cushman, very rare.

Bolivina sp., partly crushed and altered, common.

Nonion costifera Cushman, very common.

Quinqueloculina ef. Q. oblonga (Montagu), common.

Quinqueloculina cf. Q. seminulum (D'Orbigny), very rare.

Valvulineria californica Cushman, rare.

Valvulineria miocenica Cushman, very common.

Virgulina ef. V. californiensis Cushman, rare.

Hughes states that this fauna occurs in the Highland School district, San Luis Obispo County, and is restricted to so-called Monterey or Salinas shale beds 400 to 600 feet above the fossiliferous Temblor sandstone described by Anderson and Martin. ${ }^{34}$ Hughes also states that this fauna also occurs in so-called Monterey shale on the 17-mile drive near the town of Monterey three-quarters of a mile toward Pabble Beach from the tollhouse. In his opinion there is little doubt, therefore, that the sample from locality 102 , collected approximately 500 feet above the base and 6,000 feet below the top of the Topanga formation of the Santa Monica Mountains, is equivalent in age to siliceous shale about 600 feet above the base of the so-called Monterey shale in the Highland School area of San Luis Obispo County and to similar shale in the vicinity of the type section of the Monterey.

The Topanga formation has yielded a fairly good macroscopic fauna of marine invertebrates, which have been collected at numerous widely scattered localities. These fossils have been identified by Dr. W. P. Woodring, of the California Institute of Technology, and are listed below, with his comments. All the fossil localities are accurately shown on Plate 16 and are described on pages $123-124$.

${ }^{34}$ Anderson, F. M., and Martin, Bruce, Neocene record of the Temblor Basin, Calif., and Neocene deposits of the San Juan district, San Luis Obispo County, Calif.: California Acad. Sci. Proc., 4th ser., vol. 4, pp. 37-44, 1914. 
Fossils from the Topanga formation of the eastern part of the Santa Monica Mountains

[Localities plotted on Plate 1. For description of localities, see pp. 123-124]

\begin{tabular}{|c|c|c|c|c|c|c|c|c|c|c|c|c|c|c|c|c|c|c|c|c|c|}
\hline & 2 & 5 & 6 & 7 & 13 & 14 & 20 & 25 & $28 \mathrm{~A}$ & $28 \mathrm{~B}$ & 32 & 33 & 34 & 38 & 42 & 50 & 53 & 56 & 60 & 63 & 66 \\
\hline \multicolumn{22}{|l|}{$\begin{array}{l}\text { Gastropods: } \\
\text { Tegula dalli (Arnold) }\end{array}$} \\
\hline \multirow{2}{*}{\multicolumn{22}{|c|}{$\begin{array}{l}\text { Astraea topangenis (Arnold) } \\
\text { Neverita ef. N. andersoni (Clark) }\end{array}$}} \\
\hline & $x$ & & & & & & $x$ & & $\begin{array}{l}x \\
x\end{array}$ & & & & & & & & & & & $x$ & \\
\hline \multicolumn{22}{|l|}{ Cunatial sp } \\
\hline \multirow{3}{*}{\multicolumn{22}{|c|}{$\begin{array}{l}\text { Crucibulum? sp } \\
\text { Turritella ocoyana Conrad } \\
\text { Turritella temblorensis Wiedey }\end{array}$}} \\
\hline & & & & & & & & & & & & & & & & & & & & & \\
\hline & & & & & & & & & & & & & & & & & & & & & \\
\hline \multicolumn{22}{|l|}{$\begin{array}{l}\text { "Cerithium" sp } \\
\text { Tritonalia edmondi (Arnold) }\end{array}$} \\
\hline \multirow{2}{*}{\multicolumn{22}{|c|}{$\begin{array}{l}\text { Tritonalia topangensis (Arnold) } \\
\text { Galeodes californicus (Anderson and Martin) }\end{array}$}} \\
\hline \multirow{3}{*}{\multicolumn{22}{|c|}{$\begin{array}{l}\text { Oliva californica Anderson } \\
\text { Cancellaria ef. C. dalliana Anderson. }\end{array}$}} \\
\hline & & & & & & & & & & & & & & & & & & & & & \\
\hline \multirow{2}{*}{\multicolumn{22}{|c|}{ "Donus owenianus Anderson }} \\
\hline & & & & & & & & & & & & & & & & & & & & & \\
\hline \multirow{2}{*}{\multicolumn{22}{|c|}{$\begin{array}{l}\text { Bulla sp } \\
\text { nellibranchs: }\end{array}$}} \\
\hline & & & & & & & & & & & & & & & & & & & & & \\
\hline \multicolumn{22}{|l|}{ 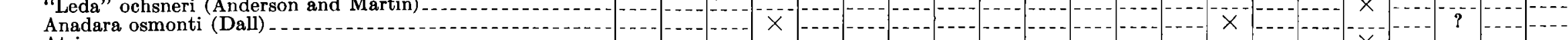 } \\
\hline \multirow{2}{*}{\multicolumn{22}{|c|}{$\begin{array}{l}\text { Atrina sp" } \\
\text { "Pecten", cP.", andersoni (Arnold) }\end{array}$}} \\
\hline & & & & & & & & & & & & & & & & & & & & & \\
\hline $\begin{array}{l}\text { “Pecten” nevadanus Conrad, } \\
\text { Mytilus expansus Arnold }\end{array}$ & & & & & & & $x$ & & $x$ & & & & $x$ & & & & $x$ & $x$ & & $x$ & $\bar{x}^{-}$ \\
\hline Echinochoma? sp & & & & & & & & & & & & & & & & & & & $\bar{x}$ & & $\ldots$ \\
\hline \multirow{2}{*}{\multicolumn{22}{|c|}{$\begin{array}{l}\text { Lucinisca ef. L. nuttallii (Conrad) } \\
\text { Lucinoma acutilineata (Conrad) }\end{array}$}} \\
\hline \multirow{2}{*}{\multicolumn{22}{|c|}{$\begin{array}{l}\text { Lucina richthofeni (Gabb) } \\
\text { Miltha sanctaecrucis (Arnold) }\end{array}$}} \\
\hline & & & & & & & & & & & & & & & & & & & & & \\
\hline \multirow{2}{*}{\multicolumn{22}{|c|}{$\begin{array}{l}\text { Miltha sanctaecrucis (Arnold) } \\
\text { Diplodonta? sp- } \\
\text { Trachycardium schencki (Wiedey) }\end{array}$}} \\
\hline & $\hat{x}$ & & & & & & $x$ & & $x$ & $x$ & & & & & & & $x$ & & & & -1 \\
\hline \multirow{2}{*}{\multicolumn{22}{|c|}{$\begin{array}{l}\text { Trachycardium sp. } \\
\text { Dosinia sp. a }\end{array}$}} \\
\hline & & & & & & & & & & & & & & & & & & & & $x$ & $\begin{array}{ll}--- \\
--1\end{array}$ \\
\hline \multirow{2}{*}{\multicolumn{22}{|c|}{$\begin{array}{l}\text { Dosinia sp. bonradiana (Anderson) } \\
\text { Tivela sp. }\end{array}$}} \\
\hline \multirow{2}{*}{\multicolumn{22}{|c|}{ Pitar? sp }} \\
\hline & & & & & & & & & & & & & & & & & & & & & \\
\hline $\begin{array}{l}\text { Antigona sp } \\
\text { Saxidomus of. S. vaquerosensis Arnold }\end{array}$ & & & & & & & $\hat{x}$ & & & & & & & & & & & & & & $\begin{array}{ll}--- \\
-\cdots\end{array}$ \\
\hline & & & & & & & $x$ & & & & & & & & & & & & & $x$ & $\ldots$ \\
\hline $\begin{array}{l}\text { Chione sp } \\
\text { Paphia? s }\end{array}$ & & & & $x$ & & & & $\cdots$ & & & & & & $\times$ & & & & & $x$ & & --- \\
\hline $\begin{array}{l}\text { Paphia? sp } \\
\text { Tellina? sp...... }\end{array}$ & & & & & & & $x$ & & $x$ & & & & & & $x$ & & & & & & $\cdots$ \\
\hline Macoma? sp.... & $x$ & & & & & & & & & & & $\begin{array}{l}x \\
x\end{array}$ & & $x$ & & & & & & & \\
\hline Sanguinolaria sp. & & & & & & & & & & & & & $X$ & & & & & & & & - n \\
\hline & & & & & & & & 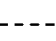 & $x$ & & & & & & & & & & $x$ & & \\
\hline $\begin{array}{l}\text { Spisula cf. S. abs } \\
\text { Panope sp.... }\end{array}$ & & & & & & & $\bar{x}$ & & & & & & & & & & $x$ & & & & \\
\hline hinoid: & & & & & & & & & & & & & & & & & & & & & \\
\hline & & & & & & & & & & & & & & & & & & & & & \\
\hline
\end{tabular}


The following comments are supplied by Woodring:

Most of the fossils in the preceding list represent species already recorded from the Topanga formation at the type locality in Topanga Canyon and in adjoining areas. ${ }^{27}$ Whitney, ${ }^{28}$ on the basis of Gabb's determinations, recorded six species of Miocene fossils, including Turritella ocoyana, from "Hancock's Canyon," an undetermined locality near the east end of the Santa Monica Mountains.

Turritella ocoyana is the most widespread species in the Topanga formation. All large specimens of this species in the collections from the eastern Santa Monica Mountains have a strong keel near the lower edge of the whorl, like those for which Wiedey ${ }^{29}$ used the name $T$. bösei Hertlein and Jordan, which is regarded as a synonym of $T$. ocoyana, for in the type region of $T$. ocoyana in the vicinity of Bakersfield specimens that are similarly keeled and specimens with rounded whorls, which resemble each other in other features, are found at the same locality. T. temblorensis may be another form of $T$. ocoyana.

It is apparent that $T$. ocoyana is a polymorphic species of the group of $T$. terebralis Lamarck, as defined by Guillaume. ${ }^{30}$ It is also apparent that in southern California and Lower California a larger proportion of specimens are strongly keeled than in the Bakersfield region, and that still farther south, in tropical America, where five additional names have been proposed, this phylum of Turritellas was represented during middle Miocene time by veritable giants. ${ }^{31}$

The tropical genus Galeodes, more familiarly known as Melongena, has not heretofore been recorded in southern California, but its presence farther north in San Luis Obispo County ${ }^{32}$ indicated that it would eventually be found there.

The distribution of a small "Cerithium" (localities 7, 13, 28A, 38), Galeodes californicus (localities 7?, 28A), Anadara osmonti (localities 7, 38, 60?), and a small Anomalocardia-like Chione (localities $7,38,60$ ) may indicate a faunal zone within the Topanga formation.

TOPANGA (?) FORMATION ON SOUTH FLANK OF MOUNTAINS

Rocks of somewhat doubtful age on the south flank of the mountains, east of the Temescal fault, rest directly upon the Santa Monica slate. They are different in character from any of the rocks exposed farther west, in the district of Upper Cretaceous and Eocene strata, and have characteristics in common with parts of the Topanga formation exposed on the north flank of the mountains. They also appear to be unconformably overlain by white siliceous shale and sandstone of the lower part of the Modelo formation, a relation which exists for Topanga and Modelo

${ }^{27}$ Arnold, Ralph, New and characteristic species of fossil mollusks from the oil-bearing Tertiary formations of southern California: U S. Nat. Mus. Proc., vol. 32 , pp. 525-526, pls. 40-46, 1907. Eldridge, G. H., and Arnold, Ralph, The Santa Clara Valley, Puente Hills, and Los Angeles oil districts, southern California: U. S. Geol. Survey Bull. 309, pp. 147-148, pls. 27-33, 1907. Kew, W. S. W., Geology and oil resources of a part of Los Angeles and Ventura Counties, Calif: U. S. Geol. Survey Bull. 753, pp. 50-51, 1924. Wiedey, L. W., Notes on the Vaqueros and Temblor formations of the California Miocene, with descriptions of new species: San Diego Soc. Nat. Hist. Trans., vol. 5, No. 10, pp. 95-182, pls. 9-21, 1928. 28 Whitney, J. D., California Geol. Survey, Geology, vol 1, p. 171, 1865.

29 Wiedey, L. W., op. cit., pp. 117-119, pl. 10, fig. 7, pl. 11, figs. 1-3, 5-6.

${ }^{30}$ Guillaume, Louis, Essai sur la classification des Turritelles, ainsi que sur leur évolution et leurs migrations, depuis le début des temps tertiaires: Soc. géol. France Bull., 4th ser., vol. 24, pp. 281-311, pls. 10-11, 33 figs., 1924.

${ }^{31}$ Woodring, W. P., Miocene mollusks from Bowden, Jamaica, pt. 2: Carnegie Inst. Washington Pub. 385 pp. 95-98, 1928.

${ }^{32}$ Anderson, F. M., and Martin, Bruce, Neocene record in the Temblor Basin and Neocene deposits of the San Juan district, San Luis Obispo County, Calit.: California Acad. Sci. Proc., 4th ser., vol. 4, p. 80, pl. 4, fig. 1, 1914 rocks along lower Sepulveda Canyon, only a short distance to the east.

The Topanga (?) formation in this area, east and west of lower Mandeville Canyon, consists largely of soft gray shale and sandstone but contains a few comparatively thin beds of conglomerate which resembles that in the lower conglomeratic member of the Topanga formation along the west side of the Stone Canyon Reservoir. At the base of the formation, resting directly upon the Santa Monica slate on the ridge west of Mandeville Canyon, there is about 50 feet of red conglomerate much like that present in other areas where either the Topanga or the Chico formation has a depositional contact with the old slate.

\section{PROBABLE MIDDLE MHOCENE TRACHYTE}

Ledges and small dikes of light-gray and creamcolored finely crystalline trachyte cut Cretaceous rocks west of the head of Rustic Canyon and Cretaceous and Eocene rocks on the Coast Highway near Castle Rock. These ledges and dikes are only a few inches thick and therefore can not be shown on the geologic map. A prominent ledge of similar trachyte, in part markedly vesicular, cuts sandstone and shale of probable Topanga age in the east wall of Mandeville Canyon three-quarters of a mile above the Beverly Boulevard. The age of this trachyte is a little uncertain, but inasmuch as some of it occurs in rocks of probable Topanga age and pebbles of similar rock are abundant in the basal gray sandstone of the Modelo on the south flank of the mountains west of Rustic Canyon, some of the trachyte is pre-Modelo (earlier than upper Miocene) and probably of about the same age as much of the basalt in the Topanga formation of the Topanga Canyon district.

\section{MODELO FORMATION (UPPER MHOCENE)}

\section{DEFINITION}

The type section of the Modelo formation is rather indefinitely located but lies north of the Santa Clara Valley in the vicinity of Modelo Canyon, 20 miles northwest of the area covered by this report. Continuous outcrops do not connect the type section with the north flank of the Santa Monica Mountains, but the similarity in character and stratigraphic position and the occurrence of lithologic features uncommon to other formations of these areas afford good evidence that the upper Miocene rocks of the Santa Monica Mountains are equivalent, in part at least, to the Modelo formation in the vicinity of the type section. It may be, however, that each of these widely separated sections contains some rocks that have no age equivalent in the other. The Modelo as mapped by Kew in and north of Santa Clara Valley contains rocks older than those which comprise the Modelo in the Santa 
Monica Mountains. ${ }^{35}$ At places in the Santa Clara Valley district, according to Kew, ${ }^{36}$ the Modelo appears to rest conformably upon the Vaqueros formation (lower Miocene), with absence of any intervening strata recognized as representing the Topanga formation (middle Miocene). Kew ${ }^{37}$ is now of the opinion, however, that this Modelo of the type district contains, in its lower part, beds of Topanga (middle Miocene) age.

Because of the striking unconformity in the Santa Monica Mountains between the Topanga and the Modelo, it is a simple task to separate the two formations, and this necessary separation has resulted in a restricted use of the name Modelo. The Modelo of this report is therefore limited to beds most if not all of which are of upper Miocene age, a usage which is in conformity with that intended and approved by the Geological Survey for the Santa Clara Valley district mapped and described by Kew in Bulletin 753. In the area described in the present report the Modelo formation consists of rocks that are all definitely younger than the Topanga formation and its correlative, the "Temblor formation" of San Joaquin Valley.

According to Hudson and Craig, the Modelo formation of the type area consists of a lower bituminous shale series, a lower massive sandstone, a middle siliceous and calcareous shale, an upper sandstone, and an upper cherty shale. Fossils indicative of middle Miocene age were found in the lower Modelo sandstone of the type section. A fauna indicative of uppermost Miocene (Santa Margarita) age was found in a sandstone bed in the upper shale member of the type section. At other localities, north of the type section, rocks that were formerly believed to be of Pico age but were found to carry fossils indicative of uppermost Miocene age rest with marked uncontormity upon the underlying Modelo strata. Hudson and Craig conclude that the type section of the Modelo as mapped by Kew, however, represents continuous deposition from Vaqueros to the end of Miocene time and that the lower shale, the lower sandstone, and the middle shale are of Topanga age and the upper part of the upper shale is of Santa Margarita age. They suggest that the name Modelo be restricted to the unfossiliferous middle part of the Modelo, which includes the upper sandstone and the lower part of the upper shale.

\section{DISTRIBUTION AND GENERAL CHARACTER}

The Modelo formation is exposed on both the north and south flanks of the eastern part of the Santa Monica Mountains but has its widest distribution and greatest thickness on the north flank, west of Universal

\footnotetext{
${ }^{35}$ Hudson, F. S., and Craig, E. K., Ceologic age of the Modelo formation, California: Am. Assoc. Petroleum Geologists Bull., vol. 13, pp. 512-517, 1929.

${ }^{36} \mathrm{Kew}$, W. S. W., Geology and oil resources of a part of Los Angeles and Ventura Counties, Calif.; U. S. Geol. Survey Bull. 753, p. 58, 1924.

3т Oral communication, March, 1928.
}

City. The greatest exposed thickness of the formation is 4,500 feet and is found at the northwestern edge of the area along structure section line $\mathrm{A}-\mathrm{A}^{\prime}$ pls. 16, 17) and in the central part along structure section line $\mathbf{E}-\mathbf{E}^{\prime}$, just west of Stone Canyon. The thickness, however, varies remarkably along the north flank, decreasing to 2,100 feet within a distance of $1 \frac{1}{2}$ miles east of the Stone Canyon locality and to only a few hundred feet near the Encino Reservoir, an area intermediate between and only 3 miles from the two thickest sections.

The Modelo formation overlaps every older sedimentary formation with which it is in contact with striking angular discordance. There are local exceptions - for example, at one locality in the vicinity of Will Rogers's ranch along lower Rustic Canyon, there is little or no angular discordance between the Modelo and the underlying conglomerate of the Chico formation-but on the north flank of the range Chico conglomerate passes underneath the Modelo with a strike actually normal to that common to the Modelo.

The Modelo formation is of marine origin throughout and is composed of two members which, although apparently conformable and grading into each other, are distinct in most of the district and can be separately mapped without much difficulty. A 1-inch bed containing pebbles of siliceous shale and granite embedded in a siliceous shale matrix occurs at the contact between the two members in a lower road cut a few hundred feet south of the Hollywood Country Club, 21/2 miles west of Universal City. There is no discordance in attitude between the beds above and below, and no such thin conglomerate bed or other evidence of unconformity could be found in other near-by exposures. An alternation of cherty siliceous shale and punky diatomaceous shale, beds characteristic of the lower and upper members, respectively, occurs within the 2 or 3 feet of strata directly overlying the 1-inch bed of conglomerate. The writer does not believe that a noteworthy stratigraphic break occurs at this horizon. The maximum thickness of the lower member is 2,750 feet and that of the upper is 2,300 feet. In most of the area covered by this formation the exposed thickness of the lower member is greater than that of the upper and consists of units of thin-bedded shale (pl. 24, $A, B$ ) alternating with more massive units of coarse gray and brown sandstone (pl. 22, $A$ ), the largest of which have been individually mapped on Plate 16. Much of the shale is hard, platy, and opaline and is rich in the calcareous and siliceous remains of microscopic marine animals and plants, such as Foraminifera, Radiolaria, and diatoms. Ordinary soft earthy shale is also very common in this lower member. The upper member, throughout most of its area of exposure, consists largely of soft white punky diatomaceous shale (pl. 25, $C$ ) and is in striking contrast to all por- 


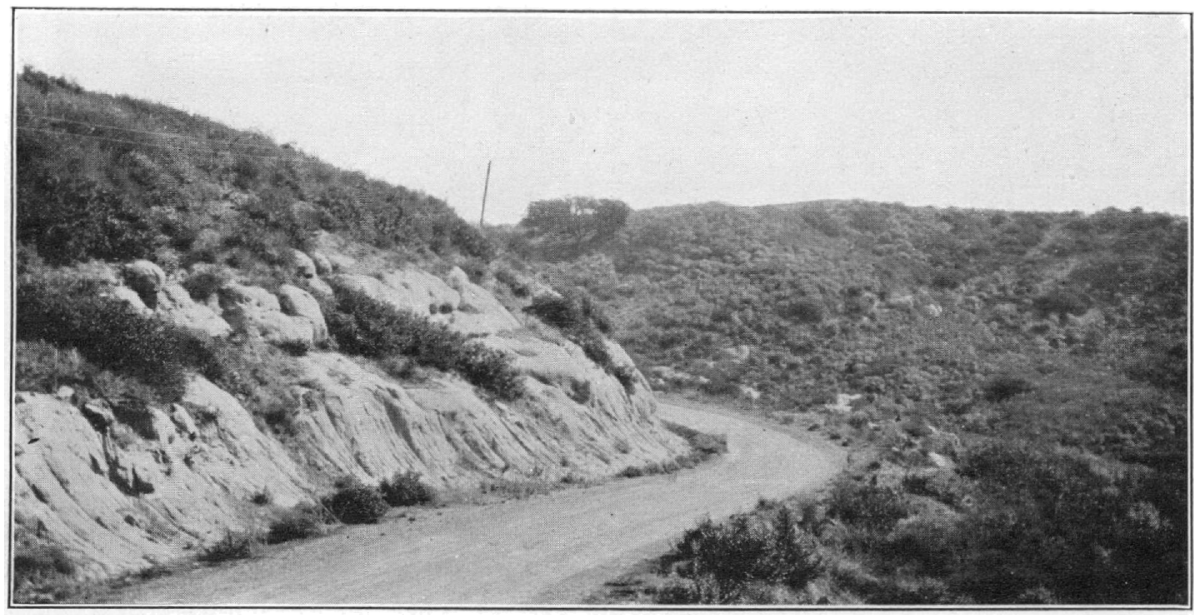

A. ONE OF THE MANY MASSIVE UNITS OF SANDSTONE IN THE LOWER MEMBER OF THE MODELO FORMATION

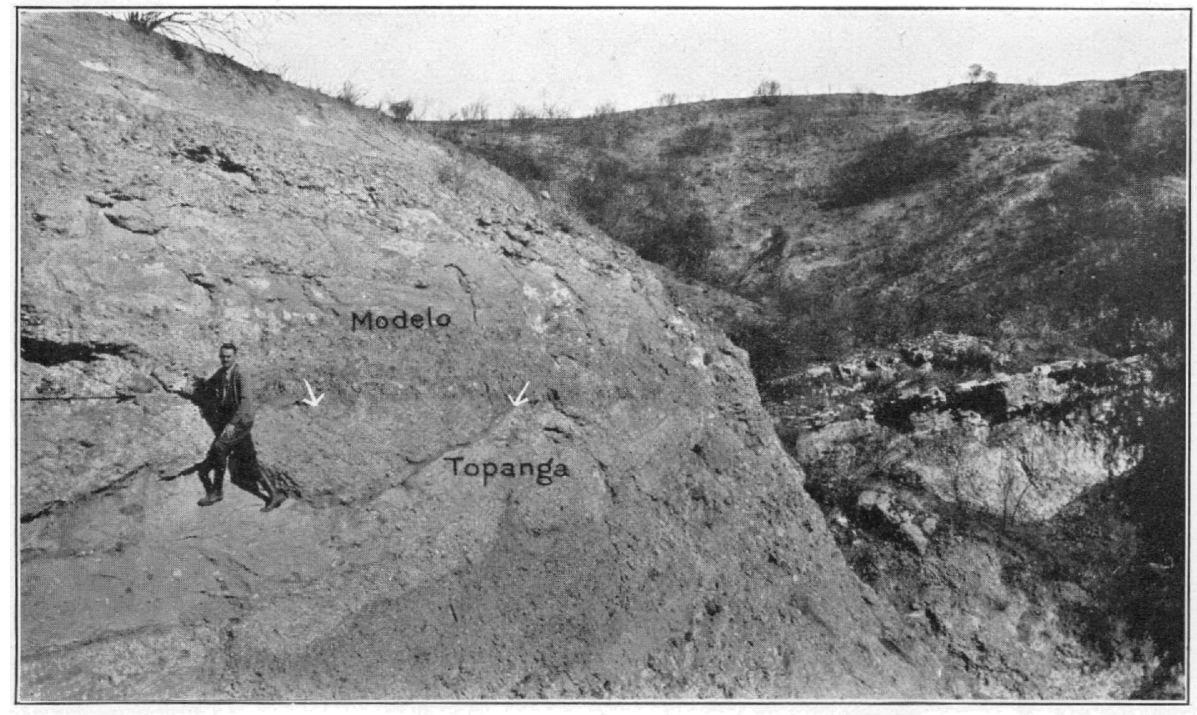

B. UNCONFORMITY BETWEEN BASAL CONGLOMFRATE OF MODELO FORMATION (UPPER MIOCENE) AND CONGLOMERATE OF TOPANGA FORMATION (MIDDLE MIOCENE), NEAR MOHN SPRINGS CAFE IN GARIAPATA CANYON

Shows angular discordance; Modelo dips $10^{\circ} \mathrm{NW}$., and Topanga dips $30^{\circ} \mathrm{S}$

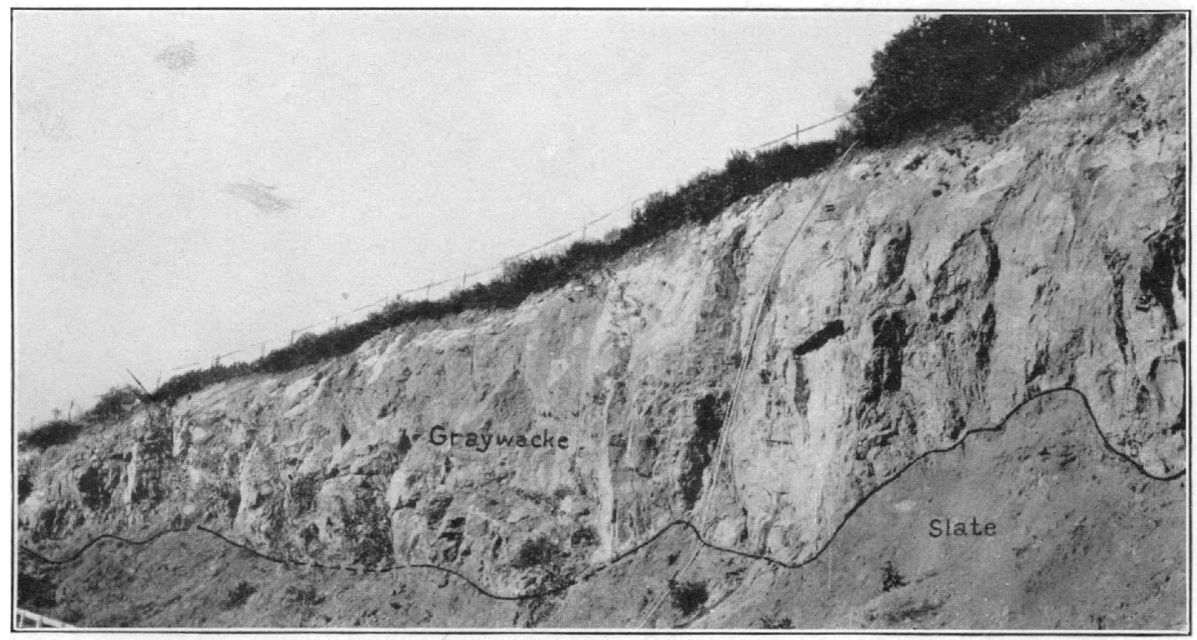

c. BASAL GRAYWACKE OF MODELO FORMATION RESTING ON IRREGULAR EROSION SURFACE OF SANTA MONICA SIAATE (TRIASSIC?) ON SOUTH END OF RIDGE EAST OF BROWN CANYON 


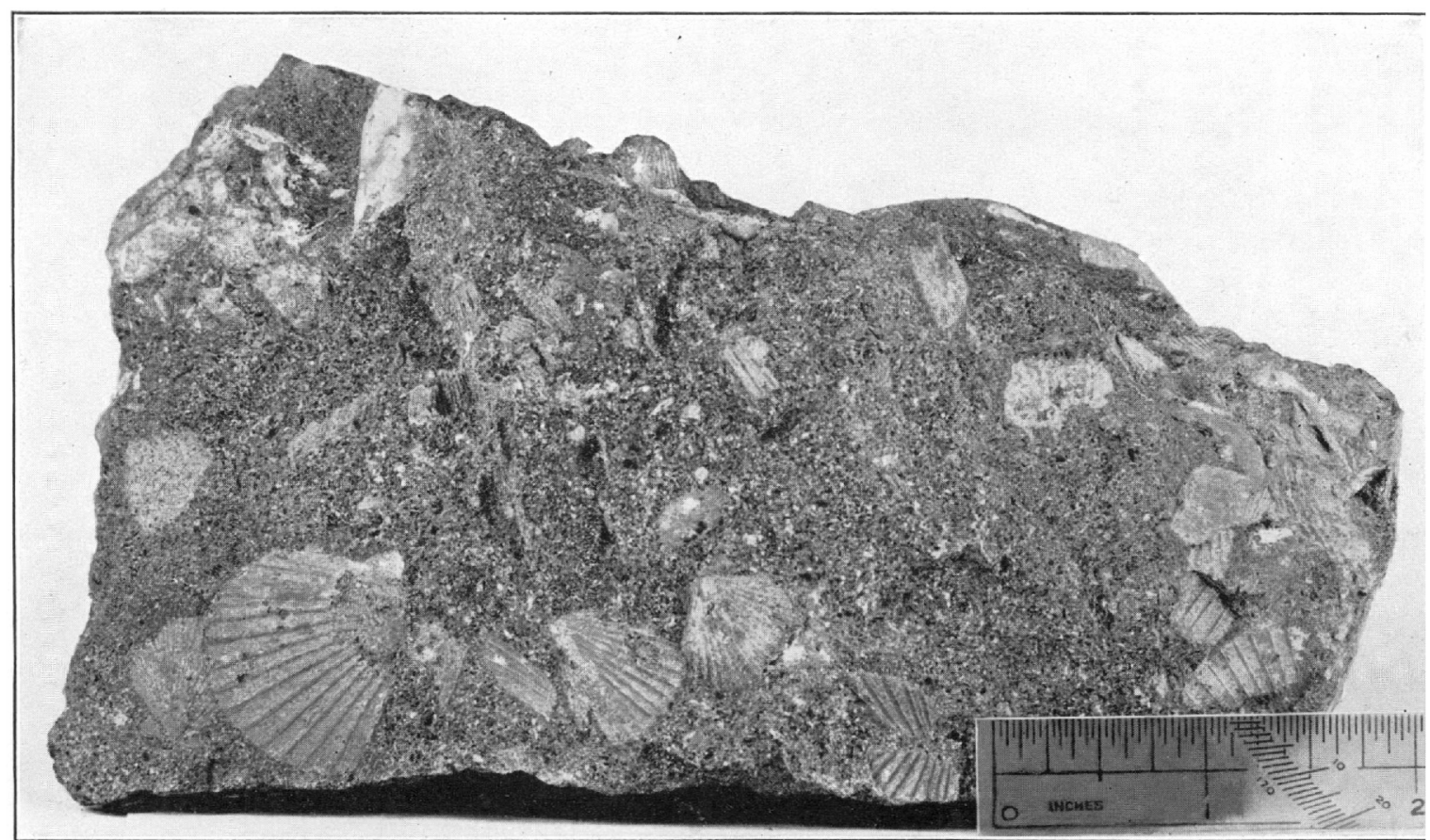

A. IIAND SPECIMEN OF DARK-GRAY BASAL GRAYWACKE OF MODELO FORMATION Shows ahundant fragments of dark slate and easts of "Pecten" raymondi brionianus Trask. Pholograph by K. L. Lohman.

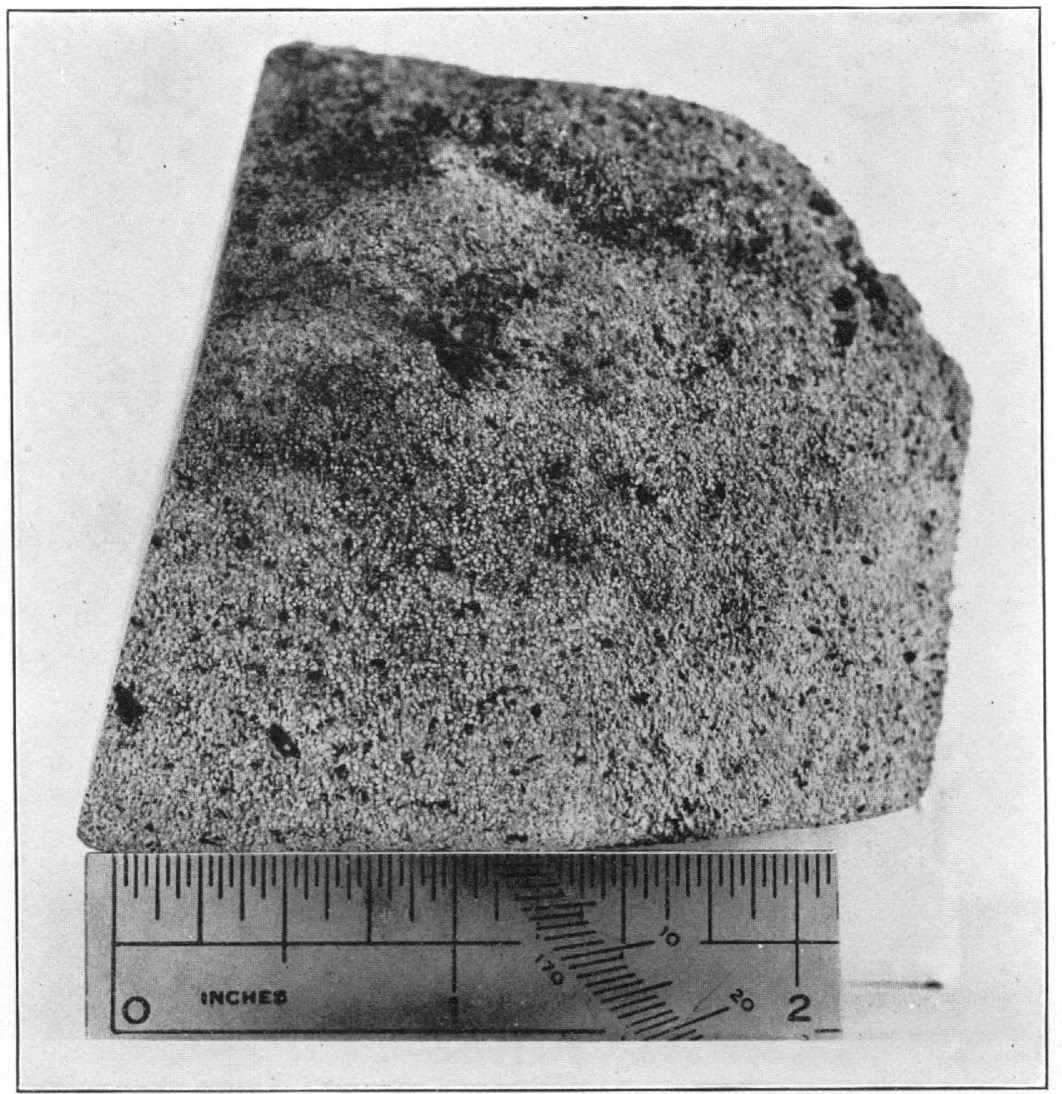

B. HAND SPECIMEN OF BASAL OOLITIC PHOSPHATE OF MODELO FORMATION Weathered surface shows protruding onlite grains and fragments of black slate. Photograph by
K. E. Lohman. 


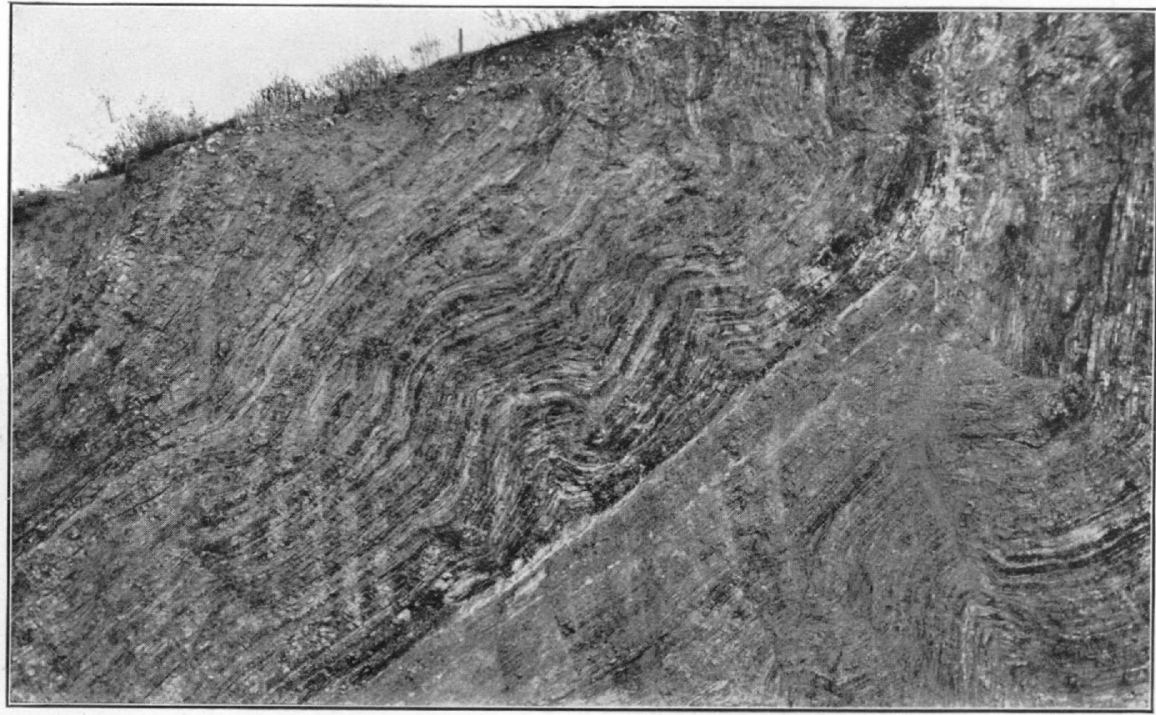

A. GRAY CHERTY SHALE IN LOWEST SHALE UNIT OF LOWER MEMBER OF MODELO FORMATION ALONG MULHOLLAND HIGHWAY

Shows folding of incompetent beds above a planc of slippage.

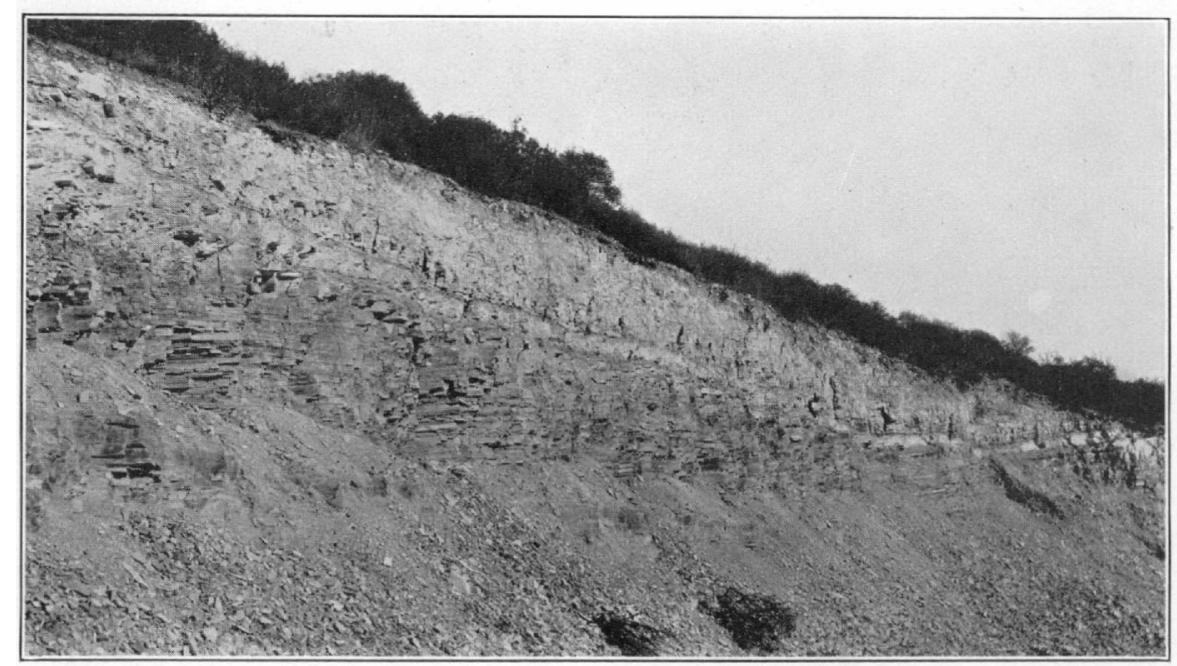

B. NONCHERTY SILICEOUS PLATY SHALE IN UPPER SHALE UNIT OF LOWER MEMBER OF MODELO FORMATION ALONG MULHOLLAND HIGHWAY

A bed of light-gray voleanic ash does not quile parallel the bedding of the underlying shale.

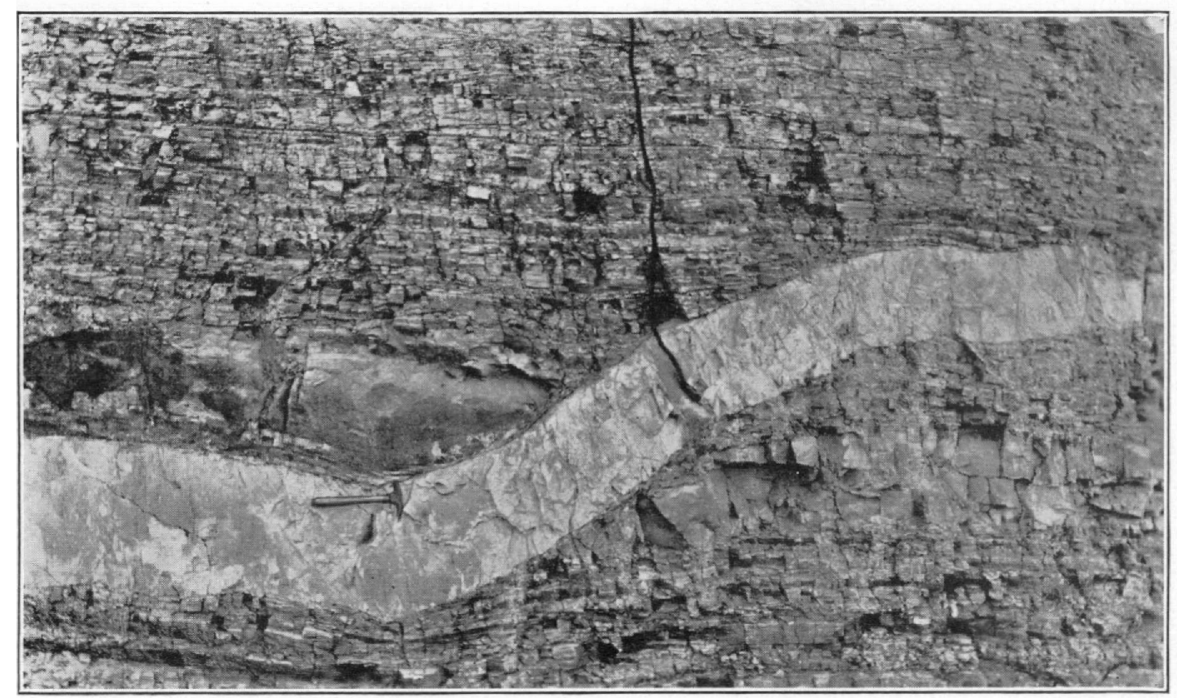

C. SANDSTONE DIKE IN GENTLY TILTED MODELO SHALE ALONG MULHOLLAND HIGHWAY Dike passes into a sill at left and lenses out entirely. See also Plate 25, $A$. 


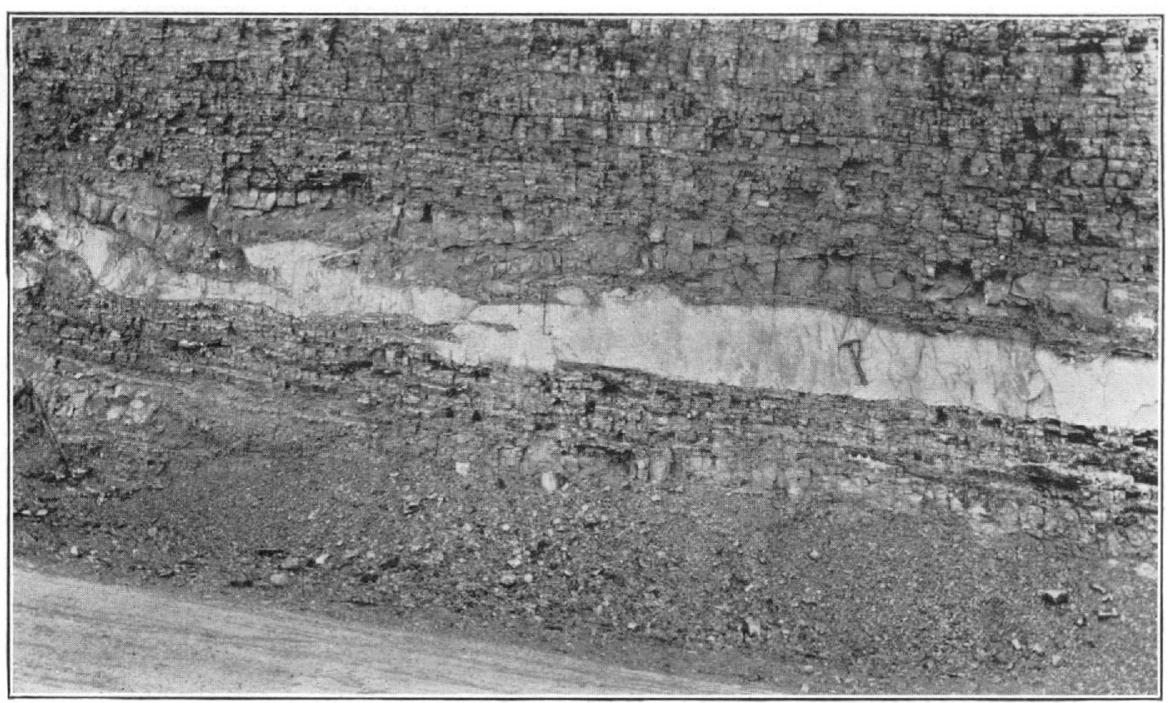

A. SILL-LIKE INTRUSION OF SANDSTONE IN MODLLO SHALE

The sandstone Ienses oul at le[t; at right it passes into the dike shown in Plate 21,6 :

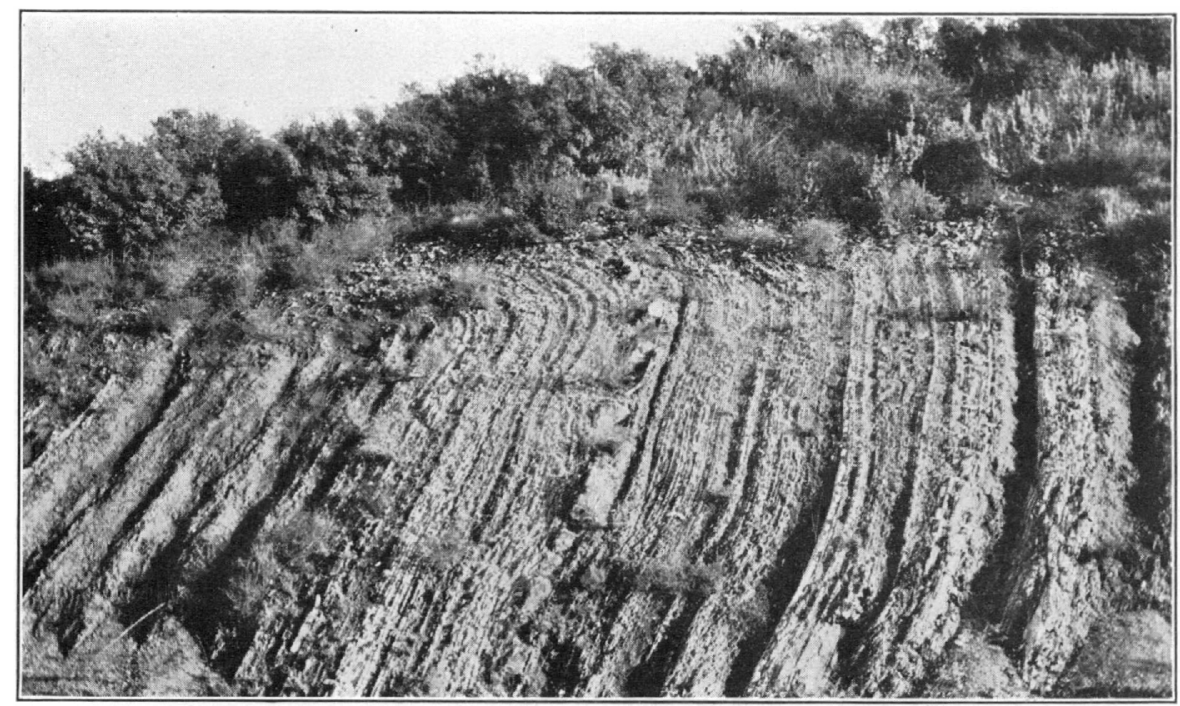

B. HAID WHITE SILICEOUS SHAJ,E IN UPPER PART OF LOWEH MEMBER OF MODEI, FORMATION 1 MILE SOUTI OF GIRARD, CALIF.

Intercalated with soft clay shale, a hed of limestone, and a fow thin beds of sindstone.

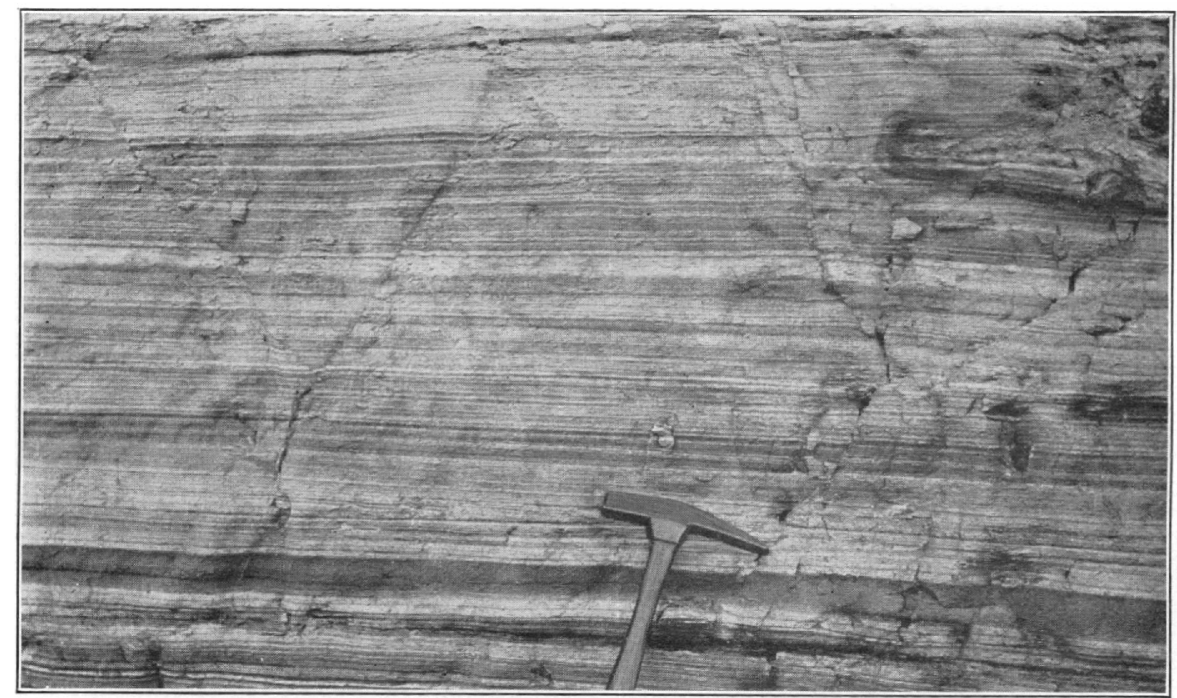

C. FINELY LAMINATED WHITE AND LIGHT'-(IRAY PUNKY DIATOMACEOUS SHALE From beds just south of Ventura Bonlevard and east of Girard. 


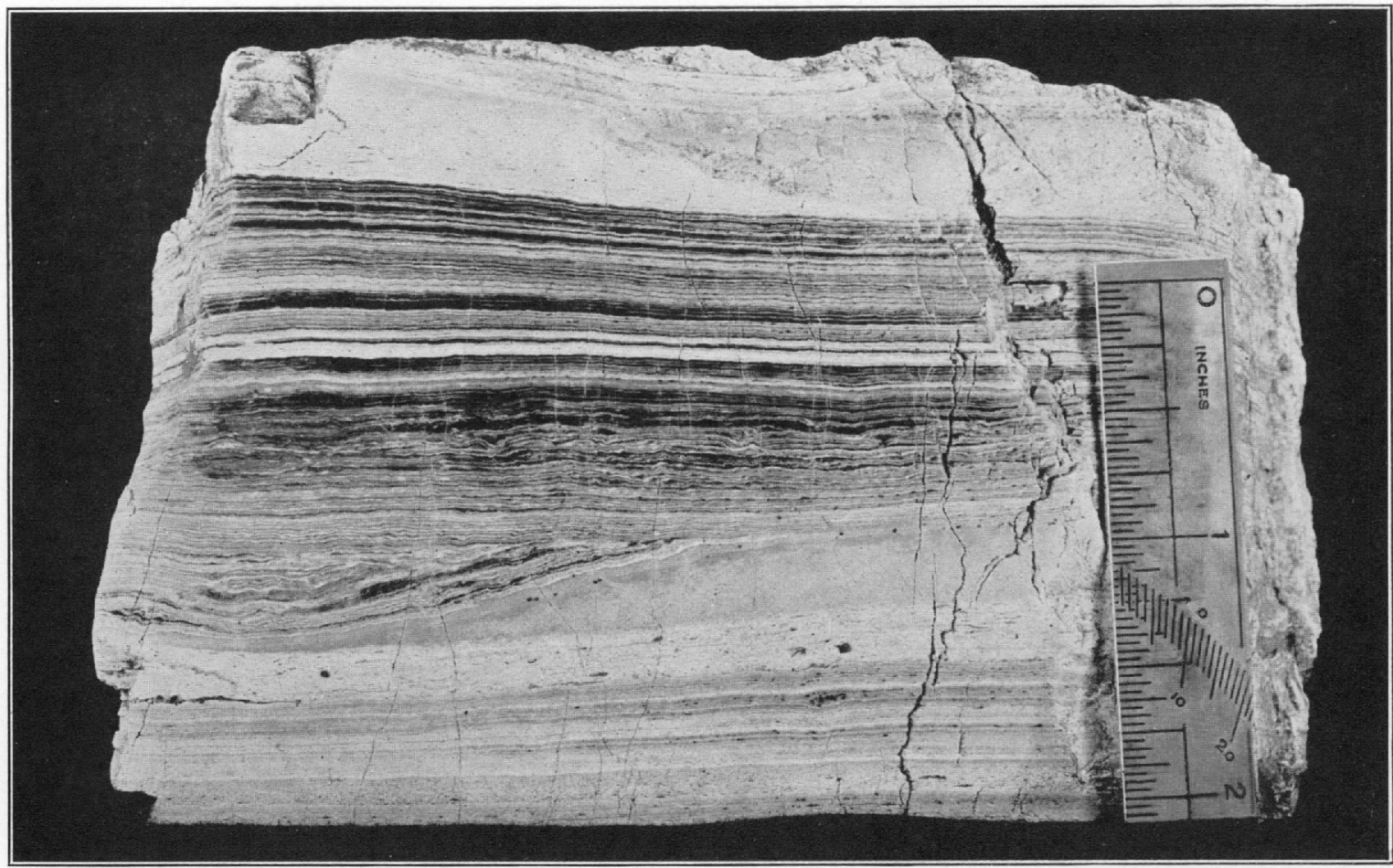

A. FINELY BANDED CHERTY SHALE FROM LOWER PART OF MODELO FORMATION

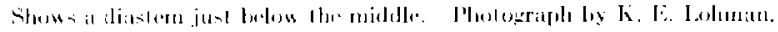

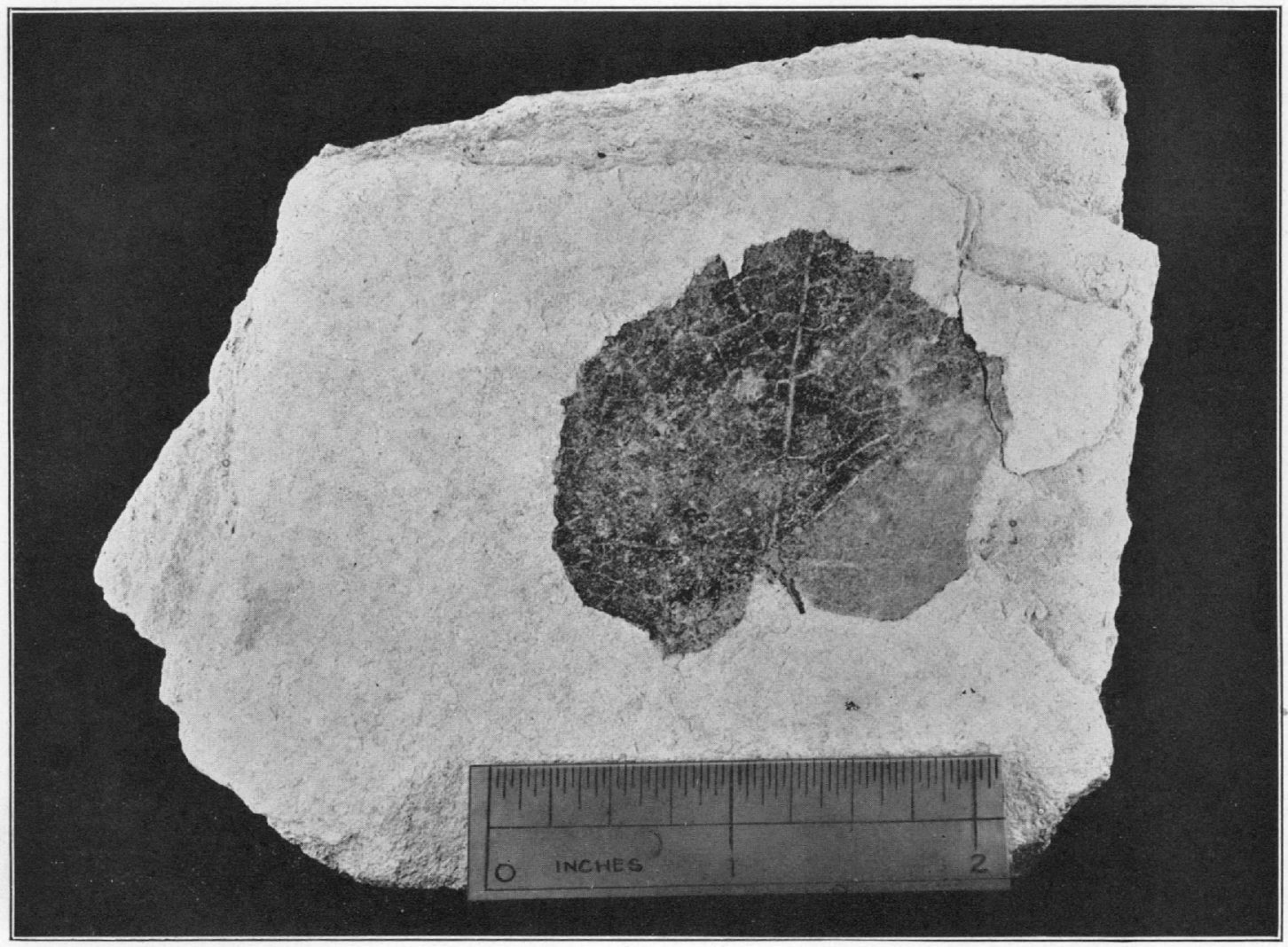

B. WELL-PRESERVED IMPRINT OF LEAF FROM LAND PLANT (PLATANUS DISSECTA) IN PLATY SHALE OF LOWER

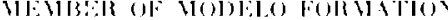



tions of the lower member as well as all other stratigraphic units in the eastern part of the Santa Monica Mountains.

Only the lower part of the lower member of the Modelo is exposed along the south flank of the mountains, the remainder of the formation being concealed beneath an extensive Pleistocene alluvial plain which is crossed by numerous channels of Recent alluvium.

A section of the entire Modelo formation measured in the western edge of the area near structure section line $\mathrm{A}-\mathrm{A}^{\prime}$ (pl. 16) and exposed in greater part along the Garrapata Canyon and Girard road is presented below. As the geologic map clearly shows, the lower member of the Modelo in this section includes some sandstone but contains none of the thick beds of soft sandstone present only 2 or 3 miles farther east and, for a similar reason, is radically different from the lower Modelo still farther east, in the vicinity of Stone and Brown Canyons, along structure section lines $\mathrm{E}-\mathrm{E}^{\prime}$ and $F-F^{\prime}$. Another striking difference between the lower Modelo along the Garrapata Canyon and Girard road and that of the north flank near Stone and Brown Canyons is in the character of the shale. Instead of the relatively soft shale described below, the shale near Stone and Brown Canyons is largely of the hard white platy type throughout all shale units in the lower member of the Modelo. This platy shale becomes less conspicuous as the lower member is traced farther east and appears to be partly replaced by soft bluish-gray and brown earthy shale.

Section of the Modelo formation exposed along the Garrapata Canyon and Girard highway north of Mohn Springs

\section{Modelo formation:}

19. Stratigraphically higher beds of the diatomaceous shale unit of No. 18 form the lowlying hills north of Ventura Boulevard near Girard and are associated with progressively more and finer grained soft sandstone as the top of the unit is approached. Probable approximate thickness . . . . . . 1,100

18. White shale, thin bedded and becoming progressively more fissile, punky, and diatomaceous upward from base toward middle of unit. Beds of soft fine-grained brown and gray sandstone are intercalated with highly diatomaceous shale throughout lower exposed portion, where lenses and concretionary beds of hard light-gray limestone from 1 foot to 3 feet thick are common. Thickness exposed south of Ventura Boulevard on ridge just east of Girard.

17. Compact and thin-bedded brown and lightgray shale with a few light-gray limestone concretions and concretionary beds. Free from sandstone except for a few thin beds of fine texture in upper $\mathbf{5 0}$ feet. Bedding planes of shale contain innumerable white granular specks and scattered black specks of carbonaceous material. Diatoms are present, but shale is not a typical diatomite.
Modelo formation-Continued.

16. Soft light-gray sandstone with numerous thin partings of bluish-gray shale in lower part. Sandstone ranges from fine and thin bedded in lower part to very coarse and gritty in upper part, where rounded boulders of sof $t$ bluish-gray shale from 8 to 10 inches in diameter are common. Bedding in upper, more massive part is very irregular, and there is distinct evidence of scouring and truncation of beds

15. Soft light-brown and grayish-brown shale with a 1-foot bed of yellow limestone at the base and light-gray slabby calcareous beds a few feet above. Shale is thin bedded and intercalated with a few $1 / 4$-inch beds of fine brown sandstone. Small but distinct rounded and oblong white specks are abundant along most bedding planes......

14. Soft light-brown sandstone of medium-coarse texture. Some beds contain much biotite. Very little shale is present, but several thin beds of ycllow-weathering limestone occur

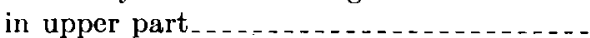

13. Light bluish-gray thin-bedded shale and sandy shale intercalated with beds of soft fine gray and brown sandstone from one-fourth of an inch to 6 inches thick. Most of the shale is soft, but a 1-foot zone of platy opal shale occurs near the base, directly above a 1-foot bed of yellow limestone. Foraminifera collected from lower part.......

12. Soft gritty gray and brown arkosic sandstone in distinct beds from 2 inches to 6 feet thick separated by partings and thin beds of bluish-gray and white shale. A few irregular beds of yellow-weathering limestone occur in upper part. ............

11. Hard white platy opaline shale and soft shale, poorly exposed, in lower 50 feet, apparently grading upward into beds composed largely of firm brown shale and sandy shale with thin beds of fine gray sandstone.

10. Soft brown arkosic sandstone in beds from 4 inches to 3 feet thick separated by thin shale partings. Sandstone is coarse, gritty, and poorly sorted, with mineral grains as much as one-eighth of an inch across......

9. A striking and distinctly thin-bedded series of brown and light-gray shale and fine sandstone. Fine brown sandstone comprises most of lower 100 feet or more and occurs in distinct beds from 1 inch to 12 inches thick, which are separated by thin partings or beds from one-eighth of an inch to 2 inches thick of soft bluish-gray shale and hard white platy shale. The whiteweathering shale is brown when fresh and contains abundant calcareous Foraminifera. Beds of sandstone become progressively less prominent above, and north of the road crest this unit is composed largely of beautifully laminated foraminiferal shale, which ranges from dark brown to light brown and gray and from soft to hard platy opal shale. The most abundant type is brown and compact but not opaline. Thin partings of fine brown sandstone 
Modelo formation-Continued. occur throughout, and beds and lentils of yellow-weathering limestone from 1 foot to 3 feet thick are common. Two beds of yellowish-white bentonite, 4 to 6 inches thick, occur about 300 feet above the base.-

8. Thin-bedded bluish-gray and brown shale and sandy shale with several prominent beds of yellow-weathering limestone and limestone concretions. Becomes more sandy upward, with thin beds of fine brown sandstone in upper part. Top of this unit is 100 yards south of crest of road....................

7. Soft brown and dark-gray sandy shale, fine sandstone, and shale in a thin-bedded series. Beds range from less than 1 inch to 1 foot in thickness, and beds of soft brown sandstone are thicker in lower part. Beds and lenses of hard brown limestone are common.........................

6. Hard white opal shale intercalated with soft brown shale, all in thin distinct beds which average less than 1 inch in thickness. Individual beds of hard white shale are as a rule beautifully banded with dark and lightgray laminae, with which are a few $1 / 8$-inch laminae of fine well-sorted sandstone. Some of the hard platy shale is highly opaline and breaks with conchoidal fracture. A few 6-inch beds of hard brown limestone occur in this unit. Some soft brown shale contains calcareous foraminifers. Thickness approximate, owing to presence of poorly exposed anticline.

5. Brown and bluish-gray soft shale and sandy shale with scattered concretions and lenticular beds of hard yellowish-brown limestone as much as $1 \frac{1}{2}$ feet thick. Columnar jointing conspicuous in lower part. White bed of bentonite, 6 inches thick, occurs 15 feet above base. Part of this unit is poorly. exposed ...............................

4. Massive brown fine-grained sandstone; grades upward into overlying shale and sandy shale..................................

3. Coarse argillaceous brown and gray sandstone, thinly but irregularly bedded and containing calcareous nodules with a few calcareous foraminifers. ................-

2. Brown arkosic and gritty sandstone of medium-coarse texture which grades downward into conglomerate and upward into earthy sandstone........................

1. Basal conglomerate and sandstone in distinct well-indurated beds 6 to 18 inches thick. Polished subangular and well-rounded pebbles, cobbles, and boulders 1 foot or less in diameter are very abundant; about 75 per cent of them are gray and purplish quartzite; the remaining 25 per cent consist of dark and light colored porphyries, together with light-gray granite and gneissic granite in subordinate amount. Other rock types, such as boulders of sandstone and slate, are notably scarce or absent. All this material is embedded in a coarse matrix of angular quartz and feldspar grains..............

Unconformity with angular discordance in dip of about $40^{\circ}$. Topanga formation.
LOWER MEMBER

General features.-The lower member of the Modelo formation, which consists of alternating units of shale and massive sandstone and crops out over much of the north flank of the range west of Universal City and along the south flank west of Beverly Hills, is much more widespread than the upper member, which is restricted to a relatively narrow band on the north flank. (See pl. 16.) In much of the area where the Modelo rests directly upon the Santa Monica slate there is a hard massive bed of conglomeratic graywacke at the base of the formation, which is literally filled with small angular fragments of slate. (See pls. 22, $C$, and $23, A$.) This bed is the most highly fossiliferous in the entire formation for macroscopic forms and is commonly 20 to 30 feet thick, though ranging from 50 feet down to the vanishing point. It is well exposed around the head of Sepulveda Canyon, south of the Mulholland Highway, and on the south flank between Stone and Benedict Canyons. Where this bed is not present its position at the base of the Modelo is occupied by shale and oolitic phosphate or, in areas some distance from the Santa Monica slate, as in Garrapata Canyon, by a coarse conglomerate without slate fragments and much like that common in the underlying Topanga formation.

There are two strikingly lenticular sandstone units somewhat higher in the Modelo formation; both are on the north flank of the range, one in the lower part of the formation between Sepulveda and Stone Canyons and the other slightly higher and farther west, in the area west of the Encino Reservoir. The former appears to be the easier to explain. Although this unit has a maximum thickness of 1,100 to 1,200 feet along structure section line $\mathbf{E}-\mathrm{E}^{\prime}$, it lenses out entirely to the east and to the west within distances of 1 mile to $1 \frac{1 / 4}{4}$ miles. (See pl. 16.) Its upper surface is parallel to the bedding in overlying units of the Modelo, but its base conforms in a remarkably close manner to the basinlike form of the old pre-Modelo topography of the underlying slate. As all of the Modelo formation is marine this lens of sandstone accumulated on the sea bottom and almost succeeded in filling a pronounced trough which crossed the present site of the Santa Monica Mountains and was a part of the old pre-Modelo surface. This sandstone is overlain, with intervening shales, by other sandstones which also lens out to the east. (See pl. 16.) The discontinuity of at least some of these sandstone units, as shown on the geologic map, is apparently due largely to the fact that most of them appear to die out and have comparatively few or no stratigraphic equivalents at points farther east along the strike; but there are other occurrences, such as the prominent sandstone lens west of the Encino Reservoir, in which the discontinuity shown is due not to the actual disappearance of a stratigraphic unit but largely to its lateral change into strata composed predominantly 
of shale and a relatively small amount of sandstone. It is a change in facies - not a radical change in thickness of beds at any one horizon-which accounts for the lenticularity of many of the sandstone units.

The character of the shale in the lower member of the Modelo formation also undergoes distinct lateral changes, a fact which is particularly evident when the type of shale composing most of the section in the eastern part of the area, particularly east of upper Benedict Canyon, is compared with that in the western part, along the Garrapata Canyon and Girard road. In the more eastern district the shale of all parts of the lower member, exposed in road cuts along the Mulholland Highway and subsidiary roads leading to the north and to the south, is in greater part of the hard, platy, opaline type (see pl. $24, A, B$ ), and much of it is relatively free from intercalated partings and thin beds of sandstone. In the western edge of the area covered by this report hard, platy opaline shale in notable amount occurs only as a 100 -foot unit in the lower part and a second 100-foot unit-in the upper part of the lower member, most of the remainder consisting of thin-bedded soft but firm brown shale and fine sandstone.

On the south flank of the range, west and northwest of Beverly Hills, between Mandeville and Coldwater Canyons, the exposed part of the lower Modelo is similar in stratigraphic sequence to the lower Modelo directly to the north, on the north flank. The basal graywacke is very well developed on the south flank between Stone and Benedict Canyons and is overlain by 50 to 100 feet of hard platy shale, which in turn is overlain by a thick and widespread unit of soft gray and brown gritty sandstone much like that which forms the huge sandstone lens on the north flank just west of Stone Canyon.

Along the coast northwest of Santa Monica the exposed Modelo consists of a highly deformed mass of thin-bedded soft brown and hard, platy shale, some of which is highly bituminous, stained dark gray or black, and impregnated with considerable sulphur.

Basal graywacke.-The graywacke at the base of the Modelo in much of the area where this formation directly overlies the Santa Monica slate is remarkable in being so distinct, so rich in marine invertebrate fossils, and composed to so large an extent of rock fragments derived from the underlying slate. Much concerning its origin is thus readily determinable, and its good exposures in easily accessible localities make it a choice illustration of geologic processes active here prior to and at the beginning of Modelo time.

This basal graywacke is massive, is resistant to weathering, and commonly crops out in a vertical wall 20 to 30 feet high. Outcrops of this nature occur on ridges near the head of Sepulveda Canyon, just west of the Encino Reservoir, and, in somewhat subdued form, on ridge tops along the south flank of the range between Stone and Benedict Canyons. Its dark-gray color serves to identify the rock at a glance; by closer inspection this color is found to result from the abundance of angular to well-rounded fragments of black slate, which commonly average less than 1 millimeter in diameter. Subangular grains of colorless quartz are recognizable with a hand lens and have been found to be very abundant in thin sections and to be associated with grains of plagioclase and orthoclase feldspar, microcline, and quartzite. Resting upon the Santa Monica slate in some areas is a rock of light-gray speckled appearance, which is an impure microcrystalline limestone containing many fragments of black slate. At other places the graywacke contains scattered oolite grains or gives place entirely to a 6-inch bed of oolitic phosphate that is directly overlain by platy siliceous shale.

On the ridge west of the Encino Reservoir abundant slate fragments in the basal bed of the Modelo are associated with a greater abundance of cobbles of light-gray granite. This locality therefore does not offer a typical example of the basal graywacke.

The best exposure of typical graywacke and its contact with the underlying slate is to be found 2 miles northwest of Beverly Hills, in the road cut that leads up the south end of the ridge just west of Benedict Canyon. (See pl. 22, C.) Parts of the graywacke are very fossiliferous at this locality and on the ridge west of Brown Canyon and have yielded several species of fossil marine invertebrates, which are listed on page 110. Plate 23, $A$, shows a hand specimen of this graywacke with many casts of "Pecten" cf. $P$. raymondi brionianus Trask, a fossil that almost everywhere greatly outnumbers all other species combined. In the exposure shown in Plate 22, $C$, the contact between the slate and the graywacke is very uneven; irregular pockets occur on the old surface of the slate and are filled with well-rounded cobbles and boulders of schist, porphyry, basalt, and soft sandstone as much as 12 inches in diameter. Narrow cracks filled with lower Modelo sediment extend for several feet below the contact.

Oolitic phosphate-Oolitic phosphate, consisting to a large extent of the amorphous mineral collophane, occurs as a 6-inch bed at the base of the Modelo on the first ridge top west of the Stone Canyon Reservoir and at other scattered localities as far west as Mandeville Canyon. In the west wall of Stone Canyon a 1 to 2 foot zone of oolitic phosphate occurs at the base of the bituminous shale described on page 109. Although few descriptions of oolitic rocks in the California Tertiary can be found in the literature, the presence of rock of this type is apparently not uncommon in some parts of the Miocene. Dr. R. D. Reed, ${ }^{38}$ who has briefly described the character and occurrence of oolitic phosphate in the "Monterey shale" (Salinas

Reed, R. D., Phosphate beds in the Monterey shales: Geol. Soc. America Bull, vol. 38, pp. 195-196, 1927. 
shale) of the Salinas Valley region, has kindly loaned to the writer a suite of thin sections made from the Salinas Valley material. The principal difference between this material and the Modelo phosphate of the Santa Monica Mountains is its mode of occurrence and the character of the matrix surrounding the oolite grains.

The oolitic phosphate at the base of the Modelo is light brown to grayish brown and, unless examined in hand specimens, might readily be mistaken for sandstone. As is shown in Plate 23, $B$, weathered surfaces are, however, covered with rounded pellets about 0.5 millimeter in diameter which, because of their rather uniform size and roundness, are strikingly different from the ill-sorted angular mineral grains common to most Tertiary sandstones of California. These pellets are associated with small angular fragments of black slate, and, from the fact that they protrude and give a rough surface to the rock, they appear upon casual observation to be embedded in a relatively soft matrix.

Thin sections of this rock reveal a very uniform texture and mineral composition. The oolite grains range from 0.2 to 0.7 millimeters in diameter, are in contact throughout almost the entire rock, and are formed around nuclei of black slate, quartz, and quartzite fragments. The small interstitial areas remaining between the adjacent oolite grains are filled with calcite and a deep-brown substance which appears to be slightly anisotropic. The accompanying chemical analysis of the oolitic phosphate suggests that this brown substance is iron oxide $\left(\mathrm{Fe}_{2} \mathrm{O}_{3}\right)$. It fills a few somewhat larger areas in the slides, and these areas contain small spots of collophane about 0.05 millimeter in diameter which have no apparent nuclei. Calcite also fills veins which individually cut across as many as 15 oolite grains and in several sections has actually replaced some of the collophane composing these grains.

Most of the oolite grains have a pale-brown color and are clouded with irregular areas and disseminated minute specks of hematite, which in reflected light have a deep reddish-brown color. Practically all the oolite grains have concentric structure, although this structure, in different grains results from different causes and varies considerably in distinctness. The most common and most distinct concentricity is made apparent by one or more rings of brown iron oxide. In other places disseminated minute brown specks of iron oxide are arranged in discontinuous concentric bands. In a large proportion of the grains concentric structure is apparent only because of distinct differences in the index of refraction of adjoining growth bands of collophane. The collophane of several fragments examined in refractive-index liquids proved, however, to be consistent in having an index of refraction between 1.61 and 1.62 , a uniformity of this property which, as noted in the thin sections, is true for many individual grains. As shown by Rogers, ${ }^{39}$ the refractive index of collophane ranges from 1.573 to 1.623 .

Chemical analyses of oolitic phosphate from the base of the Modelo formation, on ridge west of Stone Canyon, and of Wyoming phosphate

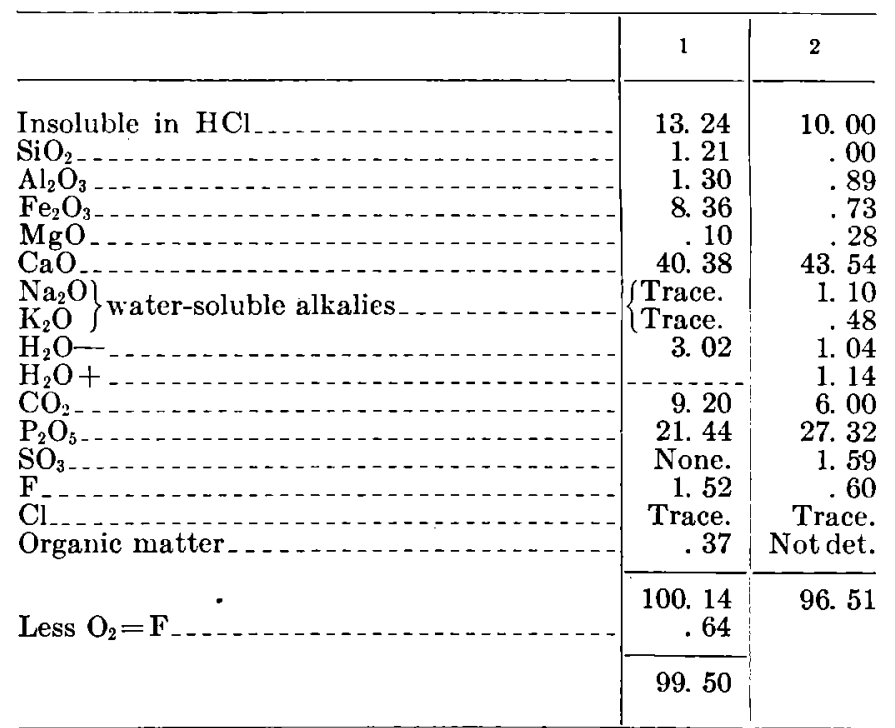

1. Phosphate from Modelo formation. J. G. Fairchild, analy st.

2. Phosphate from main phosphate red $2 \frac{1}{2}$ miles east of Cokeville, wyo. (Twen2. Phosphate from main phosphate red $21 / 2$ miles east
hofel, W. H., Treatise on sedimentation, p. 395, 1926).

The percentage of anhydrous phosphate $\left(\mathrm{Ca}_{3} \mathrm{P}_{2} \mathrm{O}_{8}\right)$ computed from the analysis of the sample from the Modelo formation is 46.8. On the assumption that all of the water and fluorine present is combined with this tricalcium phosphate to form collophane, the total amount of collophane is approximately 51.3 per cent. In the sample analyzed the 8.36 per cent of $\mathrm{Fe}_{2} \mathrm{O}_{3}$ (hematite) is somewhat less and the calculated 19.7 per cent of $\mathrm{CaCO}_{3}$ (calcite) is greater than the amounts. of these minerals suspected from examination of thin sections. The $\mathrm{Al}_{2} \mathrm{O}_{3}$ and $\mathrm{SiO}_{2}$ are present in the rock as constituents of the detrital material that forms nuclei for the oolite grains.

Sandstone.-The distribution and lenticular nature of major sandstone units in the Modelo formation are described on page 104. These sandstones, although commonly very massive (see pl. $22, A$ ), are soft and are even less resistant to erosion than the associated hard platy shale, a condition which is made apparent by the fact that many low hills, although composed mostly of sandstone and surrounded by low areas of sandstone outcrop, are capped by platy shale. Many of the major sandstone units, particularly those in the lower and middle parts of this member east of the Encino Reservoir, contain abundant sandstone concretions. Conglomerate is scarce, and, except for the basal unit already described and some fine conglomerate in a part of the prominent sandstone lens west of the Encino Reservoir, rock of this type is practically

32 Rogers, A. F., Mineralogy and petrography of fossil bones: Geol. Soc. A merica I.ul., vol. 35, pp. 541-547, 1924. 
absent from the entire Modelo formation, although some of the major sandstone units are very coarse and gritty.

The areas mapped as shale, particularly west of the Encino Reservoir, contain a large amount of sandstone intercalated as thin beds between equally thin layers of shale. The average thickness of these beds is probably 2 or 3 inches, and the sandstone composing them is in general about as fine and as well sorted as any of the other sandstones of the district. Curve 6 in the accompanying chart (fig. 8) illustrates the texture and fairly woll sorted character of these thinbedded sandstones and may be compared with curve 3 , which represents an unusually illsorted sandstone from this same thinbedded series of Modelo shale and sandstone, and curve 4 , which represents a much coarser but even better sorted Pleistocene marine sand.

Although some of the sandstones of this marine formation are rather poorly sorted as to size of mineral grains, all of them appear to be very clean and free from disseminated clayey material. Except in the rare conglomeratic portions, where the larger detrital rock fragments are fairly well rounded, the mineral grains of all sandstone samples examined are very angular and commonly have jagged points and show little evidence of abrasion.

Mineralogically, all these so-called sandstones of the Modelo and also those of the underlying Topanga formation are arkoses, for they contain from 30 to 60 per cent of feldspar. Most of the feldspar grains are turbid, although some are as clear as any of the quartz. Orthoclase appears to be much the most abundant feldspar, but, to judge from the indices of refraction and the occurrence of polysynthetic twinning, anorthoclase and oligoclase are very common, and all other species of plagioclase are present. The quartz and feldspars are associated with heavy minerals, which commonly form about 1 per cent or less of the entire rock. The heavy minerals identified in samples examined are, in the approximate order of abundance, leucoxene, black opaque minerals (probably ilmenite and magnetite), garnet, zircon, tourmaline, titanite, rutile, and green hormblende. No striking difference was found in the mineralogy of sandstones of the Modelo, Topanga, Sespe (?), Vaqueros (?), and Chico formations; careful study of a large number of samples from each of these formations would probably reveal some distinctive mineralogic characteristics; but inasmuch as all these formations have probably been derived directly or indirectly from the same source, it is believed that such characteristics would consist of differences in percentage composition rather than of important differences in the minerals present.

Sandstone dikes.-In several exposures along the Mulholland Highway, within 2 or 3 miles east of the Girard and Garrapata Canyon road gently dipping shale in the lower member of the Modelo formation is cut by intrusive bodies of soft light-gray sandstone. Most of these intrusions are in the form of dikes from a few inches to more than a foot thick; some of them cut the shale approximately normal to the bedding;

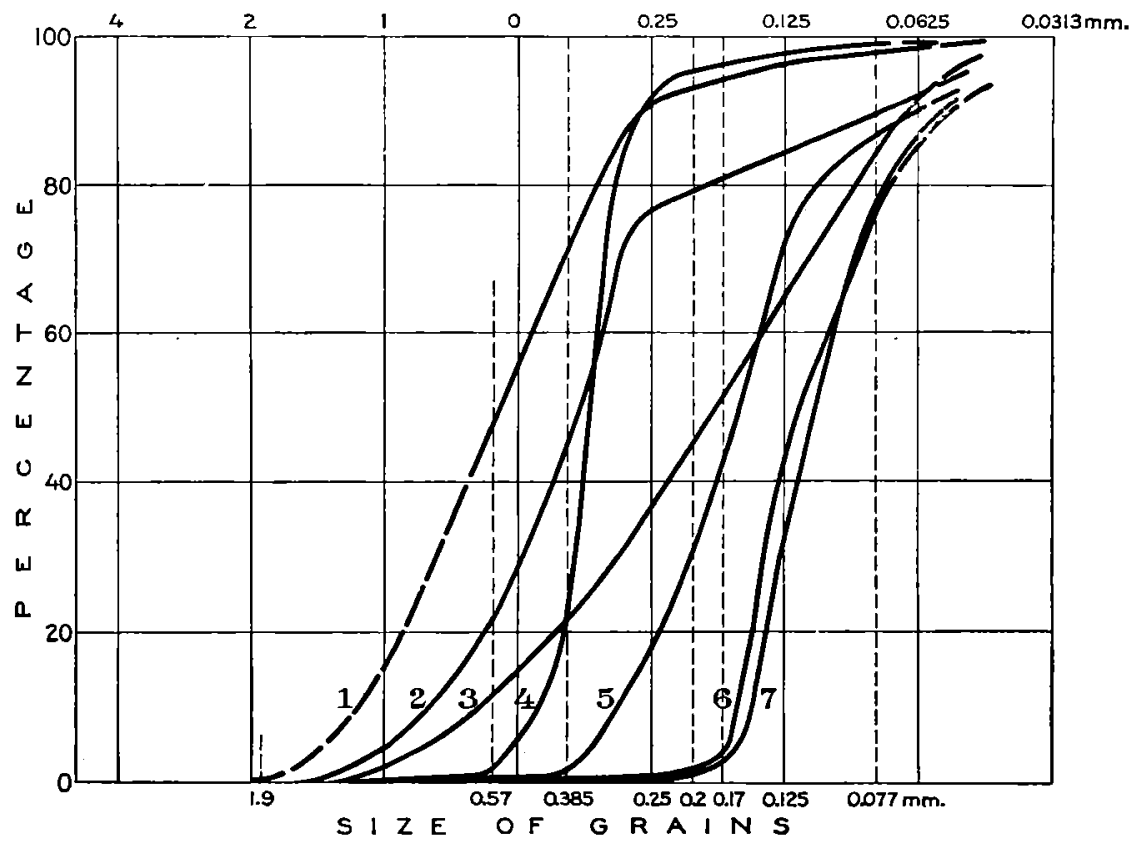

Figure 8. $\rightarrow$ Cumulative curres showing the texture and degree of sorting of some Miocene and Pleistocene sandstones. 1, Massive sandstong associated with conglomerate in Topanga formation 1,000 feet south of Topanga post office; 2, coarse gritty sandstone bed intercalated with punky diatomaceous shale, 100 feet below top of Modelo formation exposed on South Sherman Way; 3, coarse gritty sandstone of Modelo formation intercalated with thin partings of hard white platy siliceous shale containing abundant Foraminifera, near and similar to that shown in Plate $25, B ; 4$, Pleistocene marine beach sand collected from 200 to 300 toot errace along coast between Topanga and Santa Ynez Canyons; 5, fine sandstone of Topanga formation associated with thin partings of shale in Topanga Canyon, near Lida Park bridge; 6, fine sandstone from 8-inch bed in Modelo formation, collected immediately below foraminiferal shale parting at crest of GirardGarrapata Canyon road; 7 , fine sandstone intercalated rith richly diatomaceous shale of upper Modelo age from road cut $11 / 4$ miles east of Girard

others in 2-dimensional exposures appear to be sills. Plate 24, $C$, shows a rather unusual intrusive mass of light-gray sandstone which is clearly a dike at the right but which passes into a sill at the left and continues parallel to the bedding with remarkably uniform thickness for about 20 feet before it begins to pinch out. (See pl. 25, A.)

In color, hardness, texture, and mineralogy these intrusive sandstones are indistinguishable from the normal beds of sandstone that are commonly associated with shale in this part of the Modelo formation. It seems probable that they have been produced by compression of a series of shale and soft sandstone of Modelo age, by which the poorly consolidated sandstone has been forced upward along the joints and 
bedding planes of the shale. Plate $25, A$, illustrates how such an intrusion might be expected to terminate.

Shale.-The Modelo is predominantly a shaly formation, and for this reason most of it presents a strong contrast to other formations in the eastern part of the Santa Monica Mountains. The most prominent and characteristic feature of the lower member of the Modelo is the abundance of thin-bedded hard white to light-gray and light-brown platy siliceous shale in much of the area covered by its outcrop. A small amount of shale of this type occurs as thin beds associated with sandstone and conglomerate in the underlying Topanga formation, a fact which precludes the presence of such rock from serving as an infallible guide for the identification of the Modelo; but stratigraphic units of hard platy siliceous shale more than a few feet thick (such as are shown in pl. 24) are restricted to the lower member of the Modelo in the area covered by this report.

These white or nearly white siliceous shale units are everywhere beautifully bedded and, although composed predominantly of the hard platy type, contain partings and thin beds of soft earthy shale. (See pl. $25, B$.) The hard platy shale is uniformly cut by intersecting systems of joints and commonly weathers to thin rectangular chips only a few inches across. It varies considerably in hardness, some beds being chertlike in character, whereas others appear not to be so highly siliceous but are hard, compact, well consolidated, and just as distinctly bedded. Whether cherty or not, the shale commonly breaks along a conchoidal surface. The beds are generally only from 1 to 3 inches thick, and in addition they are almost invariably composed of distinct laminae so thin that 10 or 15 may be present in a thickness of 1 millimeter. (See pl. 26, A.) Shale of this type is locally rich in calcareous Foraminifera that can be readily detected with a hand lens, but the occurrence of these minute marine fossils is peculiar in that they may be and commonly are restricted to a single lamina within several feet, or perhaps tens of feet, of shale. Fish scales are abundant along many bedding planes, and even the imprints of entire fish are common in the highly fissile shale of some horizons. Isolated perfect brown casts of the leaves of land plants are locally also fairly common in foraminiferal and other beds of the lower and upper shale units. (See pl. 26,B.)

The hard white platy shale in the lower 100 feet of the Modelo and the softer brown shale in the upper part of the lower member at the west edge of the area contain soft light-gray beds of volcanic ash and bentonite from a few inches to 2 or 3 feet in thickness. The volcanic ash of samples examined is fairly uniform in having an index of refraction of 1.50 to 1.51 , which indicates a silica content equivalent to that of a granite.

Beds, lenses, and concretions of limestone weathering yellowish brown are common throughout practically all of the Modelo formation, generally with a thickness of 1 to 3 feet. Thinner beds of hard gray laminated limestone and nodular limestone are locally intercalated with the shale, and some of them contain Foraminifera in varying abundance, even in parts of the section where all other beds are apparently barren of these minute fossils.

The thin-bedded sandstone that forms a considerable part of most of the shale units shown on the geologic map, particularly in the western part of the area covered by this report, is briefly described on page 107 .

In the outcrop and hand specimen the platy shale in the lower member of the Modelo varies considerably in hardness and luster. The general appearance of the white platy shale is shown in Plate 24, $B$, and the gray, more finely banded cherty shale in Plates 24, $A$, and $26, A$. The former, although compact and hard, weathers so that it may be readily scratched with a hammer, has a dull luster and commonly an irregular fracture, and in hand specimen does not show its composition; the latter is actually a chert which rings when struck with a hammer and always has a conchoidal fracture and a somewhat vitreous luster. Thin sections reveal the fact that both of these types of hard platy shale contain opal and cryptocrystalline silica in large amounts but in different proportions. Opal, apparently the most abundant constituent in thin sections of the cherty shale, is, in contrast, not so plentiful in the noncherty variety of platy shale; although composing a large part of this rock, it is here generally associated with a much larger amount of cryptocrystalline silica.

It seems probable that to this difference in the proportions of opal and cryptocrystalline silica may in some degree be ascribed the difference in the general appearance and hardness of these two types of shale where weathering has been active. Another factor, which has been effective in some localities at least, lies in the fact that the noncherty shale commonly contains a greater number of Foraminifera and other microscopic carbonate masses.

Analyses of shale of Modelo formation [J. G. Fairchild, analyst]

\begin{tabular}{|c|c|c|c|}
\hline & 1 & 2 & 3 \\
\hline $\mathrm{SiO}_{2}$ (tot & 73. 71 & 73. 04 & 55. 80 \\
\hline $\mathrm{Al}_{2} \mathrm{O}_{3-\ldots}$ & 7. 25 & 3.58 & 4. 13 \\
\hline $\mathrm{Fe}_{2} \mathrm{O}$ & 2.63 & 1. 28 & 1. 36 \\
\hline $\mathrm{FeO}$ & .44 & .44 & .44 \\
\hline $\mathrm{MgO}_{-}$ & 1. 47 & 8.45 & 18.50 \\
\hline $\begin{array}{l}\mathrm{CaO}_{-} \\
\mathrm{Na}_{2} \mathrm{O}_{-}\end{array}$ & $\begin{array}{l}\text { 1. } 72 \\
1.19\end{array}$ & 0.00 & $\begin{array}{r}10.14 \\
.40\end{array}$ \\
\hline $\mathrm{K}_{2} \mathrm{O}$ & 1. 00 & .55 & .75 \\
\hline $\mathrm{H}_{2} \mathrm{O}-$ & 2.88 & 2. 82 & 2. 58 \\
\hline $\mathrm{H}_{2} \mathrm{O}+$ & 6. 94 & 2. 69 & 3. 02 \\
\hline $\mathrm{TiO}_{2}$ & .50 & .30 & .25 \\
\hline $\mathrm{CO}_{2--}$ & Trace? & 5. 96 & 12. 81 \\
\hline${ }_{2} \mathrm{O}_{5-\ldots} \ldots$ & & & .24 \\
\hline $\mathrm{O}_{3}$ & .16 & .05 & Trace? \\
\hline rganic carbc & 1001 & .10 & .16 \\
\hline Soluble $\mathrm{SiO}_{2}\left(5\right.$ per cent $\left.\mathrm{Na}_{2} \mathrm{CO}_{3}\right)$ & $\begin{array}{r}100.13 \\
4.46\end{array}$ & $\begin{array}{r}100.43 \\
17.22\end{array}$ & $\begin{array}{r}100.58 \\
18.52\end{array}$ \\
\hline
\end{tabular}

1. White diatomaceous shale from road near Hollywood Country Club; 40 grams. 2. Cherty shale 1 foot above volcanic ash bed on Mulholland Highway; and about 50 feet above base of upper shale member of lower part of the Modelo; 150 grams. 300 grams. 
In addition to the large amounts of silica samples 2 and 3 contain considerable calcium carbonate-13.5 and 29.1 per cent, respectively. Much of this calcium carbonate is present as calcite in abundant shells of Foraminifera.

The distinct banding so apparent in some hand specimens and in most thin sections is due to alternations of several types of material with essentially colorless opal or cryptocrystalline silica. Most of the sections of cherty shale show alternations of opal and cryptocrystalline silica with wavy bands of two different substances, the more common one a white cloudy opaque mass and the other a speckled brown which varies considerably in intensity of color. Even with an immersion lens the character of the white opaque substance can not be satisfactorily determined. There is some suggestion that it also is largely opal and that its cloudiness is due to the presence of fine closely bunched particles of clay too small to be resolved with the ordinary petrographic microscope. The brown substance has the distribution and appearance of organic matter and is assumed to be such, there being a striking contract between it and less numerous bands of iron oxide, which, in reflected light, are reddish brown and commonly are associated with grains of magnetite.

In some thin sections of the noncherty type of shale opal bands alternate with colorless carbonate bands of about equal thickness, an association which, in some places at least, is in part the cause of the greater softness of this rock. Another type of banding is produced by the presence here and there of laminae of fine sandstone or silt composed largely of angular wellsorted detrital grains of quartz and feldspar. Such laminae are usually thicker than associated siliceous bands formed by chemical precipitation, some of them having been observed to be over 4 millimeters thick.

Measurements of several series of bands in different slides show that the average thickness for a pair of bands-that is, one opal band and an adjoining brown organic band or colorless carbonate band-is approximately 0.15 millimeter. These measurements have been taken in selected areas of the thin sections where banding is most distinct and continuous.

Both the cherty and noncherty types of hard platy siliceous shale in the lower member of the Modelo commonly contain abundant well-preserved calcareous Foraminifera. These occur embedded in bands of every character, whether opal, cryptocrystalline silica, brown organic matter, reddish-brown iron stain, or carbonate, but because of the predominance in these shales of opal and cryptocrystalline silica, these substances most commonly incase the Foraminifera. Siliceous organisms, such as Radioloria, diatoms, and sponges, are invariably scarce or totally absent from the many microscopically examined samples of all types of shale from the lower member of the Modelo. All these organisms are, however, commonly present in small numbers in the cherty and noncherty shale.

Bituminous shale.-The basal portion of the Modelo formation contains at least one unit of highly bituminous black or dark brownish-gray shale. Exposures of shale of this type at approximately the same stratigraphic horizon occur in the west wall of Stone Canyon west and northwest of the reservoir, and at a point $1 \frac{1}{2}$ miles from the coast about 2,000 feet up the small canyon west of Will Rogers's ranch which joins Rustic Canyon at the Beverly Boulevard. Much of the Modelo shale exposed along the Coast Highway about half a mile east of the mouth of Santa Ynez Canyon is of this same type and may also belong to the lowest few hundred feet of the formation. In 1908 Arnold and Johnson ${ }^{40}$ investigated a reported volcano in this last-mentioned area and found that the report was due to the burning of this bituminous Miocene shale, which, they believed, had been ignited by lightning or spontaneous combustion.

This bituminous shale is thin bedded, hard, and compact and shows some resemblance to hard rubber. The dark color is apparent only in comparatively fresh exposures along cliffs; on węathered surfaces along gentle slopes the shale occurs as hard white chips scattered over the ground. In Stone Canyon shale of this type, with intercalated 1 to 3 foot beds of hard dense light-brown limestone, occupies the lower 75 to 100 feet of the Modelo formation and rests unconformably upon much more steeply dipping Topanga sandstone. The dark bituminous shale is beautifully laminated and spotted with thin lightgray and brown phosphatic streaks, which swell irregularly to form elongate phosphatic nodules parallel to the bedding.

Phosphorus determinations on representative samples of the limestone, light-gray nodules, and laminated shale showed $0.6,14.2$, and 2.14 per cent of phosphorus respectively. These percentages, when calculated as calcium phosphate, represent $3.0,71.0$, and 10.7 per cent of that compound.

In thin sections the dark bituminous shale of the lower part of the Modelo appears rich in disseminated dark-brown organic substances. Scattered detrital mineral grains, mostly quartz, are common and attain a maximum size of about 0.2 millimeter, although they constitute a relatively small part of the rock. Thin stringers of carbonate and stringers and lenticular bodies of finely crystalline chalcedony are conspicuous features of these thin sections. Light-brown transparent stringers and rounded masses of an isotropic substance, either collophane or some oil residue, are also common in sections of shale samples collected from the lower 6 feet of the Modelo formation in

4 Arnold, Ralph, and Johnson, H. R., The so-called volcano in the Santa Monica Mountains: Science, new ser., vol, 27, pp. 553-554, 1908. 
Stone Canyon. Only one diatom was noted in all the thin sections of this oil shale. Calcareous Foraminifera, however, are abundant in some of the sections but are totally absent from others.

It was noted in preliminary tests with solvents and by heating shale in test tubes that this basal bituminous shale member of the Modelo contains both free oil or oil residues and pyrobituminous substances. Consequently samples were submitted to E. T. Erickson, of the Geological Survey, for quantitative solvent tests and estimates of the amounts of pyrobitumens present, and to the Bureau of Mines for distillation tests to determine accurately the total combined amounts of all bituminous substances. Mr. Erickson has provided the following information:

Material extracted with chloroform from black shale of louer fart of Modelo formation

Along west side of Stone Canyon Reservoir:

Per cent

5 feet above base of formation.

0.96

15 feet above base of formation

Excavation for New Bay Club, 3,000 feet east of mouth

of Santa Ynez Canyon (2 samples from different

localities)

"From each of the samples the material extracted with chloroform was dark colored and solid at ordinary temperatures. When it was dissolved in a small quantity of benzene and then an excess of light petroleum ether (specific gravity 0.634 ) was added the characteristic precipitate was produced that is given by natural petroleum residues (particularly petroleum residues derived from asphaltic-base petroleums) when tested in like manner. Heating the precipitated material thus obtained from each sample pro- duced the characteristic intumescence that is given by the material obtained from the treatment of asphaltic-base petroleum residues with benzene and light petroleum ether.

"For each sample the shale material remaining from the chloroform-extraction test was dried free of chloroform and then tested for pyrobituminous matter by the test-tube heating method. Each test yielded a tarry oil material such as is typically given by the pyrobituminous material in oil shale. The yield of the tarry oil thus obtained from each sample was estimated to be somewhat less than 15 gallons a ton."

The Bureau of Mines made distillation tests and submitted the following determinations of total oil yields for four representative samples:

1. Sample from 18-inch bed of shale about 6 feet above base of Nodelo formation, west wall of Stone Canyon on road west of reservoir, due north of Bel Air and northwest of Beverly Hills: Oil yield, 14.5 gallons to the ton; specific gravity of oil, 0.908 .

2. Sample from 15-foot bed of black shale about 6 feet above sample 1: Oil yield, 18 gallons to the ton; specific gravity of oil, 0.902 .

3. Sample collected just above Coast Highway 4 miles northwest of Santa Monica and 3,000 feet east of the mouth of Santa Ynez Canyon: Oil yield, 8.6 gallons to the ton; specific gravity of oil, 0.905 .

4. Sample from same locality as sample 3: Oil yield, 3.1 gallons to the ton; specific gravity of oil, 0.905 .

Fossils and age.-Microscopic fossils collected from both the lower and upper members of the Modelo are listed and described on pages 112-115. Marine invertebrate fossils collected at several localities from the basal few feet of the lower member of the Models have been identified by W. P. Woodring as follows:

Fossils from the basal part of the lower member of the Modelo formation of the eastern part of the Santa Monica Mountains [Localities plotted on Plate 16. For description of localities see pp. 123-124]

\begin{tabular}{|c|c|c|c|c|c|c|c|}
\hline & 12 & 15 & 29 & 30 & 51 & 52 & 64 \\
\hline \multicolumn{8}{|l|}{$\begin{array}{l}\text { Gastropods: } \\
\text { Acmaea? sp } \\
\text { Haliotis palaea Woodring } 1 \text {. }\end{array}$} \\
\hline \multicolumn{8}{|l|}{$\begin{array}{l}\text { Tegula sp } \\
\text { Lamellibranchs: }\end{array}$} \\
\hline \multicolumn{8}{|l|}{$\begin{array}{l}\text { Navieula sp } \ldots \ldots \ldots \ldots \\
\text { Ostrea sp }\end{array}$} \\
\hline \multicolumn{8}{|c|}{$\begin{array}{l}\text { Hinnites sp } \\
\text { Lima sp. a (finely ribbed) }\end{array}$} \\
\hline \multicolumn{8}{|c|}{ Lima sp. b (coarsely ribbed) } \\
\hline \multirow{2}{*}{\multicolumn{8}{|c|}{$\begin{array}{l}\text { Mytilus cf. M. kewi Nomland } \\
\text { Cerastoderma cf. C. nuttalli (Conrad) }\end{array}$}} \\
\hline \multirow{2}{*}{\multicolumn{8}{|c|}{$\begin{array}{l}\text { Cerastoderma sp } \\
\text { Echinoids: }\end{array}$}} \\
\hline & & & & & & & \\
\hline $\begin{array}{l}\text { Astrodapsis of. A. brewerianus brewerianus (Rémond) } \\
\text { Astrodapsis cf. A. brewerianus diabloensis Kew }\end{array}$ & & & & & & $x$ & \\
\hline
\end{tabular}

The following comments are made by Doctor Woodring:

The fossils from the basal part of the Modelo formation are particularly interesting, inasmuch as "Pecten" raymondi, listed above as "Pecten" cf. P. raymondi brionianus, is the only species so far recorded from these beds." This "Pecten" is the most

1 Kew, W. S. W., U. S. Geol. Survey Bull. 753, p. 66, 1924. abundant species collected. The Haliotis is the first species of this genus found in Miocene beds on the Pacific coast, though it is recorded from Upper Cretaceous deposits near San Diego. ${ }^{42}$ The sand dollar listed as Astrodapsis cf. A. brewerianus brewerianus (Rémond) is a very small primitive Astrodapsis that has barely raised petals. The other variety, which is slightly more

12 Anderson, F. M., California Acad. Sei. Proc., 3d ser., vol. 2, No. 1, p. 75, pl. 9 fig. 183, 1902. 

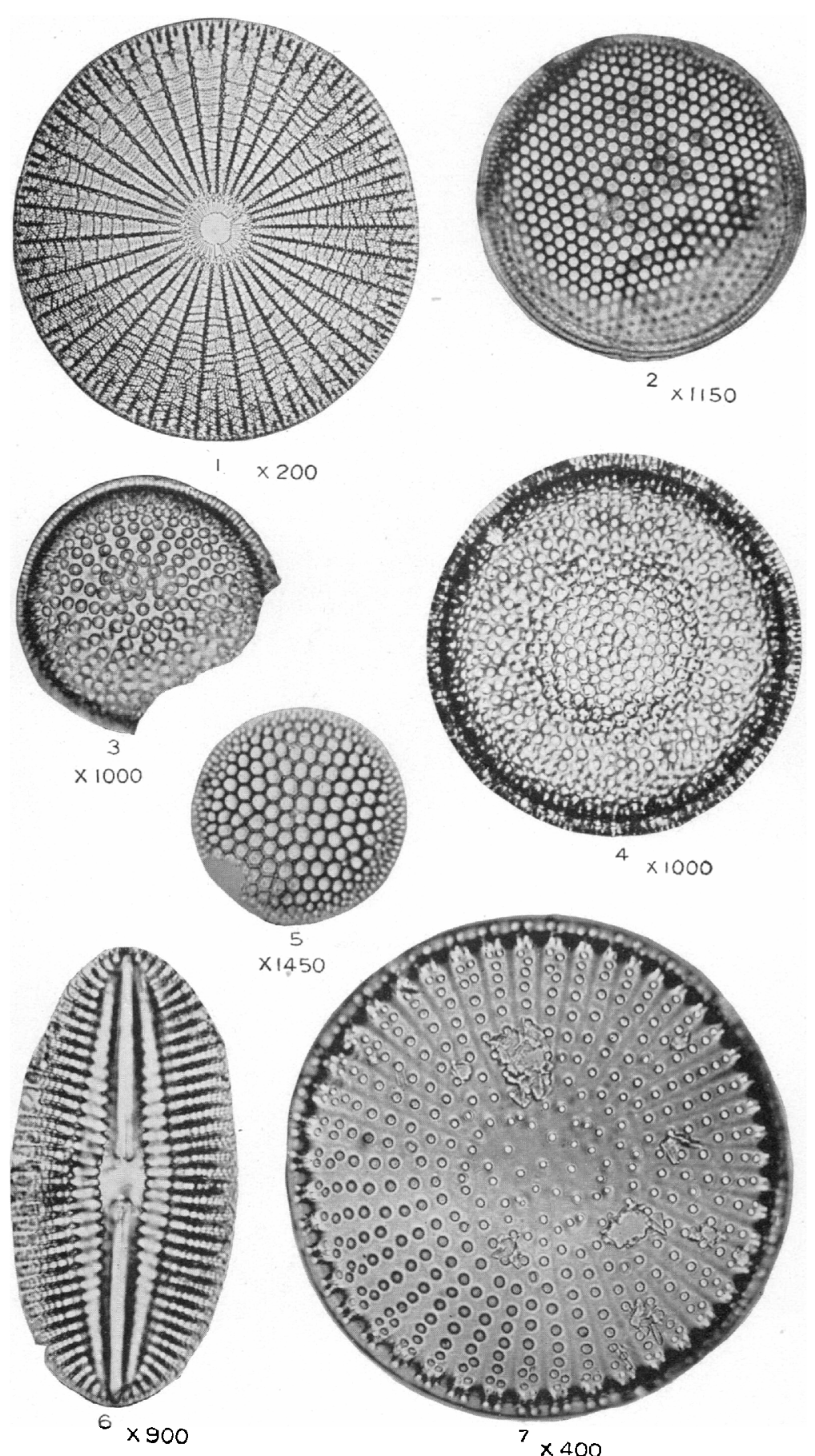

DIATOMS FROM THE UPPER MEMBER OF THE MODELO FORMA'TION, NORTH SLOPE OF SANTA MONICA MOUNTAINS NEAR GIRARD, LOS ANGELES COUNTY, CALIF.

Identifications and photographs by K. F. Lohman. For lucalities see Plate 27, C.

1. Arachnoidiscus ornatus Ehrenberg. Locality 162, about 2,900 fect above base of $\mathbf{M}$ [odelo

2. Coscinodiscus excentricus Ehrenberg. Locality 172 , about 3,360 feet above hase of Modelo

3. Coscinoriscus elegans Greville. Locality 174, about 3,420 fuet above base of Modelo forma.

4. Coscinodiscus suboculatus Rattray. tion. ${ }_{7}$, about 3,360 reet above base of Modelo

5. Coscinodiscus decrescens Grunow. Locality 172, about 3,360 feet above base of Modelo

. Jormation.

6. Diploneis smithii (Hrebisson) Cleve. Locality 165 , about 3,080 feet above base of Modelo 7. Stictodiscus californicus Greville. Locality 160 , about 2,850 leet above base of Modelo 


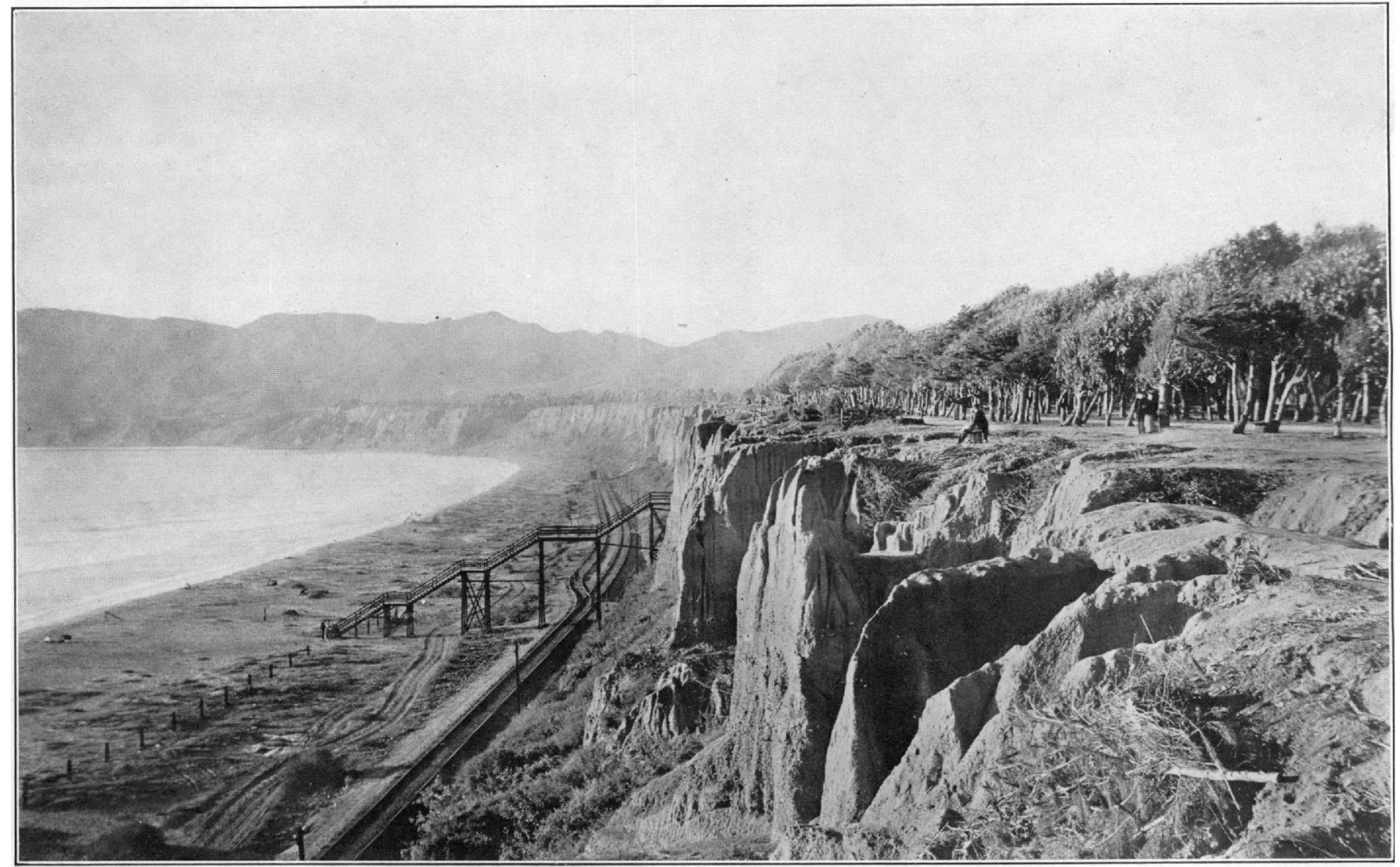

A. COASTAL BLUFFS OF PLEISTOCENE BROWN ALLUVIAL-PLAIN MATERIAL

View west from a point near mouth of Santa Monica Canyon. The bluff is about 200 feet high. Photograph by W. C. Mendenhall, 1904.

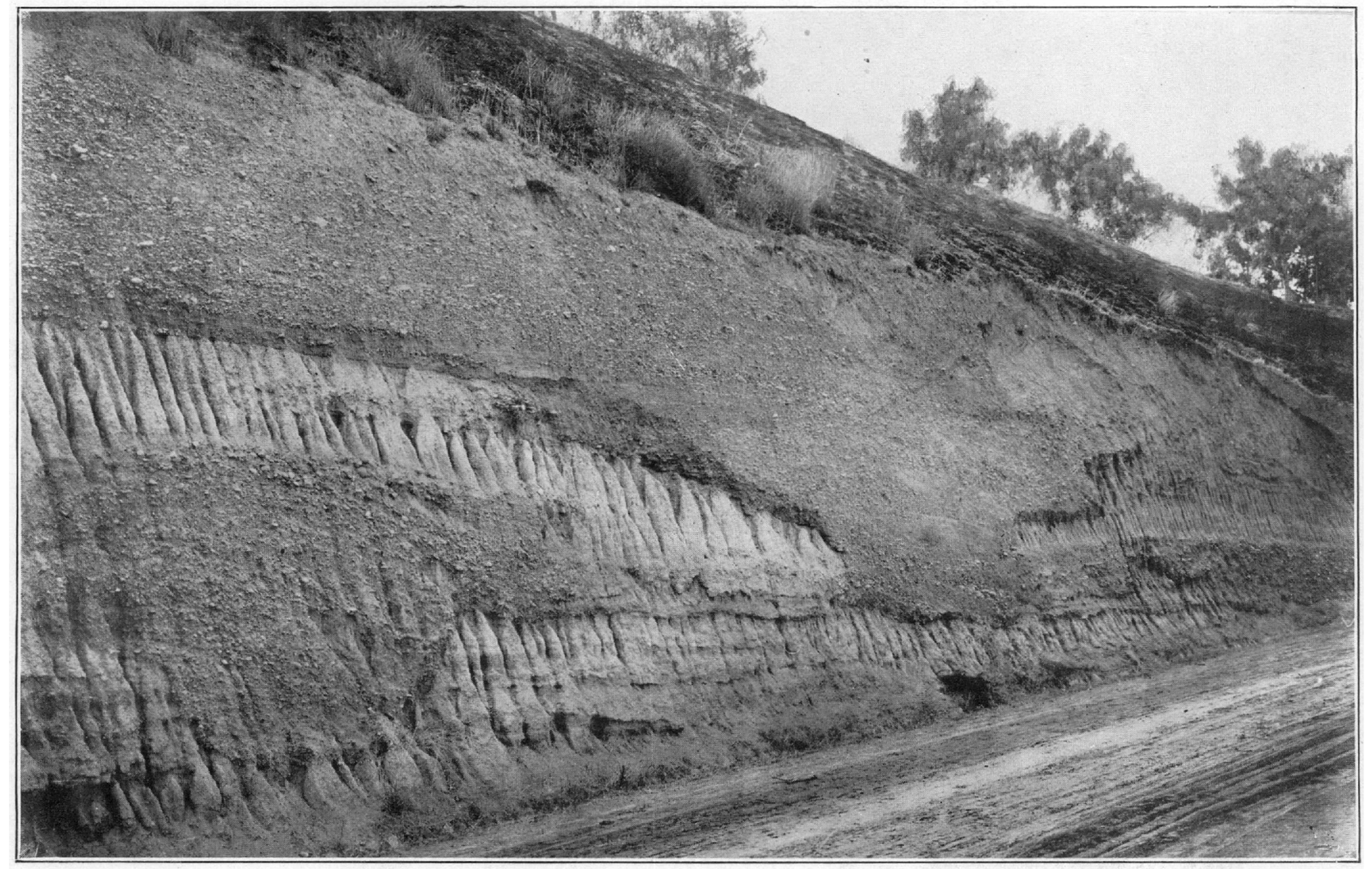

B. INDISTINCT BEDDING AND POOR SORTING COMMON IN THE PLEISTOCENE ALLUVIAL-PLAIN DEPOSITS 
advanced, is also very small but has slightly raised petals and a shallow notch in the posterior interambulacrum. Both forms of Astrodapsis are more primitive than $A$. brewerianus, and on the basis of the evidence they furnish it is concluded that the basal detrital beds of the Modelo formation are older than the Briones sandstone of the San Francisco Bay region. Inasmuch as the Briones sandstone disconformably overlies the Monterey group of the San Francisco Bay region, ${ }^{43}$ the shales of the Modelo formation in the Santa Monica Mountains seem to be younger than the Monterey deposits near San Francisco Bay, though they may in part fall at the horizon of the hiatus between the Monterey and the Briones sandstone.

The mollusks in the detrital beds at the base of the Modelo formation represent an interesting lithologic facies, for many of them are rock clingers or nest among stones. Modern representatives of limpets (Acmaea?), abalones (Haliotis), and turbans (Tegula) are found on rocks. The rock scallop (Hinnites) attaches itself to rocks, and the arks (Navicula, better known as Arca) and file shells (Lima) nest among stones. These mollusks clearly lived at the foot of rock cliffs, as might be supposed from their occurrence immediately above the irregular surface of Triassic (?) slate and schist. The rarity of rock-clinging species as fossils indicates that unusual conditions are demanded for their preservation.

Doctor Woodring has also furnished the following note on mollusks from the thin-bedded shales of the Modelo formation:

"Pecten" pedroanus (Trask) (localities 4, 11, 134, 136) and an undetermined species of Miltha? (locality 4) are the only mollusks collected from the thin-bedded shales of the Modelo formation. "Pecten" pedroanus is found in both upper Miocene and Pliocene deposits and is closely allied to a modern species. ${ }^{44}$ These small scallops probably lived on kelp. After death their thin shells may have remained suspended in the water for a long time before they finally settled to the bottom and thus were carried far and wide before they were buried. This mode of life and of distribution after death would account for their widespread distribution in these thin-bedded shales, in which hardly any other mollusks are found.

The vertebra of a whale and the first metacarpal from the right fore limb of a sea lion, the latter identified by Dr. Remington Kellogg, were collected at fossil locality 65 from a 10 -foot sandstone at the base of the lower member of the Modelo formation near the west line of the NW. $1 / 4$ sec. $33, T .1 \mathrm{~N} .$, R. $16 \mathrm{~W}$. Doctor Kellogg, although expressing some uncertainty as to the specific identification of the sea-lion bone, states that it is suspiciously like the first right metacarpal of a sea lion from the "Temblor" which he has described as Allodesmus kernensis.

A large tooth of a shark was collected from the basal sandstone bed of the Modelo formation along the southern edge of the mountains (locality 10, on Will Rogers's ranch, just west of lower Rustic Canyon).

Dr. Chester Stock has informed the writer that fragmentary fossil remains of a horse have been found in the lowest shale member of the Modelo near the head of Sepulveda Canyon. The locality is close to locality 58 shown on Plate 16. According to Doctor

\footnotetext{
49 Trask, P. D., California Univ. Dept. Geol. Sci. Bull., vol. 13, No. 5, pp. 13i-138, 1922.

"See Arnold, Ralph, U. S. Geol. Survey Prof. Paper 47, pp. 90-91, 1906. $4176^{\circ}-31-3$
}

Stock, these remains consist of carpal bones and limb elements that are similar to those of Merychippus but are of little value for age determination. They were found in marine sediments associated with fossil fish and the leaves of land plants.

Leaves of land plants (pl. 26, $B$ ) were found in foraminiferal platy shale in the upper part of the lower member of the Modelo formation on the Mulholland Highway at locality 57. According to Dr. Ralph W. Chaney, these leaves belong to Platanus dissecta, the most characteristic species of the Miocene in western America and a common member of the flora of the upper part of the San Pablo formation. Doctor Chaney states that conditions in general during Miocene time were favorable for the preservation of the remains of river-border species.

\section{UPPER MEMBER}

General features.--The upper member of the Modelo formation is composed to a large extent of soft white punky diatomaceous shale. Its exposure is restricted to the northern edge of the Santa Monica Mountains west of Universal City, and all the good outcrops lie south of the Ventura Boulevard. In the eastern part of its exposure, east of the Encino Reservoir, this member is consistent in that it is made up in greater part of diatomaceous shale and contains no prominent beds of sandstone. Farther west, however, the lower part of this punky diatomaceous shale grades westward into ordinary brown earthy shale and fine brown sandstone, so that the contact between the upper and lower members of the Modelo near Girard is not drawn at the base of the diatomaceous shale but at a horizon which is equivalent to this striking change in lithology in the area farther east. A section of the upper and lower members of the Modelo has been measured near the western edge of the area near structure section line $\mathrm{A}-\mathrm{A}^{\prime}$ (pl. 16) and appears on pages 103-104. From this it will be noted that the characteristic punky diatomaceous shale does not occur in the lower part of the upper member but makes its first appearance about 1,100 feet above the base and is a prominent constituent of the upper part.

Plate 25, $C$, shows an exposure of the diatomaceous shale just south of the Ventura Boulevard a quarter of a mile east of Girard. Shale of this type is remarkably well bedded and is composed of distinct laminae and thin beds of light-gray and brown color. In other exposures thin beds are not so regular and continuous and there are strong indications of scouring action, presumably by waves or currents along the sea bottom. Bedding planes generally reveal multitudes of tiny white disk-shaped tests of marine diatoms, together with fish scales and, occasionally, the small, thin, nearly transparent shells of "Pecten" pedroanus Trask, the only megascopic invertebrate fassil found in the upper member of the Modelo. Fragments of 
silicified and lignitized wood are also locally present. Other than the diatoms the most abundant microscopic fossils are Radiolaria, Foraminifera, sponge spicules, and silicoflagellates. Calcareous Foraminifera are not as common as in the lower member of the Modelo, but in some thin beds or partings wellpreserved forms representing several dozen species occur by the millions.

This member contains numerous thin beds of lightgray volcanic ash, similar in index of refraction to that in the lower member of the Modelo, and lenses and beds, as much as 3 feet thick, of hard limestone that weathers yellowish brown.

The contact between the lower and upper memoers of the Modelo is well exposed in several road cuts that connect the Mulholland Highway with the Ventura Boulevard, and except for the occurrence at one locality of a 1-inch bed of conglomerate suggestive of a local break in sedimentation and minor erosion this contact is apparently one of conformable stratigraphic relations. For instance, on the road leading north up the short ridge just east of the Hollywood Country Club punky diatomaceous shale of the upper member grades downward into hard brown platy shale of the lower member through a stratigraphic interval of 30 feet occupied by alternating thin beds of white punky diatomaceous and hard brown platy shale. The 1-inch bed of conglomerate occurs here within this gradational sequence.

Figure 8 shows the results of mechanical analyses of two sandstone samples collected from different thin beds intercalated with the finely laminated punky diatomaceous shale of this member. The finer sample, illustrated by curve 7 , is more representative of the character of the sandstone associated with this shale. The presence of these intercalated sandstone beds is in itself important in providing evidence that these diatomaceous deposits accumulated on the continental shelf at depths where currents or waves were capable of moving bottom sediment. According to Barrell, ${ }^{45}$ wave base, or the depth at which wave action ceases to be strong enough to transport bottom sediment, is generally 50 fathoms in the ocean. Currents, however, according to several investigators cited by Twenhofel,$^{46}$ are in some places sufficiently strong to transport sand at depths of 250 meters (about 137 fathoms). It seems probable that such sand would be fine and fairly well sorted as to size of grains, like the sample represented by curve 7 in Figure 8 . However, the coarseness and rather poorly sorted character of the sample represented by curve 2 suggests that some of these diatomaceous deposits accumulated at depths considerably less, possibly less than 50 fathoms. The probability of a shallow-water origin for at least some diatomaceous deposits is also supported by the recent

45 Barrell, Joseph, Rhythms and the measurements of geologic time: Geol. Soc. America Bull., vol. 28, p. 778, 1917.

6 Twenhofel, W. H., Treatise on sedimentatios, pp. 474-475, 1926. discovery of diatom epidemics off the coast of Washington. ${ }^{47}$

Microscopic character of shale.-In thin sections the diatomaceous shale of the upper member of the Modelo, except for the abundance of the opaline tests of diatoms and various kinds of spicules, appears much like the hard platy shale in the lower member of this formation. Cryptocrystalline silica, however, composes most of the groundmass, there commonly being a much smaller proportion of true opal. In most of the thin sections banding is not so distinct in this shale, the most common type of which is produced by the presence, locally in considerable abundance, of thin cloudy, nearly opaque bands which are white in reflected light and which alternate with more nearly transparent bands of cryptocrystalline silica. Other banding results from the presence in some sections of pale-brown bands containing a small amount of organic matter, and, less commonly, the presence of thin colorless bands of opal or of thicker bands which consist largely of angular detrital grains of quartz and plagioclase feldspar as much as 0.10 to 0.15 millimeters in diameter. Most of the diatomaceous shale contains detrital mineral grains of about this maximum size scattered throughout the groundmass of cryptocrystalline silica. Green and brown flakes of chlorite and biotite are abundant along some of the bedding planes.

Some sections are literally flooded with entire and broken tests of diatoms and spicules of sponges and Radiolaria. Radiolaria are generally common, but in none of the thin sections of the punky diatomaceous shale are they nearly as abundant as the diatoms. Small rounded or oblong bodies which appear to be sponge globules are abundant in some sections. Calcareous Foraminifera, associated with more abundant diatoms, make up a considerable part of some of the sections and have been found to be abundant in laminae of some of the shale outcrops. Other calcareous shells, invariably flattened and crushed, with elongation parallel to the bedding, are also very common and materially assist in accentuating banding in some of the sections. These shells are indeterminable, but probably are the fossil remains of pelecypods, inasmuch as such shells have been observed along bedding planes in hand specimens.

Fossils and age.-Foraminifera collected from both the lower and upper members of the Modelo, as exposed in the western part of the area along the road between Girard and Garrapata Canyon (localities 111-174), have been prepared and identified by W. D. Rankin, of Los Angeles. In order to obtain a check upon his results, Mr. Rankin submitted his prepared material to D. D. Hughes and P. P. Goudkoff for examination. The identification and distribution of the numerous species of Foraminifera are presented in the following table, prepared by Mr. Rankin:

"i Becking, L. B., Tolman, C. F., McMillin, H. C., Field, John, and Hashimoto, T., Preliminary statement regarding the diatom "epidemies" at Copalis Beach, Washington, and an analysis of diatom oil: Econ. Geology, vol. 22, pp. 356-368, 1927. 
Distribution of Foraminifera throughout section of Modelo formation exposed along road between Girard and Mohn Springs

[Prepared by W. D. Rankin. /, very rare; + , rare; $X$, fairly common; $O$, common; $\bullet$, abundant. For localities and stratigraphic position of samples see pl. 27, A, C.]

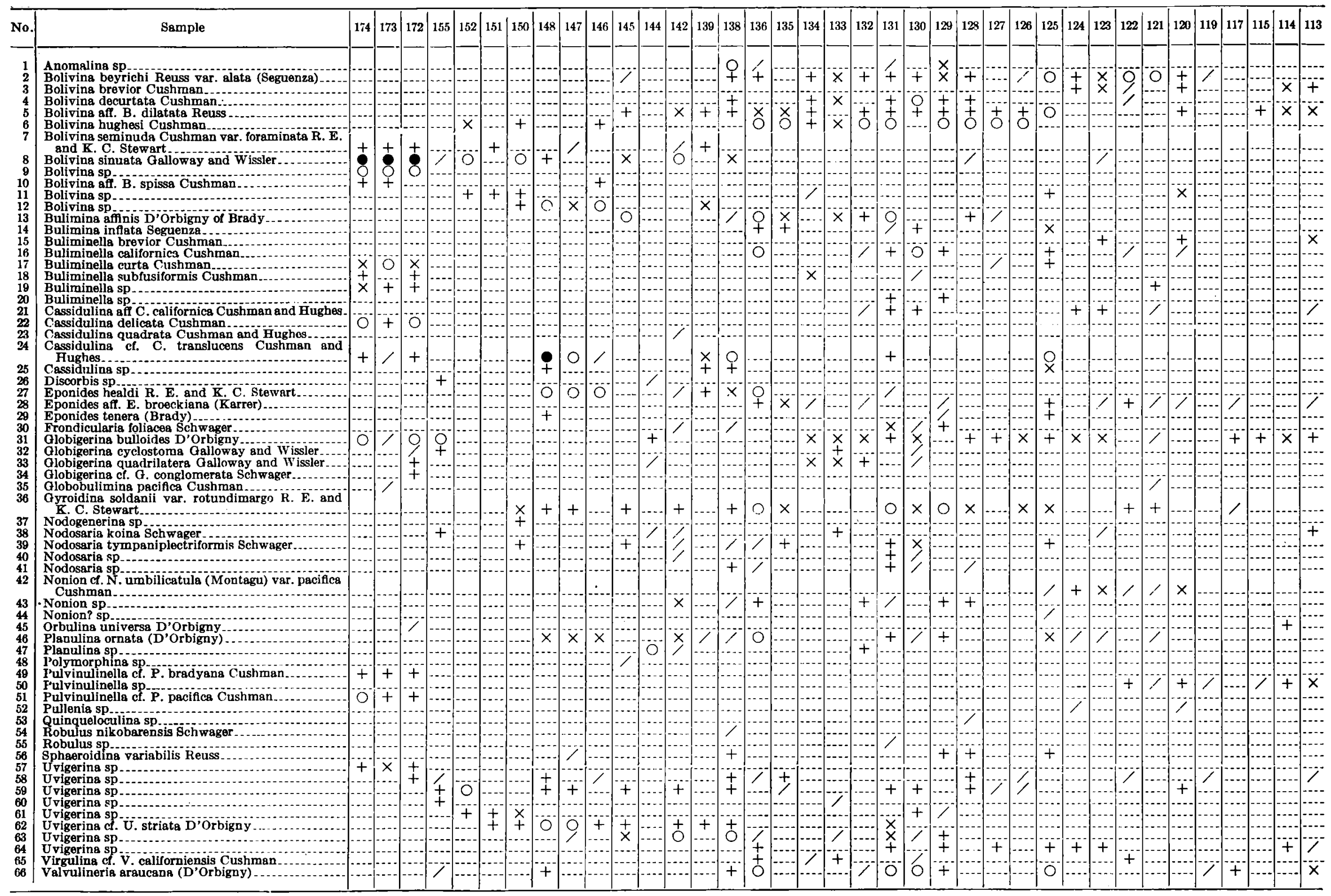


Mr. Rankin's conclusions, concurred in by Messrs. Hughes and Goudkoff, are as follows:

The foraminiferal fauna of the lower member of the Modelo is characterized by an assemblage of such species as Bolivina beyrichi Reuss var. alata (Seguenza), Bolivina hughesi Cushman, Bolivina decurtata Cushman, Bolivina aff. B. dilatata Reuss, Bulimina affinis D'Orbigny of Brady, Buliminella californica Cushman, Buliminella sp., and Eponides aff. $E$. broeckiana (Karrer). This fauna has been found in the upper shale member of the Puente formation as exposed in La Habra Canyon on the south flank of the Puente Hills.

The foraminiferal fauna of the upper member of the Modelo, as found in collections 172,173 , and 174 , is characterized by an assemblage of such species as Bolivina seminuda Cushman var. foraminala R. E. and K. C. Stewart, Bolivina sinuata Galloway and Wissler, Bolivina aff. B. spissa Cushman, Bolivina sp., Buliminella sp., Cassidulina delicata Cushman, Pulvinulinella bradyana Cushman, and Pulvinulina cf. $P$. pacifica Cushman. This fauna may be the age equivalent of the upper shale member of the Modelo as mapped by Kew in Modelo Canyon, a stratigraphic zone which directly underlies shale considered by Hudson and Craig to be of Santa Margarita age. The faunas of these two widely separated areas of upper Miocene rocks have noteworthy affinities; the upper shale member of the Modelo of Modelo Canyon, however, contains arenaceous Foraminifera which were not detected in the upper Modelo of the Girard area.
Samples collected from localities 303, 304, and 107 in Potrero Canyon, along the coast near Santa Monica, came from small fault blocks of Modelo shale and, according to Goudkoff, Hughes, and Rankin, contain Foraminifera which permit them to be correlated with the middle part of the lower member of the Modelo. Samples 104 and 105, obtained near the mouth of Temescal Canyon, contain no distinctive fossils, but sample 106, from the same area, contains a fauna which Rankin says belongs to the lower member of the Modelo. The sample from locality 110 , near the base of the Modelo on the south flank of the mountains half a mile north of the Beverly Hills Hotel (see pl. 16), likewise contains a foraminiferal fauna which, according to Rankin, may be correlated with the lower member of the Modelo in the Girard and Garrapata Canyon section.

A duplicate suite of samples from the Girard and Garrapata Canyon section of the Modelo was examined for diatoms by K. E. Lohman, of the California Institute of Technology. Mr. Lohman has prepared the following table showing the names and distribution of diatoms found in this section, also. Plate 28, showing several of the species of diatoms.

Modelo diatoms from road leading south from Ventura Boulevard on first ridge east of Girard

[Identifed by K. E. Lohman. For localities and stratigraphic position of samples 160-174 see pl. 27, A, C. /, very rare; + , rare; $X$, fairly common; $O$, common; , abundant]

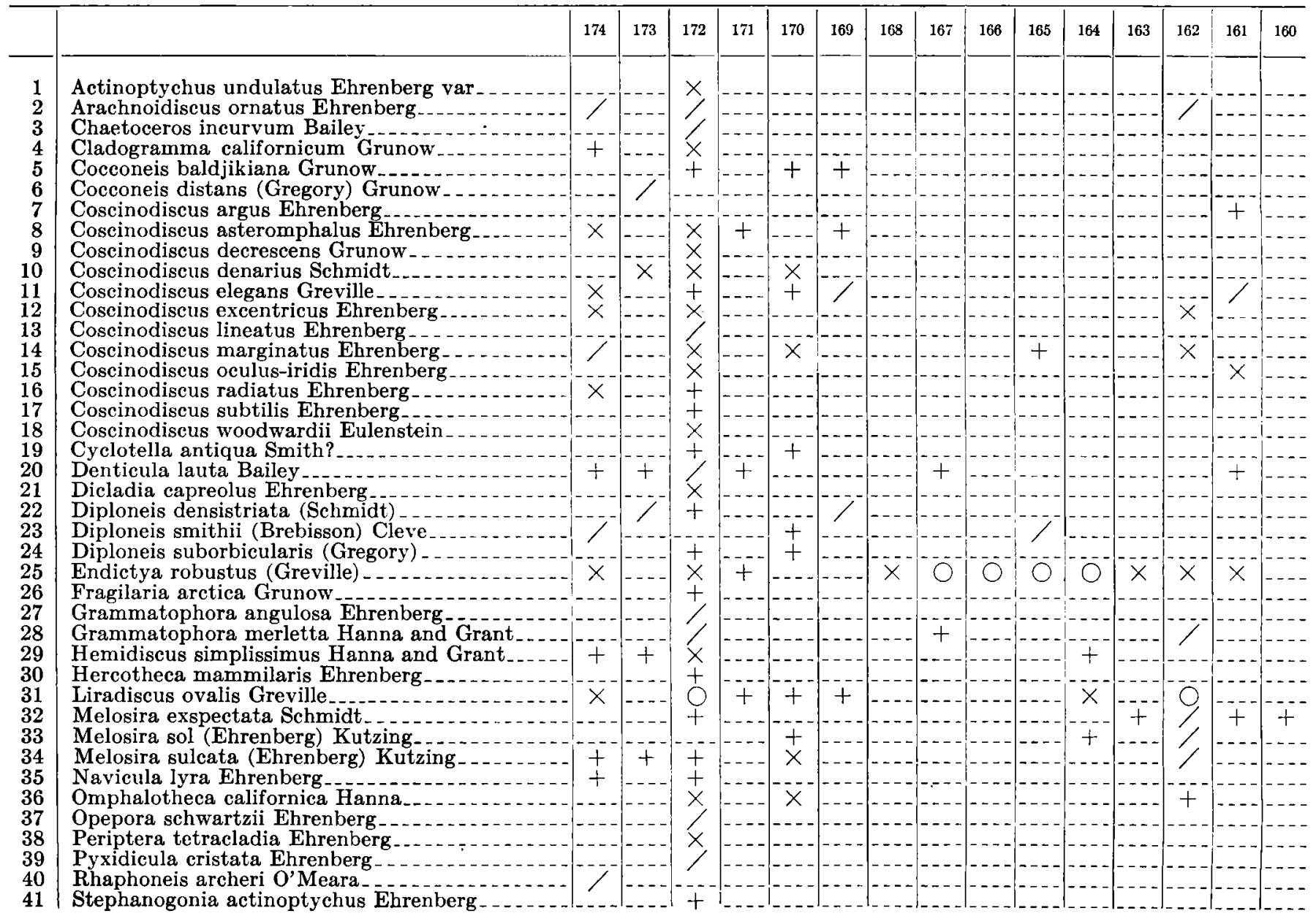


Modelo diatoms from road leading south from Ventura Boulevard on first ridge east of Girard-Continued

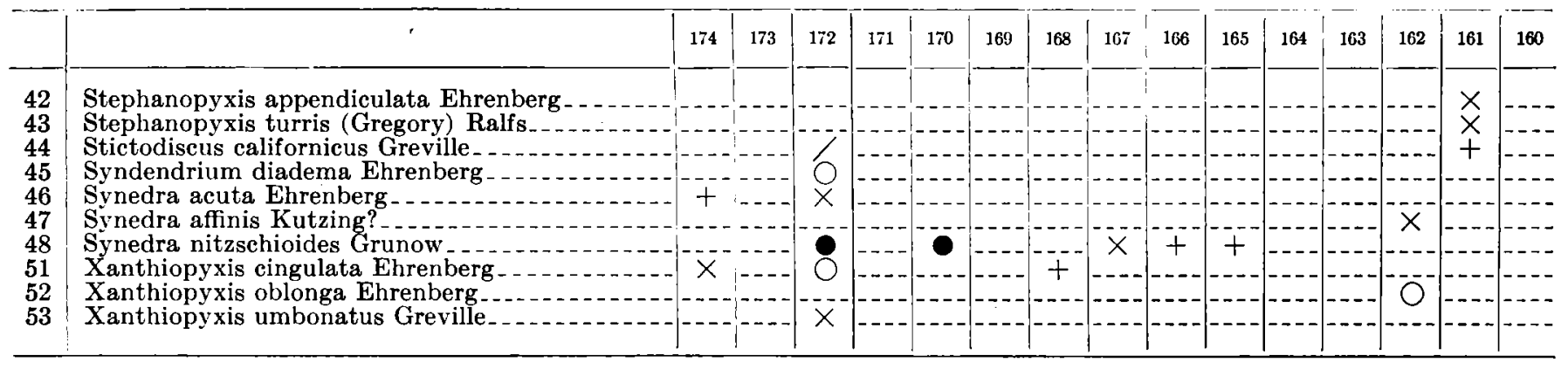

The following statements are made by Mr. Lohman:

No diatoms were found in the lower 2,850 feet (between samples 111 and 159). Beginning with No. 160, however, where one diatom was found, and continuing through to No. 174, the highest sample collected, diatoms were found consistently. Samples 155 to 174 all contained sponge spicules, Radiolaria, and silicoflagellates.

Endictya robustus (Greville) was the first diatom to become fairly common in going up in the section; it became common in samples 164 to 167 , and then less common in succeeding samples.

In samples 163 to 168 very little diversity of form of the diatoms was noted, there being only two or three species present in any amounts above rare. Samples 169 and 170 showed a considerable increase in diversity, but sample 171 contained relatively few species and individuals. In sample 172 , however, a very great and sudden increase to 45 species was observed, of which 1, Synedra nitzschioides Grunow, is abundant; 3, Xanthiopyxis cingulata Ehrenberg, Syndendrium diadema Ehrenberg, and Liradiscus ovalis Greville, are common; and 17 are fairly common. Sample 173 showed a decided decrease in number of species as well as in abundance, there being only 6 species reported. Sample 174, the last collected, although very diatomaceous, has only 17 species. This great fluctuation has two possible explanations. Either it represents a change in the actual deposition of the organisms, or it means that the samples are not truly representative.

In general the diatom flora in this section is characterized by small forms, many of which are broken. It is nothing like the flora from the "Temblor" formation of Shark Tooth Hill, nor is it like Monterey from the type locality.
In addition to the species listed in the table, there are other species, such as Coscinodiscus suboculatus Rattray, illustrated in Plate 28, and several species which are thought to be new.

\section{PLIOCENE ROCKS}

Rocks of Pliocene age are absent in surface outcrops over most of the area covered by this report, being exposed only in the coastal belt that lies south of the mountains and northwest of the city of Santa Monica. They are probably very extensive beneath the alluvial plains that border the mountains on the south and on the north, for they not only crop out in the Baldwin Hills and in isolated patches south of the mountains and in the City of Los Angeles, but have been penetrated by wells drilled in the Inglewood (Baldwin Hills), Beverly Hills, and Salt Lake oil fields and by scattered wildcat wells of the adjoining lowlands.

It is impossible to determine from the field relations the relative age of most of the isolated sections of Pliocene and Pleistocene rocks exposed in the coastal areas north and northwest of Santa Monica. According to W. P. Woodring's interpretation of the evidence provided by megascopic fossils from beds of these areas, the stratigraphic order for the marine Pliocene and Pleistocene of this region that contain such fossils is as follows:

Age and stratigraphic order of marine Pliocene and Pleistocene rocks

[Based entirely on fossil evidence obtained by W. P. Woodring. For fossil localities see pp. 123-124 and pl. 10]

\begin{tabular}{|c|c|c|}
\hline Age & Locality & Correlation \\
\hline Late Pleistocene & $\begin{array}{l}\text { Overland Avenue (locality 68); upper Potrero Can- } \\
\text { von (locality 61) }\end{array}$ & Upper San Pedro. \\
\hline $\begin{array}{l}\text { Lower Pleistocene or upper Plio- } \\
\text { cene. }\end{array}$ & $\begin{array}{l}\text { Conglomerate at mouth of Potrero Canyon (locality } \\
\text { 31); storm-drain ditch in Rustic Canyon (locality } \\
\text { 311). }\end{array}$ & $\begin{array}{l}\text { Cool-water fauna of Timms Point and } \\
\text { Deadman Island. }\end{array}$ \\
\hline Upper Pliocene & Upper part of Potrero Canyon section (locality 61A) - & $\begin{array}{l}\text { "Arca" camuloensis fauna of Los An- } \\
\text { geles Basin and Santa Clara Valley }\end{array}$ \\
\hline Middle or upper Pliocene & Temescal Canyon (locality 55) - - & San Diego fauna. \\
\hline
\end{tabular}

All the Pliocene rocks from which megascopic fossils were collected in this area are considered by Woodring to be younger than the Pliocene beds of Elsmere Canyon (lower Pliocene) in Ventura County. According to foraminiferal evidence obtained by D. D. Hughes and P. P. Goudkoff from Potrero Canyon there are also beds in this area which are of lower Pliocene age but these beds contain no megascopic fossils.

\section{POTRERO CANYON}

Most of the exposed Pliocene section occurs in and near Potrero Canyon, near the northwestern edge of 
Santa Monica. It is fairly uniform throughout and is composed of soft medium to dark gray clay shale and sandy clay shale which are rich in well-preserved shells of calcareous Foraminifera. This section has a maximum exposed thickness of about 1,000 feet. Bedding appears to be fairly distinct, but the rock lacks the firm, thin-bedded, highly fissile character common to the Miocene shales of this district. Lenses and beds of hard gray and yellowish-brown limestone are scattered throughout the clay shale, and beds of breccia have been noted which are composed of angular fragments of limestone that apparently have been derived from the underlying Miocene. These Pliocene rocks are faulted against Modelo shale at several places in Potrero Canyon.

The upper part of this section is equivalent to a part of the Pico formation at its type locality in Pico Canyon. The lower part is equivalent to foraminiferal lower Pliocene beds in Ventura and Los Angeles Counties which, in areas distant from the type section of the Pico formation, are known to underlie the Pico formation and overlie Miocene strata. The type Pico is now considered by many active workers in California stratigraphy and paleontology to be of upper Pliocene age, and the underlying Pliocene rocks to be of lower Pliocene age. For these stratigraphically lower Pliocene strata, which were not included by Kew ${ }^{48}$ in the type section of the Pico, and, according to some paleontologists, for some additional overlying beds that occur in the lower part of the type section of the Pico, Eaton ${ }^{49}$ has suggested the name Santa Paula formation.

Another exposure of Pliocene sandy gray clay shale occurs on the coast just west of the mouth of Potrero Canyon. This shale dips $20^{\circ}-30^{\circ} \mathrm{SE}$. and appears to rest directly upon vertical or nearly vertical brown Miocene shale in the bluff at the western edge of the exposure. It is possible, however, that the apparent relations have resulted from displacement along a westward extension of the fault that cuts across Potrero Canyon only a few hundred feet above its mouth. (See pl. 16.) At the mouth of this canyon almost horizontal marine upper Pliocene or lower Pleistocene beds are faulted down against tilted lower Pliocene clay shale.

The following fossils were collected at the top of the northward-dipping section of Pliocene clay shale near the head of Potrero Canyon (locality 61A) a quarter of a mile south of Pacific Palisades post office. The bed from which they came occurs directly beneath soft white flat-lying sand of Pleistocene age that also carries a rich marine invertebrate fauna. W. P.

\footnotetext{
${ }^{18} \mathrm{Kew}$, W. S. W., Geology and oil resources of a part of Los Angeles and Ventura Counties, Calif.: U. S. Geol. Survey Bull. 753, p. 70, pl. 1, 1924.

in Eaton, J. E., The Fersand group of southern California, paper read before the Pacifle section of Am. Assoc. Petroleum Geologists at Los Angeles Oct. 29, 1926. Eaton later used this formation name in the following publications: Ventura field controlled reservoirs: Oil and Gas Jour., Nov. 11, 1926, p. 72; The by-passing of discontinuous deposition of sedimentary materials: Am. Assoc. Petroleum Geologists Bull., vol. 13, No. 7, fig. 10, 1929.
}

Woodring has identified these Pliocene fossils, as follows:

Bryozoon:

Cellaria sp.

Gastropods:

Calliostoma canaliculatum (Martyn)?

Calliostoma costatum (Martyn).

Homalopoma paucicostata fenestrata (Bartsch).

Turbonilla, $3 \mathrm{spp}$.

Odostomia sp.

Epitonium sp.

Tectonatica clausa (Broderip and Sowerby).

Neverita recluziana (Deshayes).

Crepidula onyx Sowerby.

Alvania sp.

Lacuna sp.

Turritella, 2 spp.

Bittium, 3 spp.

Tritonalia barbarensis (Gabb).

Tritonalia cf. T. lurida (Middendorf).

Boreotrophon ef. B. orpheus (Gould).

Boreotrophon sp.

Mitrella carinata (Hinds).

Mitrella tuberosa (Carpenter).

Amphissa sp.

Nassarius perpinguis (Gould)?

Nassarius insculptus (Carpenter).

"Cantharus" fortis (Carpenter).

Barbarofusus traski (Dall).

Olivella biplicata Sowerby.

Admete sp.

Conus californicus Hinds.

Antiplanes perversa (Gabb).

Antiplanes pedroana (Arnold).

Mangilia sp.

Philbertia sp.

Lora sp.

Acteon ef. A. punctocoelatus (Carpenter).

Scaphopods:

Dentalium neohexagonum Sharp and Pilsbry.

Dentalium sp.

Cadulus fusiformis Pilsbry and Sharp?

Cadulus ef. C. californicus Pilsbry and Sharp.

Lamellibranchs:

Saccella taphria (Dall).

Nuculana sp.

Yoldia sp.

"Pecten" cerrosensis Gabb.

"Pecten" latiauritus Conrad.

"Pseudamusium" sp.

Hinnites sp.

Crenella sp.

Cyclocardia ventricosa (Gould).

Thyasira sp.

Thyasira gouldii (Philippi).

Axinopsis viridis Dall.

Lucinoma annulata (Reeve).

Parvilucina tenuisculpta (Carpenter).

Rochefortia sp.

Trachycardium quadrigenarium (Conrad).

Chione sp.

Venerupis cf. V. staminea (Conrad).

Psephidia ovalis Dall.

Psephidia cymata (Dall)?

Tellina sp.

Macoma sp.

Solen sicarius Gould?

Corbula luteola Carpenter.

Panope generosa Gould. 
Doctor Woodring has contributed the following statement regarding this collection:

This fauna is considerably younger than the San Diego fauna and probably is of about the same age as the "Arca" multicostata or "Arca" camuloensis fauna found in the Puente Hills, ${ }^{\text {b0 }}$ in the Los Angeles Third Street tunnel, ${ }^{, 11}$ and in the Santa Clara Valley." Like the "Arca" camuloensis fauna, it embraces species of warm-water facies ("Cantharus" fortis, "Pecten" cerrosensis, Parvilucina tenuisculpta, Trachycardium quadrigenarium, Chione, Corbula luteola) and also a few species of cool-water aspect (Boreotrophon, Lora, Thyasira). It is regarded as heralding the approach of a cooler climate, but not so cool as that of the fossils found in the excavation for the Richfield Oil Co.'s building at Sixth and Flower Streets and in the bluff on Fifth Street between Grand and Flower Streets, both in Los Angeles. On an assumption of progressive lowering of temperature during the later part of Pliocene time the fauna from Potrero Canyon is older than the fossils in Los Angeles just mentioned. This age assignment is substantiated by the presence of at least one distinctive extinct San Diego species-"Pecten" cerrosensis Gabb ("ashleyi Arnold"). Others (Ostrea "veatchii" and "Pecten" healeyi) are recorded from the "Arca" camuloensis fauna.

P. P. Goudkoff, Boris Laiming, and D. D. Hughes have examined for Foraminifera samples collected in Potrero Canyon and in other areas in the vicinity of Santa Monica. (See pl. 27, B.) They have identified the species present and have prepared the following table:

Foraminifera collected from Miocene, Pliocene, and Pleistocene formations near Santa Monica, Calif.

[Identifications and age determinations by P. P. Goudkoff, Boris Laiming, and D. D. Hughes. Localities are plotted on pl. 27, B, and described on p. 124. a, Abundant;
c, common; $r$, rare]

\begin{tabular}{|c|c|c|c|c|c|c|c|c|c|c|c|c|c|}
\hline & 311 & 312 & 310 & 309 & 308 & 307 & 306 & 305 & 302 & 301 & 303 & 304 & Age \\
\hline $\begin{array}{l}\text { Bolivina aff. B. spissa Cushman } \\
\text { Cassidulina californica Cushman and } \mathrm{H} \text { ughes }\end{array}$ & $\begin{array}{l}\mathbf{r} \\
\mathbf{c}\end{array}$ & $\mathbf{a}$ & & & & & & c & & & & & \\
\hline $\begin{array}{l}\text { Cassidulina callornica Cushman and Hughes. } \\
\text { Cassidulina corbyi Cushman and Hughes.... }\end{array}$ & $\begin{array}{l}\mathrm{c} \\
\mathrm{c}\end{array}$ & $a^{2}$ & $\begin{array}{l}\mathrm{r} \\
\mathrm{r}\end{array}$ & $\mathbf{r}$ & $\mathbf{r}$ & & & $\mathrm{c}$ & & a & c & & $\stackrel{\mathscr{E}}{\mathscr{\Phi}}$ \\
\hline Cassidulina limbata Cushman and Hug. & a & & & & & & & $r ?$ & & & & & ֻू \\
\hline Cassidulina pulchella D'Orbigny & a & $\mathbf{r}$ & & & & & & & & & & & 总 \\
\hline Cassidulina subglobosa $\mathrm{H}$. B. Brady & $\mathbf{r}$ & $--\cdot$ & & & & & & $\mathbf{r}$ & $\mathbf{r}$ & c & & & $\frac{\pi}{a}$ \\
\hline Cibicides aff. C. lobatus (D'Orbig & c & & & & & & & & & & & & 2 \\
\hline Dentalina fragment........... & $\mathbf{r}$ & - & & & & & & & & & & & 0 \\
\hline Elphidium granulosum (Galloway and $\mathrm{W}$ & $\mathbf{r}$ & & & & & & & & & & & & $\stackrel{\Xi}{\Xi}$ \\
\hline Fissurina laevigata Reuss & $\mathbf{r}$ & $\mathbf{r}$ & & & & & & & $\mathbf{r}$ & $\mathrm{r}$ & & & : \\
\hline Globigerina bulloides D'Orbigny & a & c & & & c & $\mathbf{r}$ & $\mathrm{r}$ & & & $\mathbf{r}$ & $\mathbf{r}$ & & 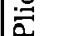 \\
\hline Globobulimina pacifica Cushman. & $r ?$ & -- & $\mathbf{r}$ & & & & & & & & & & a \\
\hline Lagena sp. & $\mathbf{r}$ & & & & & & & & & & & & 范 \\
\hline Nonion scapha (Fichtel and Moll) & $\mathbf{r}$ & & & & & & & & & & & & $\mathcal{g}$ \\
\hline Nonion steilligera (D'Orbigny) $\ldots$ & $\mathbf{r}$ & & & & & & & & & & & & 5 \\
\hline Pulvinulinella pacifica Cushman & $\mathbf{r}$ & c & c & $\mathbf{r}$ & c & & $\mathrm{r}$ & & $\mathbf{r}$ & $\mathrm{r}$ & & & है \\
\hline $\begin{array}{l}\text { Uvigerina } \mathrm{sp} \ldots \ldots \\
\text { Ostracode fragment }\end{array}$ & $\mathrm{r}$ & & & & & & & & & & & & $\dot{\sigma}$ \\
\hline $\begin{array}{l}\text { Ostracode fragment } \\
\text { Echinoid spines }\end{array}$ & $\mathbf{r}$ & -- & & & & & & & & & & & \\
\hline $\begin{array}{l}\text { Echinoid spines } \\
\text { Bolivina interjuncta Cushman }\end{array}$ & $\mathbf{r}$ & a & a & $\mathbf{a}$ & - & & & & & & & & \\
\hline Bolivina robusta H. B. Brady & & $\mathbf{a}$ & & $\mathbf{r}$ & $\bar{r}$ & & $\mathrm{r}$ & $\mathrm{r}$ & & $r$ & & & \\
\hline Bolivina seminuda Cushman & & $\mathbf{r}$ & $\ldots$ & $\mathbf{r}$ & & & & & & & & & \\
\hline Bolivina spissa Cushman & & $\mathbf{r}$ & a & & a & & & & & & & & \\
\hline & & $\mathbf{c}$ & - & & & & & & & & & & \\
\hline $\begin{array}{l}\text { Cassidulina aff. C. delicata Cushman } \\
\text { Cassidulina reflexa Galloway and Wissler... }\end{array}$ & & $\begin{array}{l}\mathbf{r} \\
\mathbf{r}\end{array}$ & $\mathbf{r}$ & $\mathbf{r}$ & & & $\mathbf{r}$ & & & & & & \\
\hline Cassidulina translucens Cushman and Hugh & & c & $\mathrm{r}$ & $\mathbf{r}$ & c & c & c & $\mathrm{r}$ & a & c & & & \\
\hline Galloway and Wissler & & c & & & & & & & & & & & \\
\hline $\begin{array}{l}\text { Frondicularia advena Cushman } \\
\text { Gaudryina arenaria Galloway and Wissle }\end{array}$ & & c & $\mathbf{r}$ & $\mathbf{r}$ & c & & & $\mathbf{r}$ & $\mathbf{r}$ & $\mathrm{r}$ & & & \\
\hline $\begin{array}{l}\text { Gaudryina arenaria Galloway and Wissle } \\
\text { Globigerina concinna Reuss }\end{array}$ & & $\mathbf{r}$ & $\mathrm{r}$ & -5 & & 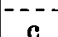 & $\Gamma$ & & & & & & \\
\hline $\begin{array}{l}\text { Globigerina concinna Reuss } \\
\text { Globigerina inflata D'Orbigny }\end{array}$ & & $\begin{array}{l}\mathbf{r} \\
\mathbf{r}\end{array}$ & $\mathbf{r}$ & a & $\mathrm{r}$ & $c$ & $\mathbf{I}$ & & & $\mathrm{c}$ & & & \\
\hline Globigerina quadrilatera Galloway and Wissler & & c & & & & $\mathbf{r}$ & $\mathbf{r}$ & $\mathbf{r}$ & & & & & \\
\hline Gyroidina soldanii D'Orbigny var. rotundimargo $R$. E. and $F$ & & & & & & & & & & & & & \\
\hline Lagenart acuticostata Reuss & & $\begin{array}{l}\mathbf{r} \\
\mathbf{r}\end{array}$ & & & & & & $I$ & & & & & $\mathscr{d}_{0}^{ \pm}$ \\
\hline Nodos & & c & c & & & & & & & $\mathbf{r}$ & & & ¿ \\
\hline Nodosaria aff. N. soluta (Reuss) & & c & $\mathbf{r}$ & $\mathbf{r}$ & $\mathrm{r}$ & & & & & & & & $\ddot{\bar{Q}}$ \\
\hline Nodosaria tosta Schwager.............. & & $\mathbf{r}$ & & & & & & & & & & & 尔 \\
\hline D'Orbigny $\ldots . . . . . . .$. & & $\mathbf{r}$ & & & & & & & & & & & $\approx$ \\
\hline Planulina orn & & $\mathbf{r}$ & $\mathrm{r}$ & & & $\mathbf{r}$ & $\mathbf{r}$ & $\mathbf{r}$ & c & c & $\mathbf{r}$ & & $\bar{\Omega}$ \\
\hline Pulvinulinella k & & $\mathrm{c}$ & $\mathbf{r}$ & & & c & & c & $\mathbf{r}$ & $\mathbf{c}$ & & & \\
\hline $\operatorname{man}_{-\ldots}$ & & a & a & a & $\mathbf{a}$ & & & & $\mathbf{r}$ & & & & \\
\hline ina Cushman var. bradyana Cushman. & & c & $\ldots$ & $\mathrm{r}$ & c & -.. & & & & $\mathrm{r}$ & & & \\
\hline Uvigerina pygmaea D'Orbigny & & $\mathrm{r}$ & & & & & & & & $\mathbf{r}$ & & & \\
\hline Cassidulina aff. C. tortuosa Cushman and Hughes... & & & $\mathbf{r}$ & & & ..- & & & & & & & \\
\hline Chilostomella & & & $\mathbf{r}$ & & & 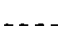 & & & & & & & \\
\hline Eponides tenera (H. B. Brady) & & & c & $\mathbf{r}$ & c & $\mathbf{r}$ & & & & $\mathbf{r}$ & & & \\
\hline Globigerina pachyderma (Ehrenberg) & & & $\mathbf{r}$ & & & & & & & & & & \\
\hline Globobulimina aff. C. pyrula (D'Orbigny) & & & $\mathbf{r}$ & ..- & -- & --- & & & & & & $\ldots$ & \\
\hline Nodogenerina sp & & & $\mathbf{r}$ & & & & & & & & & & \\
\hline Planulina sp. A & & & c & $\mathbf{r}$ & c & & & & & & & & \\
\hline Pullenia salisburyi R. E. and K. C. Stewart. & & & $\mathbf{r}$ & $\mathbf{r}$ & $\mathbf{r}$ & & & & & & & & \\
\hline Sphaeroidina bulloides D'Orbigny & & & $\mathbf{r}$ & $\mathbf{r}$ & $\mathbf{r}$ & $\mathbf{r}$ & & & & $\Gamma$ & $r$ & & \\
\hline Uvigerina sp & & & c & & & & & & & & & & \\
\hline 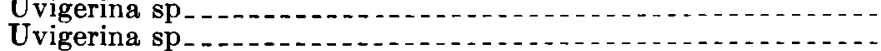 & & & $\begin{array}{l}\mathbf{r} \\
\mathbf{c}\end{array}$ & & & & & & & & & & \\
\hline
\end{tabular}

${ }^{50}$ Eldridge, G. H., and Arnold, Ralph, The Santa Clara Valley, Puente Hills, and Los Angeles oil districts, southern California: U. S. Geol. Survey Bull. 309, p. 107, 1907. ${ }^{31}$ Idem, p. 152. 
Foraminifera collected from Miocene, Pliocene, and Pleistocene formations near Santa Monica, Calif.-Continued

Bolivina aff. B. interjuncta Cushman

Bulimina affinis D'Orbigny ...

Cassidulina tortuosa Cushman and Hughes

Cassidulina aff. C. laevigata D'Orbigny

Cibicides?

Nodosaria aff. N. arundinea Schwager

Planulina aff. P. ornata (D'Orbigny)

Uvigerina urnula D'Orbigny

Uvigerina aff. U. pygmaea D'Orbigny

Valvulineria araucana (D'Orbigny)

Buliminella elegans (D'Orbigny) var.....

Eponides subtenera (Galloway and Wissler)

Uvigerina peregrina Cushman var. parvula Cushman

Bolivina aff. B. argentea Cushman

Bolivina sinuata Galloway and Wissler

Buliminella aff. B. curta Cushman var. basispinata R. E. and K. C. Stewart

Cassidulina quadrata Cushman and Hughes.

Nodogenerina $\mathrm{sp}$

Sigmolina elliptica Galloway and Wissler

Uvigerina $\mathrm{sp}$

Nodosaria sp.

Vigerina aff. U. urnula D'Orbigny

Cibicides mekannai Galloway and Wissler

Epistomina bradyi Galloway and Wissler

Nodogenerina antillea (Cushman)

Nonion pompilioides (Fichtel and Moll)

Robulus rotulatus (Lamarck)

Uvigerina sp

Bolivina sp

Bulimina inflata Seguenza.....

Bulimina aff. B. inflata Seguenza

Cibicides sp

Cibicides aff. C. haidingeri (D'Orbigny)

Gyroidina aff. G. soldanii D'Orbigny

Pullenia sphaeroides (D'Orbigny)

Radiolaria sp. a

Radiolaria sp.

Fish teeth

Bolivina sp

Clavulina sp.

Fissurina sp. parexilis Cushman and $\mathbf{K}$. C. Stewart

Bolivina advena Cushman

Bolivina aff. B. marginata Cushmant.

Bolivina sp.

Bolivina hughesi Cushman

Bolivina aff. B. plicata D'Orbigny

Buliminella curta Cushman

Eponides aff. E. broeckhiana (Karrer)

Eponides sp

Nodosaria koina
Planulina sp. b

Uvigerina $\mathrm{sp}$

Uvigerina $\mathrm{sp}$

Diatoms

Radiolaria sp. c

Radiolaria sp. d

Buliminella brevior Cushman

Bolivina aff. B. advena Cushman

Cassidulina sp.... Cushman

Pulvinulinella sp.

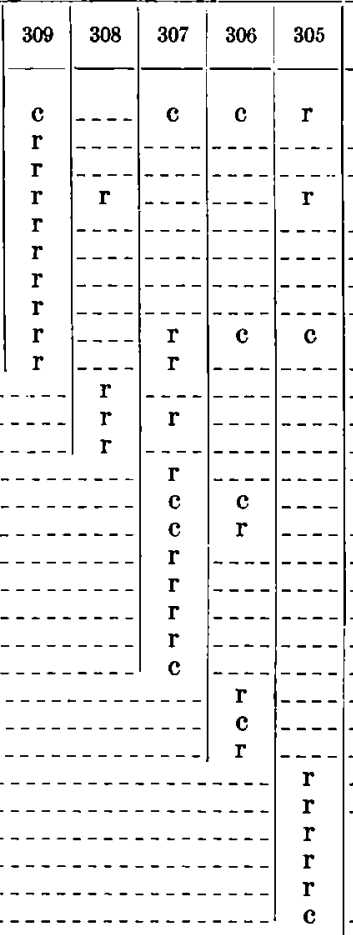

\begin{tabular}{|l|l|l|l|l}
\hline 302 & 301 & 303 & 304 & Age \\
\hline r & & & & \\
\end{tabular}

Messrs. Hughes and Goudkoff have submitted the following statement concerning the Foraminifera listed in the table:

Samples 303 and 304 are of upper Miocene age and may be tentatively correlated with the middle part of the lower member of the Modelo as exposed along the road between Garrapata Canyon and Girard, or that part of the section between localities 120 and 140. (See pl. 27, C.)
Samples 301, 302, 305, 306, and 307 are considered to be of lower Pliocene age and contain a fauna that appears to be equivalent to that found in producing wells of the Seal Beach oil field between depths of 3,000 and 4,000 feet. They also may be correlated with beds in Adams Canyon, Ventura County, that lie 12,000 to 14,000 feet stratigraphically below the so-called Saugus-Pico contact.

Samples 308, 309, and 310 are considered to be of upper Pliocene age and may be tentatively correlated with strata 


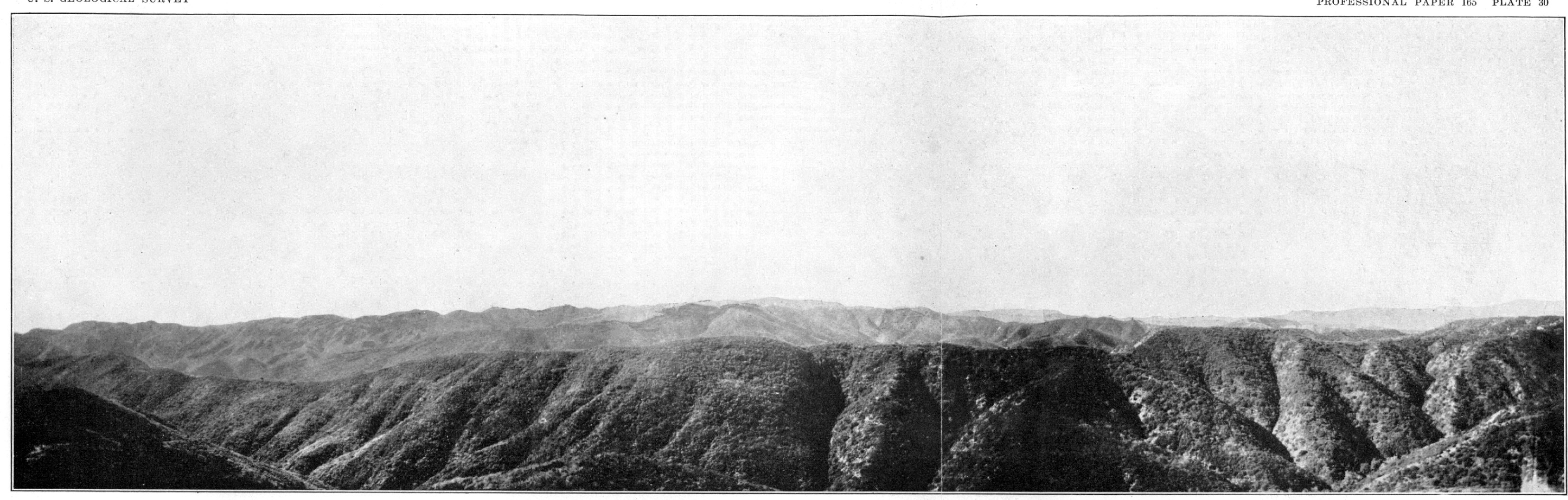

A. VIEW LOOKING WEST ALONG CREST OF SANTA MONICA MOUNTAINS, CALIF,, From POINT ON RIDGE WEST OF MANDEVILLE CANYON Shows the smooth, nearly horizontal sky line. The less distant ridge tops are remnants of an old Pleistocene erosion surface.

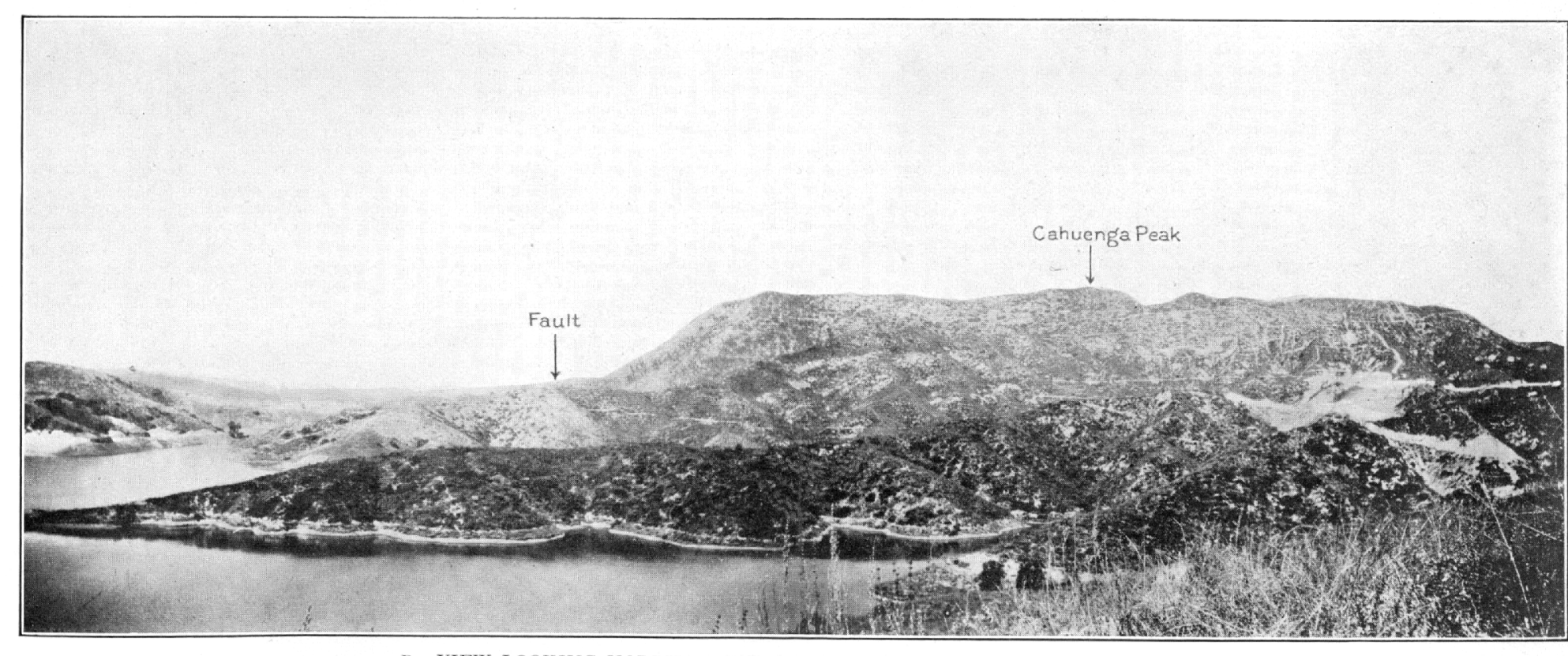

B. VIEW LOOKING NORTH-NORTHWEST ALONG CAHUENGA FAULT, CALIF.

Cahuenga Peak and the ridge east of the fault are composed of conglomerate of the Topanga formation dipping $20^{\circ}-30^{\circ} \mathrm{N}$. Along the fault the conglomerate abuts against younge

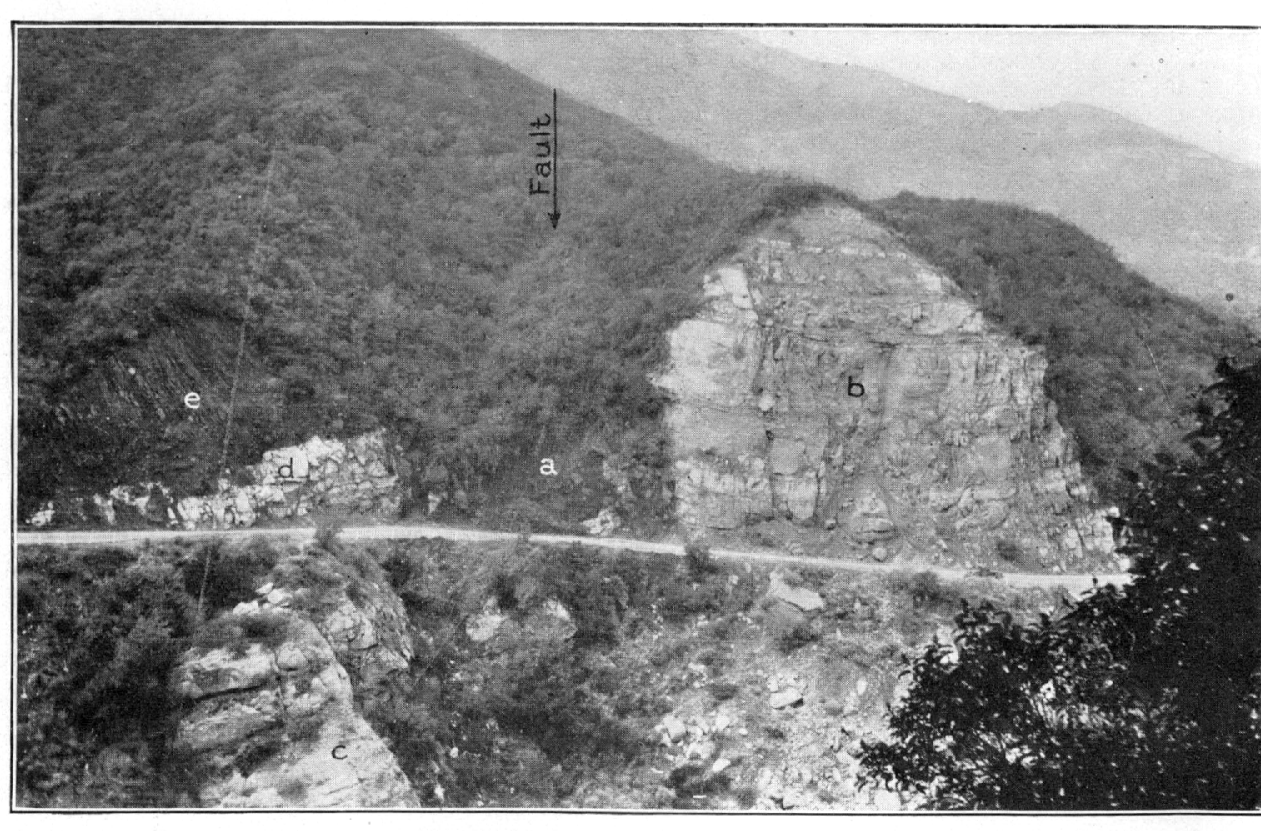

C. VIEW LOOKING WEST ACROSS TOPANGA CANYON 1 MILE BELOW TOPANGA, CALIF,

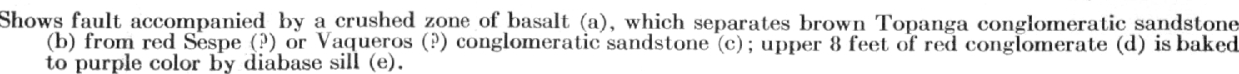





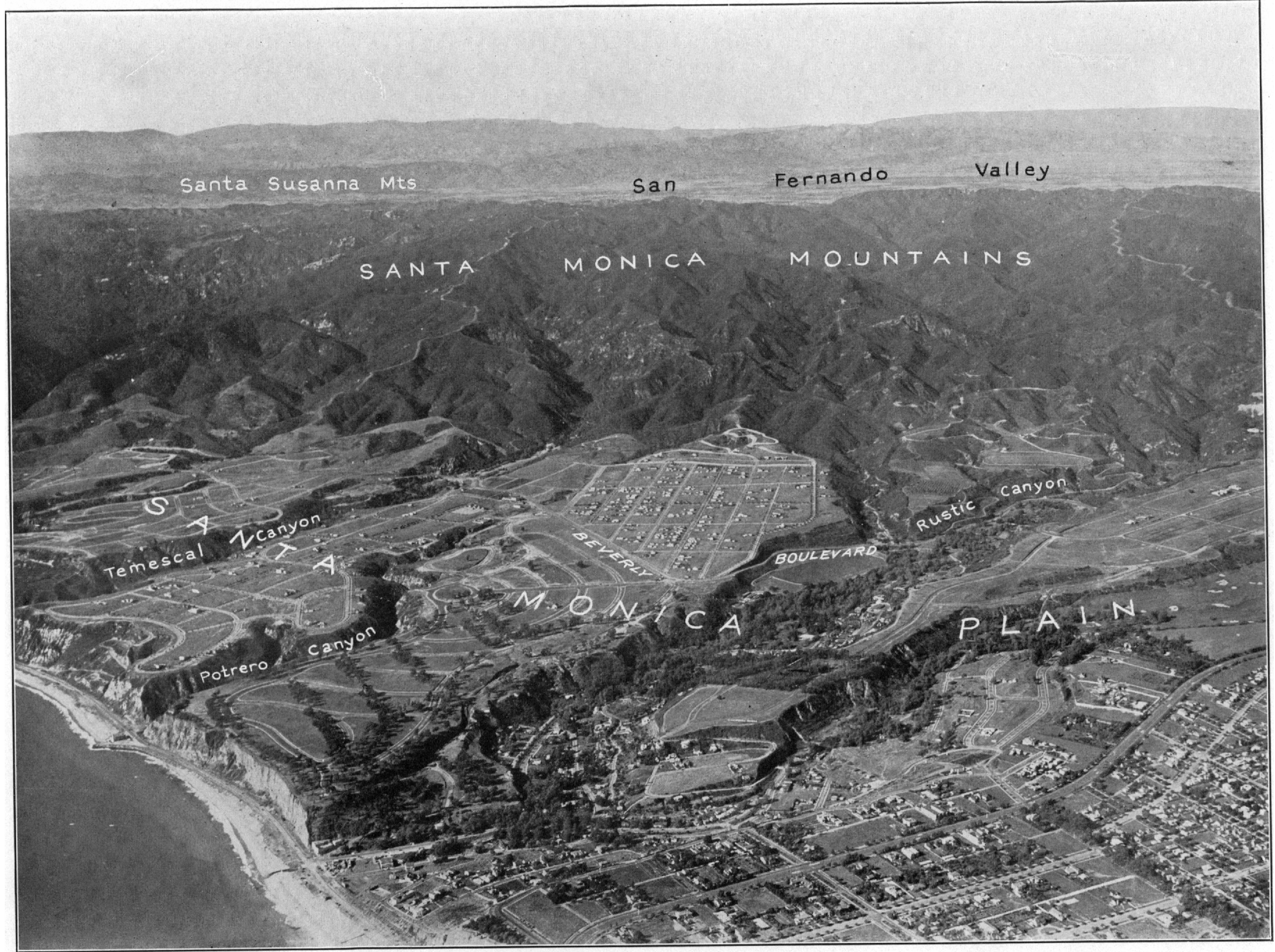

AIRPLANE VIEW TAKEN ABOVE THE CITY OF SANTA MONICA LOOKING NORTH AT SANTA MONICA MOUNTAINS, CALIF, Photograph by Spence Airplane Photos. 


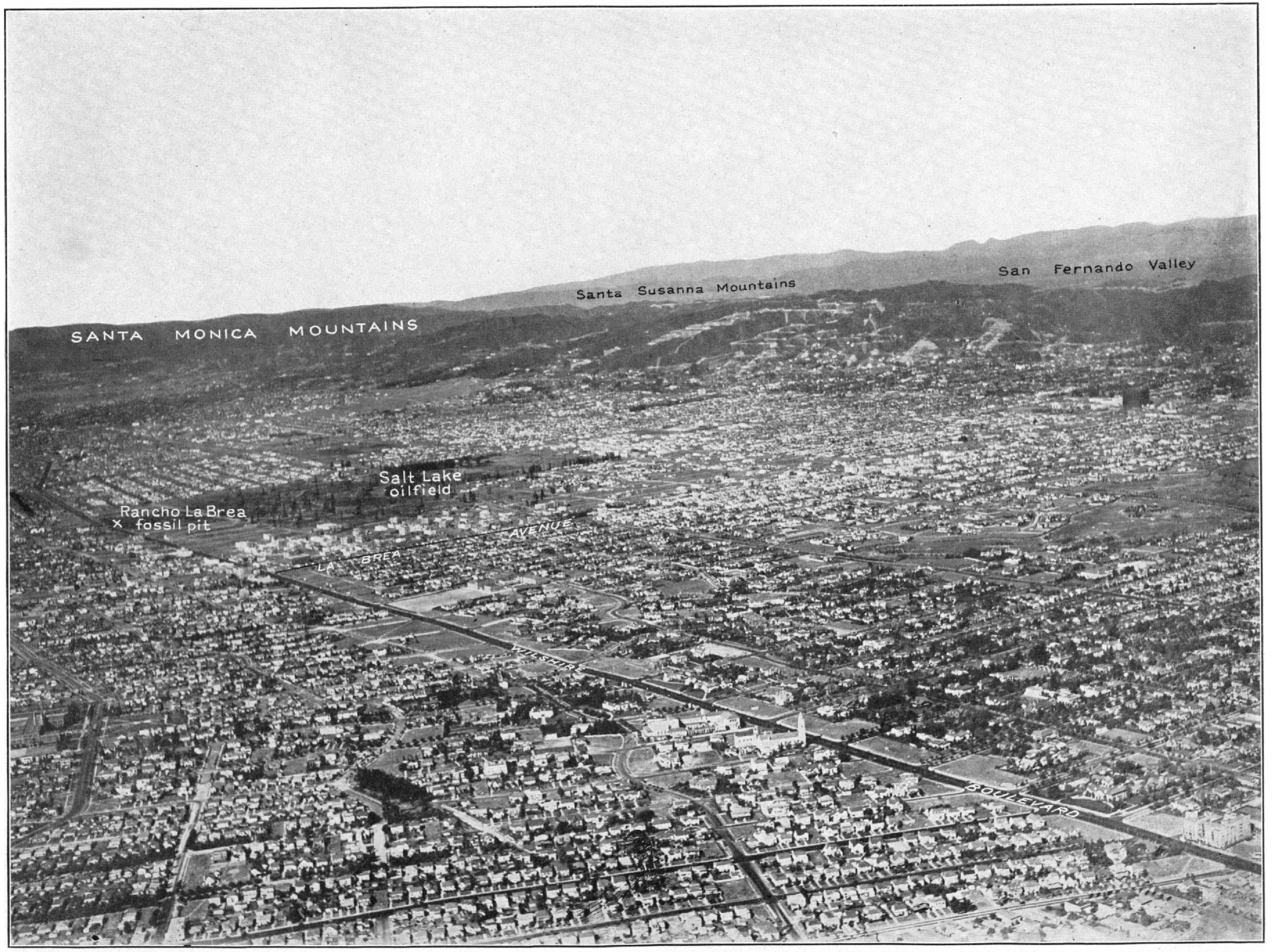

AIRPLANF VIEW LOOKING NORTHWEST OVER PART OF THE RESIDENTIAL DISTRICT OF WESTERN LOS ANGELES, CALIF,

Shows the present small producing area of the Salt Lake oil field siluated on the alluvial plain south of the Sanla Monica Mounlains. Photograph by Spence Airrlante Photos. 
penetrated by producing wells of the Seal Beach oil field between depths of about 2,000 and 3,000 feet. They are also equivalent to beds in Adams Canyon that lie 5,000 to 10,000 feet stratigraphically below the so-called Saugus-Pico contact.

Doctor Goudkoff's interpretation of the foraminiferal evidence provided by collections 311 and 312, taken in isolated areas, appears on pages 119-120.

\section{SAN DIEGO FORMATION (MIDDLE OR OPPER PHOCENE)}

The San Diego formation is exposed in the coastal belt south of the Santa Monica Mountains and is represented by a massive soft light-gray conglomeratic sandstone, which crops out in lower Temescal Canyon and is best exposed along the axis of a prominent syncline in the west wall of the canyon 300 to 500 feet north of the Coast Highway. The entire thickness of sandstone at this locality is about 50 feet, but there appears to be a distinct break about 15 feet above the base which divides it into two separate units. The lower unit appears to grade downward into Modelo shale and is therefore believed to be Miocene. The upper unit is definitely Pliocene and is correlated by its megascopic fossils with the San Diego formation. Although the exposure is in a difficult place to examine satisfactorily, there is a strong suggestion that the uppermost beds of the lower unit are truncated by its upper surface. Angular blocks of Pholas-bored limestone, absent in the lower unit and presumably derived from the underlying Miocene, are abundant just above the contact and throughout the upper unit of sandstone. This upper sandstone is rich in countless brachiopods and Pectens, which are included in a fauna that Arnold recognized as being equivalent to that found in the San Diego formation. ${ }^{53}$

W. P. Woodring has identified the following fossils collected from the San Diego formation in lower Temescal Canyon, near Santa Monica (locality 55):

Brachiopod:

Dallinella occidentalis (Dall).

Gastropod:

Opalia varicostata Stearns.

Lamellibranchs:

Ostrea vespertina Conrad.

Pecten bellus hemphilli Dall?

Pecten stearnsii Dall.

"Pecten" healeyi Arnold.

"Pecten" cerrosensis Gabb.

"Pecten" purpuratus Lamarck var.

Chlamys hastatus (Sowerby).

Chlamys opuntia (Dall).

Chlamys swiftii parmeleei (Dall).

Lucinoma annulata (Reeve)?

Miltha sp. ef. M. xantusi (Dall).

Woodring's comments are as follows:

The San Diego affinities of this small fauna were recognized by Arnold. ${ }^{54}$ The same species are found in so-called Saugus beds north of Simi Valley. ${ }^{55}$ The occurrence of these distinc-

${ }^{33}$ Arnold, Ralph, U. S. Nat. Mus. Proc., vol. 32, p. 527, 1907.

54 Arnold, Ralph, U. S. Nat. Mus. Proc., vol. 32, p. 527, 1907.

ss Woodring, W. P., California Acad. Sci. Proc., 4th ser., vol. 19, pp. 57-64, 1930. tive species so far north disposes of the idea that the warmwater San Diego fauna lived at San Diego at the same time that a cool-water fauna lived in the Los Angeles and Ventura Basins. The considerable percentage of extinct species clearly shows that this fauna is well down in the Pliocene. This is the only locality around the western border of the Los Angeles Basin where the San Diego fauna is found. It also is the only locality in southern California where fossil brachiopods are abundant. More than 200 specimens of Dallinella occidentalis from this locality show a wide range of variation, embracing forms like "Terebratalia" smithi Arnold. Many of the species recorded by Rivers ${ }^{56}$ undoubtedly were collected at this locality, but more than one horizon is represented in his Pliocene.

Possibly the locality record "Tremochal Canyon, Santa Monica, Pleistocene," given by Canu and Bassler ${ }^{57}$ for six species of Bryozoa, is an error for Temescal Canyon, but it is improbable that any but incrusting Bryozoa are to be found in the coarse sand of the San Diego formation.

\section{PLIOCENE NEAR SAWTELLE}

A small isolated exposure of late Pliocene rocks occurs on the east side of Brentwood Knoll, near the west edge of the town of Sawtelle. The rocks consist of gray clay and sandy clay and have been considerably deformed. Foraminifera from these beds are listed as collection 312 on page 117 and are discussed by Doctor Goudkoff as follows:

The microfauna found in sample 312 , though rather closely related to that discovered in the so-called Pliocene beds of Deadman Island, differs from it, first, in the abundance of Bolivinas and Uvigerinas; second, in the presence of Frondicularia advena; third, in the absence of Dentalina baggi, Elphidium (Themeon) crispum, Globorotalia campanulata, Globorotalia grandis, Polymorphina elongata, Polymorphina frondiculariformis, and some others, which seem to be definitely confined to the youngest formations of southern California like those exposed in the Lomita quarry, Deadman Island, Timms Point, and at the Santa Barbara Bathhouse Beach. On the other hand, the foraminiferal association present in sample 312 shows a great similarity to that found in a lower part of the Kalorama Canyon section of Ventura County, particularly that underlying the strata mapped by Kew as Saugus. Thus I am inclined to believe that sample 312 comes from a part of the upper Pliocene.

\section{PLIOCENE (?) IGNEOUS ROCKS}

In the coastal belt there are small areas of basalt whose age is indefinite. About 1,500 feet up from the mouth of Pulga Canyon, in the small canyon directly to the west, ${ }^{58}$ light-gray and brown shale of the Modelo formation is faulted against red sandstone and conglomerate of the Sespe (?) and Vaqueros (?) formations. Basalt has been intruded along the fault contact (see pl. 16), presumably at about the time that fault displacement occurred. As this faulting involves upper Miocene rocks, the basalt must be younger and may well be of Pliocene or post-Pliocene age.

38 Rivers, J. J., Descriptions of some undescribed fossil shells of Pleistocene and Pliocene formations of the Santa Mlonica Range: Southern California Acad. Sci. Bull., vol. 3, pp. 69-72, 1904.

si Canu, Ferdinand, and Bassler, R. S., L. S. Nat. Mus. Bull. 125, pp. 139, 170, $179,195,198,202,1923$.

${ }^{39}$ Since these observations were made exposures in this small canyon have become concealed by fill and excavation for a new Bay Club. 
UPPER PLIOCENE OR LOWER PLEISTOCENE ROCKS LOWER RUSTIC CANYON

A small isolated exposure of clay, silt, and soft sandstone of upper Pliocene or lower Pleistocene age occurs in a storm-drain ditch in the west wall of lower Rustic Canyon about half a mile from the coast. These beds have been tilted considerably and dip $12^{\circ}$ S. Megascopic fossils collected from this area (locality 311) are identified and discussed by W. P. Woodring as follows:

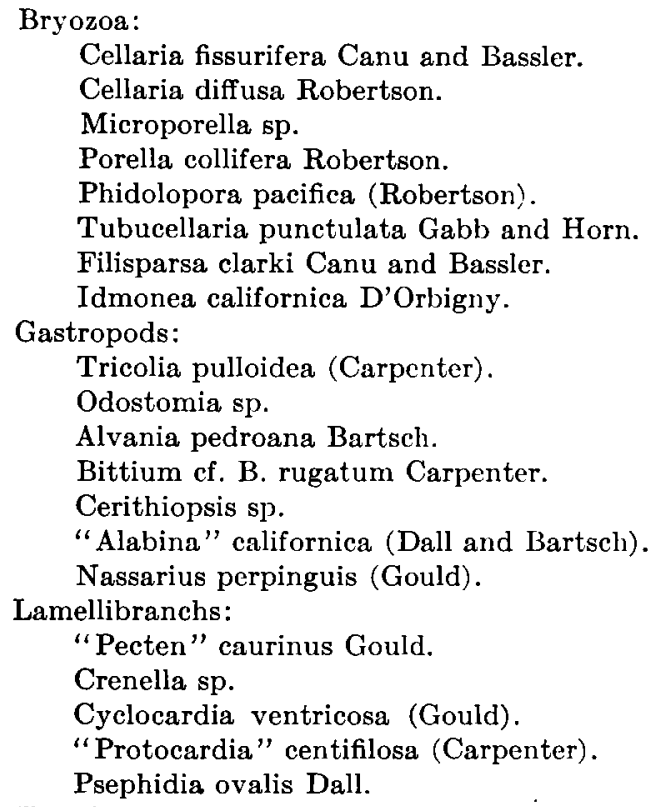

(For Foraminifera collected at this locality see p. 117.)

This collection represents the cool-water horizon of the Los Angeles Basin, found at Timms Point and formerly at Deadman Island, and probably also the cool-water zone represented in the deposits that have been called Santa Barbara beds. Bryozoa are very abundant at the locality in Rustic Canyon, as at other places where this cool-water fauna is represented. Canu and Bassler ${ }^{59}$ record 22 species of Bryozoa from Rustic Canyon, 8 species from Long Wharf Canyon (presumably Potrero Canyon), 6 species from "Tremochal" (Temescal?) Canyon, and 9 from Santa Monica without any definite locality data, making a total of $\mathbf{4 5}$ species of Bryozoa referred by them to the Pleistocene from localities near Santa Monica, none of which are recorded from more than one locality.

Doctor Goudkoff makes the following interpretation of the foraminiferal fauna found in collection 311 at this locality:

The microfauna present in sample 311 differs from that found in sample 312 in the absence of Frondicularia advena, the nearly entire absence of Bolivinas and Uvigerinas, and the presence of Nonion scapha and Elphidium (Themeon) granulosus. Such features make it possible to state, first, that sample 311 seems to be still closer to the Deadman Island beds and, second, that it falls in the part of the Kalorama section stratigraphically higher than that with which sample 312 can be correlated.

59 Canu, Ferdinand, and Bassler, R. S., U. S. Nat. Mus. Bull. 125, 1923. Four of the species (Cellaria fissurifera, Stephanosella biapteria, Phidolopora pacifica, Crisia serrata) have only the indefinite locality record "Santa Monica" in the text but in the explanationof the plates are recorded from Rustic Canyon. Porella cyclopea, listed on page 14, seems to be a nude name.
Samples 311 and 312 may be correlated with the uppermost part of the Pico formation as mapped by Kew in the Pico Canyon district.

At the mouth of Potrero Canyon about 100 feet of gently dipping bluish-gray and brown sandstone and conglomerate rests upon and is faulted against more steeply dipping Pliocene beds and contains a fairly good fauna of marine invertebrates.

The following fossils were collected from the basal conglomeratic bed of the Pleistocene section exposed at the mouth of Potrero Canyon (locality 31). This bed crops out in the bottom of the canyon about 50 feet north of the Coast Highway. The fossils have been identified by W. P. Woodring, and his discussion follows the list.

Gastropods:

Calliostoma costatum (Martyn).

Calliostoma tricolor Gabb.

Tricolia compta (Gould).

Neverita recluziana (Deshayes).

Turritella cooperi Carpenter.

Bittium sp.

Mitrella gausapata (Gould).

Mitrella carinata (Hinds).

Nassarius perpinguis (Hinds).

Nassarius cooperi (Forbes).

Olivella biplicata Sowerby.

Olivella pedroana (Conrad).

Conus californicus Hinds.

Megasurcula carpenteriana (Gabb).

Lamellibranchs:

Ostrea sp.

Monia macroschisma (Deshayes).

Thracia trapezoides Conrad?

Cyclocardia ventricosa (Gould).

Thyasira gouldii (Philippi).

Cerastoderma nuttalli (Conrad).

Venerupis staminea (Conrad).

Petricola carditoides (Conrad).

Macoma cf. M. inquinata (Deshayes).

Gari californica Conrad?

Spisula sp.

Pholadidea penita (Conrad)?

In addition to many of the species in the preceding list Arnold ${ }^{60}$ recorded the following from this locality: "Bela" sanctae-monicae (type locality), "Pisania" fortis, "Pleurotoma" perversa, and "Trophon" scalariformis. I doubt whether "Pisania" fortis is found in these beds. Aside from this record the fossils at this locality are like those at the cool-water horizon of Timms Point and Deadman Island, which lies at the top of the Pliocene or at the base of the Pleistocene, the assignment depending on where the Pliocene-Pleistocene boundary is placed. The doubtful record of Thracia trapezoides, a characteristic species of this cool-water horizon of the Los Angeles Basin, is based on an imperfect mold.

\section{UPPER PLEISTOCENE ROCKS}

Marine Pleistocene strata of slight thickness, probably of upper Pleistocene age, are exposed in Potrero Canyon. Similar deposits, presumably of about the same age, occupy two large isolated areas east of the city of Santa Monica, between Santa Monica and

\footnotetext{
${ }^{60}$ Arnold, Ralph, California Acad. Sci. Mem., vol. 3, p. 56, 1903.
} 
Venice Boulevards. The most extensive series of Pleistocene rocks in this district, however, is the continental material that forms the broad high alluvial plain along the south flank of the mountains from Beverly Hills west to Santa Ynez Canyon-a plain which is now trenched by north-south canyons to depths of as much as 300 feet. (See pl. 31.)

\section{MARINE PLEISTOCENE}

Well-sorted light-brown sand of fine to medium-fine texture occupies the high gently sloping terraces along the coast between the mouths of Topango and Santa Ynez Canyons. A small amount of this marine sand has a distinct reddish tinge, a color which is due, no doubt, to the fact that this Pleistocene material has been derived in part from the red Sespe (?) and Vaqueros (?) formations, which are exposed in this part of the coastal belt.

Farther east, between Santa Ynez and Santa Monica Canyons, Pleistocene alluvial-plain material rests directly upon sharply deformed Tertiary rocks in much of the area, but there are localities where a thin veneer of marine Pleistocene intervenes and separates these two terranes. In upper Potrero Canyon, about a quarter of a mile south of Pacific Palisades post office, 5 feet or less of fine white and brown sand rests directly upon tilted Pliocene rocks and underlies about 50 feet of coarse brown alluvial-plain detritus. This thin bed of sand contains a well-preserved marine molluscan fauna of about 125 species (locality 61). In the lower part of this canyon about 25 feet of horizontal light-gray sand and clay of probable marine origin underlies the uppermost brown alluvial-plain material, but because of its poor exposures and uncertain character it has been mapped as a part of the overlying continental deposits.

Two large areas east of Santa Monica and between Santa Monica and Venice Boulevards (see pl. 16) are occupied by soft sand, clay, gravel, and conglomerate that are considered to be of marine origin and late Pleistocene age. Like all other marine Pleistocene deposits of this district, these sediments are not of latest Pleistocene age, for in the area of the Beverly Hills oil field they pass beneath the Pleistocene alluvial material that forms the Santa Monica Plain. In the more western area, in and just east of the city of Santa Monica, fine brown thin-bedded sand that has been washed free of all clay material is the most widespread type of rock. Near the ocean this sand occupies long, narrow ridges and bluffs which parallel the shore and which presumably represent sand bars and shore-line bluffs that were developed when the ocean stood at a higher level with relation to the land. In general, the Pleistocene of both the western and eastern areas is flat-lying, although dips as steep as $5^{\circ}$ have been observed in the more eastern area south and southwest of the Beverly Hills oil field. This area lies along the northwestward-trending line of the Newport-Inglewood uplift and may have undergone a small amount of folding, in addition to simple uplift, in post-Pleistocene time.

The only fossils found in these two areas were collected from a conglomerate exposed in a cut bank on the west side of Overland Avenue at the northwestern edge of the town of Palms (locality 68, pl. 16).

Doctor Woodring has identified the following fossils in the collection made from the thin Pleistocene sand near the head of Potrero Canyon (locality 61). His comments follow the list.

Bryozoa:

Cellaria sp.

Idmonea californica D'Orbigny.

Gastropods:

Acmaea insessa (IIinds).

Acmaea? sp.

Tegula ligulata (Menke).

Tegula aureotincta (Forbes).

Calliostoma annulatum (Martyn)?

Calliostoma supragranosum Carpenter.

Margarites optabilis (Carpenter).

Astraea undosa (Wood).

Homalopoma paucicostata (Dall).

Tricolia pulloidea (Carpenter).

Tricolia variegata (Carpenter).

"Vitrinella" sp.

Turbonilla, 5 spp.

Odostomia, 4 spp

Melanella sp.

Epitonium bellastriatum (Carpenter).

Epitonium tinctum (Carpenter).

Neveritia alta ("Dall") (Arnold).

Sinum sp.

Calyptraea contorta (Carpenter).

Crepidula adunca Sowerby.

Crepidula mummaria Gould.

Crepidula lingulata Gould.

Alvania pedroana Bartsch.

Alvania? sp.

Diala? sp.

Rissoina pleistocena Bartsch.

Lacuna unifasciata Carpenter.

Turritella cooperi Carpenter.

Caecum californicum Dall.

Micranellum crebricinctum (Carpenter).

Bittium cf. B. giganteum Bartsch.

Bittium sp.

Bittium attenuatum Carpenter.

Cerithiopsis fatua Bartsch.

Cerithiopsis fossilis Bartsch.

Seila montereyensis Bartsch.

Triphora, $2 \mathrm{spp}$.

"Alabina"? sp.

Erato columbella Menke.

Bursa californica Hinds.

Acanthina paucilirata (Stearns).

"Murex" festivus Hinds.

Tritonalia poulsoni (Carpenter).

Tritonalia barbarensis (Gabb).

Boreotrophon stuarti (Smith).

Mitrella gausapata (Gould).

Amphissa versicolor Dall.

Nassarius californianus (Conrad). 
Gastropods-Continued.

Nassarius perpinguis (Hinds).

Nassarius fossatus (Gould).

Barbarofusus barbarensis (Trask).

Marginella regularis Carpenter.

Olivella biplicata Sowerby.

Olivella pedroana (Conrad).

Conus californicus Hinds.

Clathrodrillia incisa (Carpenter).

Elaeocyma hemphilli (Stearns).

Megasurcula carpenteriana (Gabb).

Mangilia ef. M. barbarensis Oldroyd.

Mangilia, 2 spp.

"Aesopus" cf. A. oldroydi Arnold.

Terebra pedroana philippiana Dall.

Acteon traskii Stearns.

Acteon punctocoelata (Carpenter).

Acteocina culcitella (Gould).

Acteocina sp.

Sulcularia sp.

Volvula cylindrica Carpenter.

Cylichna "alba (Brown)."

Williamia? sp.

Scaphopods:

Dentalium neohexagonum Sharp and Pilsbry.

Cadulus fusiformis Pilsbry and Sharp.

Lamellibranchs:

Nucula exigua Sowerby.

Saccella taphria (Dall).

Yoldia sp.

Ostrea sp.

"Pecten" latiauritus Conrad.

Monia macroschisma (Deshayes) ?

Pandora punctata Conrad.

Pseudochama exogyra (Conrad).

Lucinisca nuttallii (Conrad).

Pauvilucina tenuisculpta (Carpenter).

Erycina sp.

Rochefortia sp.

Sportella sp.

Trachycardium quadrigenarium (Conrad).

Trachycardium procerum (Sowerby).

"Cardium" elatum Sowerby.

"Transennella" tantilla (Gould).

Amiantis callosa (Conrad).

Chione undatella (Sowerby).

Chione sp.

Venerupis tenerrima (Carpenter).

Cooperella sp.

Tellina idae Dall.

Tellina buttoni Dall.

Tellina sp.

Macoma yoldiformis Deshayes.

Macoma indentata Carpenter? (more elongate than living specimens).

Donax gouldii Dall.

Solen sicarius Gould.

Ensis californicus Dall.

Siliqua lucida (Conrad).

Mactra californica Conrad.

Spisula hemphilli (Dall).

Schizothaerus nuttalli (Conrad).

Cryptomya californica (Conrad).

Corbula luteola Carpenter.

Saxicava arctica (Linné)

Zirfaea gabbi Tryon?

Chiton:

Ischnochiton conspicuus (Carpenter).
This is a distinctly warm-water fauna. Astraea undosa, Calyptraea mammillaris, Bursa californica, Acanthina paucilirata, Terebra pedroana philippiana, Acteon traskii, Trachycardium procerum, "Cardium" elatum, A miantis callosa, Chione undatella, and Spisula hemphilli are southern species, and all except Bursa californica are not found farther up the coast than San Pedro, or the northern limit of their range is even farther south. Rissoina, Erato, and Sulcularia also are southern genera. None of the species found in these beds has a distinctly northern facies, except possibly the one listed as Cylichna. "alba," though many of them now range far up the coast.

The stratigraphic position of the sands carrying these beautifully preserved shells and the warm-water aspect of the fauna indicate that they are of upper San Pedro age. The difference in facies (fine sand as contrasted with coarse gravel) is considered sufficient to account for the difference between this fauna and the fossils of the type upper San Pedro of Deadman Island. The same sand facies and the same fauna are found several miles to the southeast at University City, along the bluff overlooking the Ballona Plain. The sands here probably correspond to the sands of the Baldwin Hills section described by Tieje ${ }^{61}$ as the Palos Verdes sands.

W. P. Woodring has provided the following identifications of the small collection of fossils made on Overland Avenue near the northwest edge of the town of Palms (locality 68):

Cerithidea californica (Haldemann).

Ostrea lurida Carpenter.

Chione undatella (Sowerby).

Tellina meropsis Dall.

The warm-water facies is about the only clue to the age of these beds furnished by this small collection. They probably represent upper San Pedro time.

\section{NONMARINE PLEISTOCENE}

Nonmarine Pleistocene deposits of the high dissected alluvial plain west of Beverly Hills are well exposed in the sea cliff and canyon walls northwest of Santa Monica and in the many new cuts along streets and roads that cross this plain, particularly Beverly Boulevard. These deposits range in thickness from a few feet to at least 200 feet, are dark brown, and are composed of poorly sorted angular rock fragments as much as several feet across, which are embedded in a soft matrix of reddish-brown clay and sand. Bedding is characteristically indistinct and very irregular. Plate $29, A$, shows a view of this continental material which forms the sea cliff near the mouth of Santa Monica Canyon, and Plate 29, $B$, is a closer view that shows the poor sorting and character of bedding common to these deposits.

This nonmarine material has been deposited by streams that flowed south from the Santa Monica Mountains in Pleistocene time and dumped much of their load of sediment before reaching the ocean. Since the Pleistocene epoch marine erosion has been active along this part of the coast, and as a result the shore has been cut back to a point several miles north and northeast of its earlier position. This

61 Tieje, A. J., The Pliocene and Pleistocene history of the Baldwin Hills, Los Angeles County, Calif.: Am. Assoc. Petroleum Geologists Bull., vol, 10, No. 5, pp. 502-512, 1 ffg., 1926. 
marine planation has thus materially reduced the distance which the streams from the north traveled to reach base level, a condition which was an influential factor in forcing these streams to cut deep canyons in the Pleistocene alluvial plain. Other factors that have contributed to the trenching of this plain are discussed on page 130 .

\section{RECENT ALLUVIUM}

Recent alluvium occurs along the courses of most of the larger streams of the mountains and covers extensive lowland areas in the adjoining San Fernando Valley and Los Angeles Basin. This material is sim- ilar to the Pleistocene alluvial-plain deposits in color, texture, sorting, and bedding, and in many places the two terranes can be distinguished only by the different relations which they bear to the present system of drainage. South of the mountains they not uncommonly merge almost imperceptibly into one another.

\section{FOSSIL LOCALITIES}

The following lists give in detail the localities where fossils were obtained in this area. The localities for macroscopic fossils are also shown by corresponding numbers on the geologic map. Localities for Foraminifera and diatoms are shown on Plate 27.

2. Brown sandstone on ridge north of Mulholland Highway, at west edge of Burbank quadrangle (triangulation station 1381)

4. Platy shale near middle of Modelo formation in road cut on South Sherman Way, 200 yards south of Mulholland Way, in NW. 1/4 sec. 34, T. 1 N., R. 15 W

5. Massive sandstone ledge with basalt in $\mathrm{NW} .1 / 4 \mathrm{sec} .31, \mathrm{~T} .1 \mathrm{~N} ., \mathrm{R} .14 \mathrm{~W}$ sec. 3, T. 1 S., R. 14 W

7. Brown sandstone on top of ridge north of Mulholland Highway and west of Laurel Canyon road in center of E. $1 / 2$ sec. 31 , T. 1 N., R. 14 W

8. Brown sandstone below basalt on road leading south from Mulholland Highway along east side of ridge in north-central part of sec. 4, T. 1 S., R. $14 \mathrm{~W}$

9. Thin-bedded shale and sandstone exposed in fresh cut at rear of Riding Academy stable along west bank of the Los Angeles River, 1,000 feet south of Los Felis Boulevard - .

10. Basal light-gray conglomeratic sandstone of Modelo formation on upper road 800 feet northeast of Will Rogers's ranch house, on mesa just north of Beverly Boulevard, west of lower Rustic Canyon

11. White diatomaceous shale on minor road along north edge of hills, 2,000 feet west of South Sherman Way
solated patch of basal graywacke of Modelo formation south of Mulholland Highway and just east of head of Sepulveda Canyon

13. Sandstone on west side of canyon, 3,000 feet south of Encino Country Club, west edge

of Van Nuys quadrangle
Country Club
Conglome at top of hill at east edge of Reseda quadrangle near Encino

14. Conglomeratic sandstone at top of hill at east edge of Reseda quadrangle near Encino
Country Club

15. Basal conglomerate of Modelo formation on ridge just west of Encino Reservoir

16. Tame general locality as 18 and 19

18. Shale on Mulholland Highway $23 / 4$ miles east of west edge of Reseda quadrangle . .......

19. Same as 18

20. Sandstone on top of hill in NE. 1/4 sec. $32, \mathrm{~T} .1 \mathrm{~N}$, R. $16 \mathrm{~W}$, Reseda quadrangle

21. Top of ridge $13 / 4$ miles east and $1^{1 / 2}$ miles north from southwest corner of Reseda quad-

rangle
23. Ridge $13 / 4$ miles east and $13 / 4$ miles north from southwest corner of Reseda quadrangle 23. Boulders in creek bed $1 \frac{1}{4}$ miles north and $13 / 4$ miles east from southwest corner of Reseda

25. Massive nodular conglomeratic sandstone on top of ridge in SW. $1 / 4$ NE. $1 / 4$ sec. $5, T .1 \mathrm{~S}$., R. $16 \mathrm{~W}$

26. Shale on ridge 2 miles east and 1 mile north from southwest corner of Reseda quadrangle

27. Shale on ridge $2 \frac{1}{2}$ miles east and three-quarters of a mile north from southwest corner of Reseda quadrangle.

28. Sandstone on west side of Santa Maria Ranch road in NE $1 / 4$ sec. $32, T$. 1 N., R. 16 W.; $28 \mathrm{~A}$ is sandstone 25 feet stratigraphically above $28 \mathrm{~B}$

29. Basal conglomerate of Modelo formation just south of 1,711-foot hill on Los Angeles city boundary and south of Mulholland Highway, in southwestern part of Reseda quadrangle.........

31. Bed of lower Potrero Canyon, 50 feet north of Coast Highway . . .

32. Fossil casts in sandstone and clay shale half a mile east of Trippet ranch in northwestern part of Topanga Canyon quadrangle

33. Soft brown sandstone on side road just east of Topanga post office, Topanga Canyon quadrangle.

34. Sandstone on low ridge in fault valley half a mile northeast of Trippet ranch in northwestern part of Topanga Canyon quadrangle.
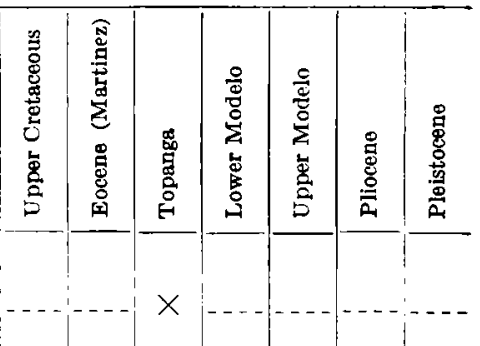

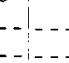

\begin{tabular}{|c|c|}
\hline & \\
\hdashline & \\
\hdashline
\end{tabular}

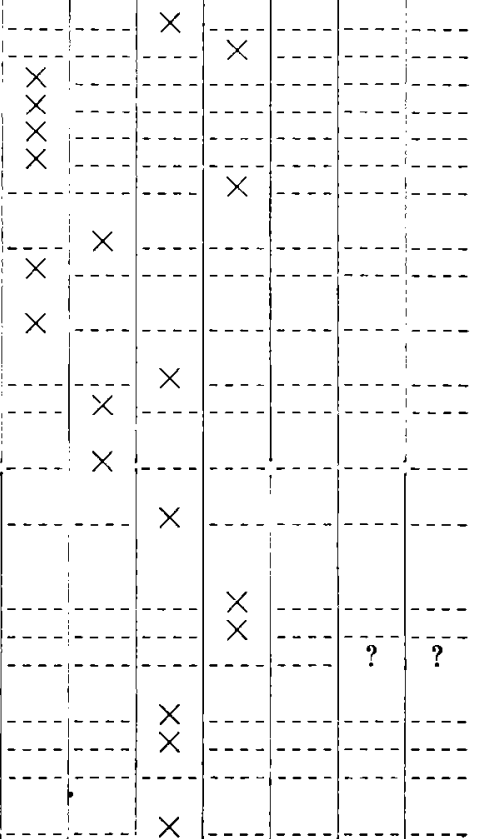


38. Conglomeratic sandstone near middle member of Topanga formation in Brown Canyon about 1,500 feet north of Beverly Glen.

41. Shale in Santa Ynez Canyon, 1,000 feet north of latitude $34^{\circ} 04^{\prime}$

42. Sandstone on top of hill just east of Santa Ynez Canyon 1 mile north of Coast Highway

43. Top of ridge east of Santa Ynez Canyon 2 miles north of Coast Highway

45. Ridge west of upper Temescal Canyon 2 miles south of north edge of Topanga Canyon quadrangle

47. Ridge just west of Temescal Canyon near north edge of Topanga Canyon quadrangle

48. Ridge just west of upper Temescal Canyon at north edge of Topanga Canyon quadrangle.

49. Road up small canyon three-quarters of a mile north of Beverly Boulevard half a mile west of Rustic Canyon

50. Top of high ridge just east of lower Sepulveda Canyon half a mile north of Beverly

51. Basal graywacke of Modelo formation on top of ridge west of Brown Canyon, near south edge of mountains

53. Sandstone on southwest side of high peak on Los Angeles city boundary 1 mile east of Cahuenga Peak and west of Griffith Park Road.

54. Massive sandstone at quarry in Santa Ynez Canyon $1 / 4$ miles north of Coast Highway

55. Massive gray sandstone in west wall of Temescal Canyon 200 yards above mouth

56. Massive conglomeratic sandstone near fault across Topanga Canyon road $2 \frac{1}{2}$ miles north of Coast Highway

57. Base of uppermost shale of lower member of Modelo formation on Mulholland Highway half a mile east of Benedict Canyon road

58. Modelo shale on top of hill just south of Mulholland Highway near head of Sepulveda Canyon, 2,000 feet east of Reseda quadrangle

59. Shale and sandstone on ridge west of Temescal Canyon 2 miles north of coast

60. Sandstone on Mulholland Highway a quarter of a mile east of Franklin Canyon

61. Bottom of un Mulland Highway a quarter of a mile east of Franklin Canyon.......

61A. Bottom of upper Potrero Canyon, 2 feet vertically below and 5 or 10 feet south of 61

62. Limestone concretion on ridge at west edge of sec. $33, \mathrm{~T}, 1 \mathrm{~N} ., \mathrm{R} .16 \mathrm{~W}$

63. Conglomeratic sandstone on ridge at west edge of sec. $33, T$. I N., R. $16-\bar{W}$

65. Base of Modelo formation on ridge top just west of lower Sepulveda Canyon

66. Approximately the same locality as $38 \ldots \ldots$.........

67. Sandy shale near tipple at limestone quarry in upper Santa Ynez Canyon.

67A. Float near west end of limestone quarry in upper Santa Ynez Canyon near $\mathbf{6 7}$ 67B. Shale underlying limestone in canyon 690 feet east of limestone quarry in upper Sarit

67C. Limestone in limestone quarry in upper Santa Ynez $\mathrm{C}$.

68. Cut bank on west side of Overland Avenue at northwest edge of town of Palms

311. Storm-drain ditch in west wall of lower Rustic Canyon half a mile from coast

\section{Foraminifera 98}

Topanga formation (middle Miocene) (see geologic map for location):

101. Sandstone and shale stringer in basalt on Cahuenga Avenue a quarter af a mile northeast of Hollywood Bowl.

102. Shale stringer in basalt on Mulholland Highway 2,000 feet east of Laurel Canyon road.

103. Thin-bedded shale and sandstone above basalt near head of Nichols Canyon.

Modelo formation (upper Miocene) (see pl. 27, $B$ and $C$, for exact locations):

104. Brown thin-bedded shale on road up hill from Coast Highway at Pacific Palisades beach stand.

105. Brown thin-bedded shale on coast at mouth of Temescal Canyon.

106. Same as 105 .

107. Hard brown shale of small fault block in Potrero Canyon.

110. White platy shale near base of Modelo formation, half a mile north of Beverly Hills Hotel. (See geologic map for location.)

111-174. Section of Modelo formation between Mohn Springs, in Garrapata Canyon, and Ventura Boulevard

175. Within 25 feet of top of exposed upper member of Modelo formation at north edge of mountains just west of South Sherman Way.

303-304. Potrero Canyon, half to three-quarters of a mile west of lower Santa Monica Canyon.

Pliocene (see pl. 27, $B$, for exact locations)

301-302, 305-310. Potrero Canyon, half to three-quarters of a mile west of lower Santa Monica Canyon.

312. From road cut in east side of Brentwood Knoll in west edge of Sawtelle just north of Wilshire Boulevard.

Upper Pliocene or lower Pleistocene:

311. Storm-drain ditch in west wall of lower Rustic Canyon half a mile from coast.

62 Although these samples were collected principally for information regarding their contained Foraminifera, the presence of Radiolaria, diatoms, and other organic remains, where noted, is mentioned in the tables within the text. 


\section{STRUCTURE}

The eastern part of the Santa Monica Mountains, east of Topanga Canyon, is a large anticline that has experienced several stages of growth and deformation. The anticlinal structure is still clearly obvious in the central part of the area, but in the eastern and western parts the original fold has been so intricately deformed by block faulting and igneous intrusion that much of the fold is either difficult to recognize as such, or is down-faulted and entirely concealed beneath alluvium. Pre-Modelo diastrophism produced an anticline which, to judge from the present westward plunge, was complete in the district east of Topanga Canyon, although similar major uplifts of this age probably occurred farther west; post-Modelo diastrophism, however, caused an anticlinal uplift that apparently affected a larger area as a unit, including the district west of Topanga Canyon as well as that east of it.

In order to discuss satisfactorily the character and possible origin of the Santa Monica anticline and related structural features (see pl. 16), it appears necessary to consider each individual period of pronounced diastrophism separately and to describe as accurately as possible the structural features which have resulted from each of these periods. There appear to have been at least three such periods-the Jurassic (?) granitic intrusion, the middle Miocene (post-Topanga and pre-Modelo) disturbance, and the post-Miocene disturbance. Under the last are grouped two disturbances, one near the end of Miocene time and the other near the end of Pliocene time, both of which were probably of major importance, although the latter was almost certainly the more intense. Deformation during other periods, such as that between Martinez (lower Eocene) and Sespe (?) and Vaqueros (?) (Oligocene? and lower Miocene) time, was probably also pronounced locally, but because its effects are not well known it is mentioned only occasionally in this discussion.

\section{JURASSIC (?) GRANITIC INTRUSION}

The intrusion of molten magma, which later solidified to form granite and granodiorite, into the Santa Monica slate, presumably at about the end of Jurassic time, was the first deformation of which there is record in the eastern part of the Santa Monica Mountains. Plate 16 shows the presence of a large granite mass northeast of Beverly Hills and other smaller areas of similar rocks much farther west, all of which owe their existence solely to the mechanism of igneous intrusion. Areas of granite farther east in Griffith Park and Hollywoodland are largely if not entirely up-faulted blocks. The intrusive bodies have metamorphosed the adjoining slate into phyllite and mica schist and have developed the spotted slate described on page 89 .
The two major exposed intrusive bodies lie within an extensive area of Triassic (?) slate that has been folded into a broad anticline. They are separated by several miles of this anticlinal slate, but the known distribution of spotted slate, as shown on the geologic map and described on page 89 , indicates that similar bodies of intrusive granite are close to the surface in intermediate areas along or slightly north of the anticlinal axis. It is considered probable, therefore, that the two major exposed bodies of intrusive granite represent merely high and relatively small portions of a much larger mass which underlies much of the area along or adjoining the axis of the Santa Monica anticline. Structure sections $\mathrm{D}-\mathrm{D}^{\prime}, \mathrm{E}-\mathrm{E}^{\prime}$, and $\mathrm{F}-\mathrm{F}^{\prime}$ (pl. 17) illustrate the breadth of this fold, which plunges rapidly westward, in general away from the largest exposed granite mass. The character of this anticline and the incompetency of the Santa Monica slate to transmit horizontal stresses adequate for its development force the conclusion that the Santa Monica anticline has resulted from vertical uplift.

Although a minor amount of anticlinal warping may have resulted directly from the Jurassic (?) intrusion, inspection of the structure sections reveals the fact that the Topanga formation has been folded nearly as much as the Santa Monica slate, and that the major development of the Santa Monica anticline must therefore have occurred in post-Topanga (post-middle Miocene) time. If the original granitic intrusion occurred in or near Jurassic time, which seems likely, it is certain that the granite and surrounding slate were uplifted at a much later time, either by renewed deep-seated igneous activity or by vertically acting forces of different origin.

\section{POST-TOPANGA AND PRE-MODELO DEFORMATION}

One of the chief periods of deformation in the Santa Monica Mountain region occurred after the middle of the Miocene epoch, between Topanga time and Modelo time. This disturbance resulted in pronounced anticlinal folding of the Topanga and all older formations, large-scale faulting in many parts of the fold, and intrusions of basalt many of which followed lines of faulting (see pl. 30, $C$ ) and probably were genetically related to all other types of deformation during this revolutionary period. The geologic map shows the marked discordance in the attitude of the Topanga and Modelo formations in different parts of the district (see also pl. 22, $B$ ) and clearly illustrates the fact that the Topanga underwent as much anticlinal folding and probably more faulting and basalt intrusion in some areas during the pre-Modelo disturbance than in subsequent deformative periods. Evidence for this is to be found in the general vicinity of Beverly Glen and the head of Benedict Canyon near the Encino Reservoir, and in the Garrapata Canyon 
area near Mohn Springs. (See geologic map and structure sections.)

Just how much of the faulting in the western part of this district took place during middle Miocene time is uncertain. The Santa Ynez Canyon and Topanga faults are believed to have been developed at this time, and it may be that most of the other faults in this and other more eastern parts of the area were formed in the middle Miocene, prior to the Modelo epoch. Many of them have certainly experienced more recent movements, but these may have occurred along preexisting fractures of middle Miocene age. If the greater part of the movement along the Santa Ynez Canyon fault took place in middle Miocene time, which seems probable, it may be that the uplift of the block on the east was in response to pronounced anticlinal bulging in the slate and granite area still farther east. The same reasoning appears to apply even better to the Temescal fault, for the relation of this arcuate fault to the major anticlinal uplift in the slate suggests that it resulted from a concentration of vertically acting forces in the core of the range to the east. However, if the rocks mapped as Topanga (?) east of this fault near the south edge of the mountains (see pl. 16) are of Miocene age, which seems probable, then movement along the Temescal fault has not been so simple. In post-Cretaceous and pre-Topanga time, presumably during the period of deformation between Martinez and Sespe (?) or Vaqueros (?) time, there appears to have been relatively large-scale uplift of the eastern block of slate; but in post-Topanga time it seems that this block, near the southern edge of the mountains at least, subsided several thousand feet.

The Hollywood fault and the arcuate fault just west of Laurel Canyon appear to be high-angle faults and to have resulted from uplift of the large body of granite, possibly at intermittent periods throughout late Tertiary time. They may, however, have developed in post-Pliocene time: there is physiographic evidence to suggest that the last movement occurred in the Pleistocene. Little can be said regarding the age of the Cahuenga fault and associated faults of the Griffith Park-Hollywood area except that all are younger than the Topanga and the more eastern ones near Los Felis Boulevard are of post-Modelo age.

The Benedict Canyon fault that cuts diagonally across the Santa Monica Mountains northwest of Beverly Hills is unique in character to judge from the effects that apparently have resulted from displacement along it. This fault trends in a northeasterly direction and appears to be a vertical shear zone along which the displacement has been at least partly horizontal and of considerable magnitude. This fault seems to be offset by a cross fault east of Benedict Canyon. Although it is shown on Plate 16 as dying out near the Mulholland Highway, before it reaches the Topanga-Modelo contact, it may continue con- siderably farther but in a more easterly direction and more nearly parallel to the strike of the rocks. Movement along this fault zone appears to have resulted in a horizontal offset of several stratigraphic units for a distance of approximately $1 \frac{1}{2}$ miles. The axis of the Santa Monica anticline also appears to be offset, although the axis of this fold east of the fault is not very evident. This offset of the anticlinal axis indicated on the geologic map is of smaller magnitude than that of the several stratigraphic units, an apparent. discrepancy which may be explained if it is assumed that considerable horizontal displacement occurred along this fault zone prior to the development of a pronounced anticlinal axis. The time at which this fault originated is uncertain. Large-scale displacement occurred in post-Topanga time, possibly before the Modelo was deposited, although certainly considerable displacement has occurred in post-Modelo time.

\section{POST-MIOCENE DEFORMATION}

Because there is little evidence in this area as to the effect of the disturbance at the end of the Miocene epoch, it is here described with post-Pliocene and post-Pleistocene disturbances under a single heading.

It seems probable that the Modelo (upper Miocene) formation was deposited over most, if not all, of the area covered by this report. As a result of postMiocene uplift in the central part of the range the Modelo was folded to form an integral part of the Santa Monica anticline and has later been eroded from much of the crest and flanks of this large fold. Structure section $\mathrm{E}-\mathrm{E}^{\prime}$ best illustrates the breadth of the anticline produced by post-Modelo folding and suggests that this last period of folding resulted merely from a rejuvenation of the vertically acting forces that had earlier produced the Santa Monica anticline. That horizontal stresses also have been active locally is evident from the apparent horizontal displacement of the Modelo along the Benedict Canyon fault.

This folding was accompanied by considerable faulting in different parts of the area, but particularly along the south flank of the mountains. The Santa Monica slate near the southern base of the range northwest of Beverly Hills is intricately distorted and appears to have undergone large-scale deformation to a much greater degree than the overlying Modelo formation, although the slate in most other areas is characterized by simple structure. The Modelo here is broken by numerous short faults, which strike approximately parallel to the base of the mountains and most of which have displacements of not more than a few hundred feet and commonly considerably less. It seems probable that these small faults have resulted from post-Miocene movement along an older buried fault which parallels the southern base of the range and, in the area west of Beverly Hills, forms a westward extension of the Hollywood fault. 
The coastal area northwest of the city of Santa Monica is one of complex structural conditions and is composed of a series of small fault blocks, now largely concealed beneath Pleistocene alluvium. The faulting involved rocks of all ages from Cretaceous to Pliocene, and it appears that this belt is an integral part of the fault zone which parallels the southern base of the range and which is the result, in part at least, of deformation after Pliocene time.

The first movement along the fault which cuts across the mouth of Potrero Canyon occurred after the marine upper Pliocene or lower Pleistocene beds at the mouth of the canyon were laid down but before the overlying uppermost Pleistocene alluvial-fan material was deposited. There is a suggestion in poor exposures in the east wall of the canyon that subsequent movement has displaced the late Pleistocene alluvial-fan deposits about 25 feet. The strike of this fault is in perfect alinement with a pronounced terrace in the surface of the late Pleistocene alluvial plain east of Potrero Canyon, a terrace which may be traced eastward to Santa Monica Canyon. This fault is well exposed, is vertical, has a strike of N. $75^{\circ}-80^{\circ} \mathrm{E}$., and has a total vertical displacement of about 150 feet. The north block has been lifted, relatively, and may have undergone considerable horizontal movement. A minor northward-dipping thrust fault occurs south of the vertical fault.

\section{CHARACTER OF FAULTS}

Some of the faults in the Cretaceous and Eocene rocks of Topanga Canyon dip north at angles as low as $40^{\circ}$; whether they are normal or thrust faults is not determinable from present knowledge of the stratigraphic sequence of the strata involved or from any exposed characteristics of the faults themselves. The northeasterly fault that cuts across the Mulholland Highway near San Vicente Mountain and terminates the Modelo formation against the Santa Monica slate is a normal fault which, in present exposures, dips $40^{\circ}$ $50^{\circ} \mathrm{SE}$. With these exceptions all faults shown on the geologic map appear to be of the high-angle type and probably either are normal faults or represent vertical or nearly vertical shear planes. It seems possible that some of the smaller faults in the coastal belt northwest of the city of Santa Monica have re$4176^{\circ}-31-4$ sulted from secondary horizontal stresses developed along the fractured zone between two or more major vertically moving fault blocks. Horizontal slickensides along the planes of minor faults in other highly disturbed parts of the area indicate that minor horizontal displacements may have accompanied other major high-angle fault movements.

\section{SUMMARY OF STRUCTURE}

By way of summary it may be said that forces of uplift recurrently active in the eastern part of the Santa Monica Mountains from the Jurassic period to the present have resulted in a pronounced, somewhat asymmetrical anticline. During the first periods of deformation, from Jurassic to late middle Miocene time, uplift was concentrated in the central graniteslate area and produced a fold that plunged rapidly to the west and, to judge from the curving strike of the lower Topanga beds just west of Cahuenga Avenue, also plunged to the east. The middle Miocene uplift of the central area appears to have produced several and possibly many major high-angle tension faults along the borders of the active area. Examples are the Santr Ynez Canyon fault, the Topanga fault, and possibly also the Temescal fault and a major fault zone along the southern base of the mountains of which the Hollywood fault is a part. Some of these faults were accompanied by intrusions of basalt, a type of igneous. activity which may have played an effective part in developing Miocene forces of vertical uplift. PostMiocene deformation, including the disturbance near the end of Miocene time, one near the end of the Pliocene time, and another near the end of the Pleistocene, increased the structural relief of the Santa Monica anticline and produced many faults in upper Miocene, Pliocene, or Pleistocene strata in all parts of the area, some of which appear to have resulted from renewed movements along older buried faults.

In consequence of these recurrent periods of deformation the Santa Monica anticline is no longer a simple fold. Much of it has been disrupted by faults and basalt intrusions, and the southeastern limb of the fold is lost from view, having been dropped, relatively, along the Hollywood fault and subsequently covered with alluvium. 


\section{GEOLOGIC HISTORY}

The salient events of the geologic history are set forth in the following table:

Summary of geologic history of the eastern part of the Santa Monica Mountains during Mesozoic and Tertiary time

\begin{tabular}{|c|c|c|c|c|}
\hline Sedimentation & Uplift, folding, faulting & $\begin{array}{l}\text { Igneous } \\
\text { activity }\end{array}$ & Result & Known area affected \\
\hline \multirow[t]{2}{*}{ Triassic (?). } & & & $\begin{array}{l}5,000-7,000 \text { feet of dark argillaceous deposits, } \\
\text { now the Santa Monica slate. }\end{array}$ & Whole area. \\
\hline & Jurassic (?). & Yes. & $\begin{array}{l}\text { Batholithic intrusion; granitic rocks; metamor- } \\
\text { phism of Triassic (?) deposits to slate, phyllite, } \\
\text { and schist; original anticlinal bulging of in- } \\
\text { truded slate probably occurred. }\end{array}$ & Central part. \\
\hline \multirow[t]{2}{*}{$\begin{array}{l}\text { Upper Cretaceous and } \\
\text { early Eocene (Chico } \\
\text { and Martinez). }\end{array}$} & & & $\begin{array}{l}8,000+\text { feet of mostly marine Chico and Mar- } \\
\text { tinez conglomerate, sandstone, shale, and } \\
\text { limestone; contains small intrusions of tra- } \\
\text { chyte of uncertain age. }\end{array}$ & Western part. \\
\hline & Post-early Eocene. & & $\begin{array}{l}\text { Unconformity with angular discordance and } \\
\text { omission of middle and late Eocene and prob- } \\
\text { ably most of Oligocene strata. }\end{array}$ & Western part. \\
\hline \multirow[t]{2}{*}{$\begin{array}{l}\text { Oligocene (?) and early } \\
\text { Miocene (Sespe?, Va- } \\
\text { queros?, Topanga). }\end{array}$} & $\begin{array}{l}\text { Gentle uplift locally } \\
\text { in early Topanga } \\
\text { time. }\end{array}$ & Yes. & $\begin{array}{l}4,500-7,500 \text { feet of conglomerate, sandstone, and } \\
\text { shale; extrusion and intrusion (?) of basaltic } \\
\text { material accompanied by uplift and erosion of } \\
\text { areas of igneous activity in eastern part of this } \\
\text { district. }\end{array}$ & $\begin{array}{l}\text { Whole area except for } \\
\text { Sespe (?). }\end{array}$ \\
\hline & $\begin{array}{l}\text { Late middle Mio- } \\
\text { cene. }\end{array}$ & Yes. & $\begin{array}{l}\text { Pronounced anticlinal folding accompanied by } \\
\text { major normal faulting and basalt intrusions. } \\
\text { This and subsequent erosion has resulted in } \\
\text { a major unconformity of this district. }\end{array}$ & $\begin{array}{l}\text { Eastern and western } \\
\text { parts. }\end{array}$ \\
\hline \multirow[t]{2}{*}{ Late Miocene (Modelo). } & & Yes. & $\begin{array}{l}4,500 \text { feet of conformable foraminiferal and dia- } \\
\text { tomaceous shale and sandstone (Modelo for- } \\
\text { mation) with thin beds of bentonite and acidic } \\
\text { volcanic ash throughout. }\end{array}$ & Most of area. \\
\hline & End of Miocene. & & $\begin{array}{l}\text { Importance uncertain because of meager distri- } \\
\text { bution of Pliocene rocks. Local unconformity } \\
\text { occurs in coastal belt northwest of Santa } \\
\text { Monica. }\end{array}$ & Coastal area + \\
\hline \multirow[t]{2}{*}{ Pliocene. } & & Yes. ${ }^{n}$ & $1,000+$ feet of marine clay and sandstone. & $\begin{array}{l}\text { Santa Monica Plain; } \\
\text { possibly all of } \\
\text { mountains. }\end{array}$ \\
\hline & Near end of Pliocene. & (?) & $\begin{array}{l}\text { Pronounced folding and faulting in coastal belt } \\
\text { and probably one of the two chief stages in the } \\
\text { uplift and deformation of the Santa Monica } \\
\text { anticline; possibly accompanied by minor } \\
\text { intrusions of basalt. }\end{array}$ & \\
\hline \multirow[t]{2}{*}{$\begin{array}{l}\text { Late Pliocene or early } \\
\text { Pleistocene. }\end{array}$} & & & $\begin{array}{l}100+\text { feet of fossiliferous marine conglomerate, } \\
\text { sandstone, and sandy clay. }\end{array}$ & $\begin{array}{l}\text { Coastal area near } \\
\text { mouth of Potrero } \\
\text { Canyon. }\end{array}$ \\
\hline & $\begin{array}{l}\text { Near end of Pliocene } \\
\text { or middle of Pleis- } \\
\text { tocene. }\end{array}$ & & $\begin{array}{l}\text { Probable minor uplift of Santa Monica Moun- } \\
\text { tains and Plain with faulting, as at mouth of } \\
\text { Potrero Canyon. }\end{array}$ & $\begin{array}{l}\text { Coastal area near } \\
\text { mouth of Potrero } \\
\text { Canyon. }\end{array}$ \\
\hline \multirow[t]{2}{*}{$\begin{array}{l}\text { Late Pleistocene (upper } \\
\text { San Pedro). }\end{array}$} & & & $\begin{array}{l}5+\text { feet of marine soft white sand in coastal area } \\
\text { near Potrero Canyon. }\end{array}$ & $\begin{array}{l}\text { Coastal area, Potrero } \\
\text { Canyon. }\end{array}$ \\
\hline & $\begin{array}{l}\text { Uplift, late Pleisto- } \\
\text { cene. }\end{array}$ & & $\begin{array}{l}\text { Probable minor uplift of Santa Monica Moun- } \\
\text { tains and Plain. Erosion and local removal } \\
\text { of all of late Pleistocene marine deposits. } \\
\text { Dissection of mature topography of moun- } \\
\text { tains. }\end{array}$ & $\begin{array}{l}\text { Coastal area, Potrero } \\
\text { Canyon. }\end{array}$ \\
\hline \multirow[t]{2}{*}{ Late Pleistocene. } & & & $200 \pm$ feet of alluvial-fan material. & Santa Monica Plain. \\
\hline & $\begin{array}{l}\text { Near end of Pleisto- } \\
\text { cene. }\end{array}$ & & $\begin{array}{l}\text { Uplift with probable minor faulting. Dissection } \\
\text { of Santa Monica Mountains and Plain. }\end{array}$ & $\begin{array}{l}\text { Santa Monica Moun- } \\
\text { tains and Plain. }\end{array}$ \\
\hline
\end{tabular}

a No definite proof of igneous activity during Pliocene time was found in this area, but beds of bentonite occur in the lower Pliocene of the Venice oil fleld, and thin layers of volcanic ash are present in these beds at Malaga Cove, 15 miles south of this area. 


\section{PHYSIOGRAPHY}

Geologic processes active during the Quaternary period have produced some remarkable topographic forms in the eastern part of the Santa Monica Mountains and in the adjoining lowland to the south. Although no exhaustive study of the physiography of this area has been made, the following brief consideration of the origin of some of the most conspicuous of these features may serve to evaluate, in a general way, the relative importance of the various processes in the development of the present landscape.

\section{SANTA MONICA MOUNTAINS}

The Santa Monica Mountains constitute one of the features of topographic relief in southern California. Several lines of evidence, but particularly the occurrence of elephant remains in Pleistocene rocks on some of the Santa Barbara Islands, lead to the belief that these mountainous islands were connected to the mainland and formed a westward extension of the Santa Monica Mountains during comparatively late geologic time. These islands, arranged in an eastwest chain, are now separated by deep submarine troughs, and this arrangement of islands and troughs is characteristic of the topographic form of the sea floor over an extensive area to the south, ${ }^{63}$ an area which forms an unusually broad continental shelf off the west coast of the Los Angeles Basin. A study of the form and arrangement of relief on this offshore belt has led to the belief that this portion of the continental shelf, including what was once a part of the Santa Monica Mountains, has obtained much of its present form through fault displacement of a series of comparatively small more or less rectangular blocks, the up and down movements of which have resulted in a somewhat heterogeneous arrangement of islands and submarine basins and uplands. Certainly much and possibly all of this deformation by block faulting has taken place during or since Pleistocene time. These statements apply to a district outside the limits of the present investigation, a district where critical geologic data in support of these statements are largely concealed from view.

Most of the eastern part of the Santa Monica Mountains presents a remarkably subdued topographic form and, except for its contrast in altitude to the surrounding plains, can hardly be considered mountainous. Altitudes along the crest of this part of the range commonly run from 1,300 to 2,100 feet, or 800 to 1,500 feet above the adjoining plains. The crest, as shown in Plate $30, A$, is characterized by flat-topped ridges which are strikingly concordant in general altitude. These ridge tops are remnants of an earlier physiographic surface that was developed

w See Willis, Bailey, A fault map of California: Seismol. Soc. America Bull., vol. 13, No. 1, supplement, March, 1923. across folded upper Miocene rocks of the Santa Monica anticline-a surface of probable early Pleistocene age which apparently had advanced to a state of old age prior to the uplift, or series of uplifts, that initiated the present draingge system.

The position of the main drainage divide of the eastern part of the range is one of the interesting physiographic features of the district. Inspection of the topography mapped on Plate 16 shows that this divide, instead of occupying a somewhat central position within the range, lies much nearer the northern edge and holds a general east-west course. The character of the geologic structure and the distribution of various types of rock throughout the mountains preclude the possibility that these factors have been influential in determining the position of this divide; it seems that the major controlling factor lies in the difference in the altitude of the two adjoining plains and in the distances which the northward and southward draining streams must flow to reach base level-distances which, of course, are inversely proportional to the cutting power of the streams.

Although the mountains are subdued and remarkably uniform in altitude over broad areas, there are higher and more abrupt minor topographic features that can, with considerable certainty, be ascribed to faulting, which, it is believed, has taken place in comparatively late geologic time, possibly during or at the end of the Pleistocene epoch. The San Vicente Mountain area, just west of upper Sepulveda Canyon, and the wedge-shaped granite mass bounded by the arcuate fault just west of upper Laurel Canyon are features of this sort. It also seems probable to the writer that the steep granite front of the southern border of the mountains north and northwest of Hollywood has resulted from major displacement along the Hollywood fault during or since the Pleistocene, a displacement which appears to have terminated on the west at the north end of the Newport-Inglewood uplift near Beverly Hills, and to have been represented farther west not by major faulting at this time but by pronounced uplift and tilting of the old Pleistocene alluvial plain, herein called the Santa Monica Plain. (See pls. 16 and 31.) Either this is true, or else the last pronounced movement along the Hollywood fault was earlier and the post-Pleistocene uplift of the Santa-Monica Mountains, which caused the tilting of the Santa Monica Plain, terminated abruptly near Benedict Canyon and did not affect the area to the east, an alternative for which there appears to be no evidence, structurally or physiographically. Except for local faulting, there seems to be good reason to believe that the part of the Santa Monica Mountains covered by this report was uplifted as a unit near the end of the Pleistocene. It appears certain, in addition, (1) that the Santa Monica Mountain uplift definitely terminated the Newport-Inglewood uplift, 
(2) that both of these major structural features, trending nearly at right angles to one another, were uplifted during or at the end of the Pleistocene, possibly as a result of closely related deep-seated readjustments, and (3) that this last disturbance of the Santa Monica Mountains has produced different effects along the southern border of the range, east and west of the north end of the Newport-Inglewood uplift; to the east, major displacement along the Hollywood fault has occurred; but to the west, pronounced uplift and tilting of the adjoining alluvial Santa Monica Plain was the chief result.

\section{SANTA MONICA PLAIN}

The Santa Monica Plain, now deeply incised by canyons of the present drainage system, lies north of the city of Santa Monica and extends to the east and to the west along the southern base of the Santa Monica Mountains. (See pl. 31.) It is an inclined plain formed by continental aggradation during the later part of the Pleistocene epoch, and since that time it has been uplifted and is now being mutilated by the erosive work of the present streams. The major part of the plain slopes in general accordance with the normal profile of an alluvial plain, from altitudes of 400 to 600 feet at the foot of the mountains southward to altitudes of 200 to 250 feet along the wave-cut coastal bluffs northwest of Santa Monica. Near and east of Santa Monica portions of the plain merge imperceptibly into Recent alluvium at altitudes of 175 to 200 feet.

The age of the plain is definitely late Pleistocene, because the strata of which it is composed locally rest directly upon a slight thickness of horizontal fossiliferous marine upper Pleistocene deposits.

As indicated by the existence of several levels of terraces along the deep canyons north and northwest of Santa Monica, this plain probably has not attained its present altitude by a single continuous uplift. In the neighborhood of lower Santa Monica and Temescal Canyons these terraces are strikingly developed, and there appear to be as many as four below the broad surface formed by the plain itself. Some of them are only minor features locally developed; the uppermost terrace, however, 250 to 265 feet above sea level and about 50 feet below the level of the plain, is well preserved along Temescal Canyon near Beverly Boulevard, and an equally prominent terrace occurs along the east wall of Rustic Canyon at an altitude of 400 to 425 feet, about 50 feet below the surface of the plain.

It seems possible that the development of terraces and the dissection of the Santa Monica Plain by the present streams, particularly in the area north and northwest of Santa Monica, has not been brought about entirely by uplift. A considerable amount of it, in this area at least, may be due to the part played by marine planation in destroying the southern and coastal part of the plain, thus producing a northward recession of the coast line and forcing the streams from the north to intrench their channels. Northwest of Santa Monica, west of the mouth of Santa Monica Canyon, the coast is bordered by a sea cliff 175 to 200 feet high which consists entirely of alluvial material of the Santa Monica Plain. (See pls. 29, $A$, and 31.) The possibility exists, of course, that the prominence of this sea cliff is due largely to late Pleistocene displacement along an unexposed fault that may parallel this part of the coast, and that uplift may after all have been the only effective factor in producing the cliff. The fault across the mouth of Potrero Canyon has apparently undergone about 25 feet of post-Pleistocene movement. (See p. 127.)

Of the many factors other than intermittent uplift and marine planation which may give rise to the development of stream terraces, only one-changes in climatic conditions during the Pleistocene epochappears to be worthy of consideration here. Notable variations in the amount and character of the rainfall are believed to have occurred during Pleistocene time, and it is entirely possible that such variations, affecting the load and cutting power of streams, played an important part in stream-terrace development.

\section{ECONOMIC GEOLOGY PETROLEUM}

There are two producing oil fields on the plain south of the Santa Monica Mountains. ${ }^{63 a}$ These fields, the Salt Lake and Beverly Hills oil fields, are comparatively old, having been first developed in 1903 and 1908, respectively. They were among the earliest fields of the Los Angeles Basin, and although the Salt Lake oil field was one of the large producing areas of this district between 1905 and 1912, both of these fields are now relatively unimportant.

\section{SALT LAKE OIL FIELD}

The Salt Lake oil field lies on the alluvial plain about 2 miles south of the edge of the Santa Monica Mountains, in the western part of the residential district of Los Angeles. (See pl. 32.) Its discovery was due to the presence of large seeps of heavy black oil and gas on the north side of Wilshire Boulevard and south of the area which later proved productive. The asphalt around these seeps was mined in the early days for commercial use, and it is these asphalt pits that have yielded the remarkable Rancho la Brea fauna of Pleistocene vertebrates. According to some geologists these seeps mark the location at which one of the oilproducing zones of the Salt Lake field would crop out were it not for the overlying mantle of Pleistocene alluvial-plain deposits. Commercial production was

63a A third, the Venice oil feld, was discovered in November, 1929, but details regarding the geology of this field are not available for publication. 
first obtained in this field in 1903 , and the bringing in of the first well marked the beginning of a period of development that proved up the last and most westerly of a string of oil fields which trend in an east-west direction through the northern portion of Los Angeles.

\section{GEOLOGY}

The Quaternary deposits that occupy the alluvial plain bordering the Santa Monica Mountains on the south cover the surface of the Salt Lake oil field. As a result, information regarding the geology of the field can be obtained only from a study of the logs of wells. In view of the present relatively small importance of this field and its certain extinction within a few years, no detailed study has been made of the subsurface geology. The geologic description given below is a compilation from an earlier description of the field by Eldridge and Arnold ${ }^{64}$ and from an unpublished report prepared in 1917 by Joseph Jensen and made available to the writer through the courtesy of Mr. Jensen and Mr. J. A. Taff, chief geologist of the Associated Oil Co. Mr. H. J. Steiny, of the Associated Oil Co., has provided the writer with production records of the Salt Lake and Beverly Hills oil fields.

STRATIGRAPHY

According to Eldridge and Arnold, wells drilled in the Salt Lake field have revealed a stratigraphic section which consists of 50 to 100 feet of flat-lying Pleistocene clay, coarse sand, and gravel, 1,000 to 3,000 feet of folded Pliocene clayey and sandy shale of Fernando age, and an oil zone 150 to 500 feet thick, also of Fernando age, which consists of fine to coarse sand interstratified with clayey shale and "shell." Some of the sands within the oil zone appear to be lenticular, although the main oil sand, which yielded the bulk of the oil prior to 1905 , has a fairly consistent thickness of 100 to 125 feet over a large part of the field.

The Salt Lake field underwent considerable development subsequent to the study by Eldridge and Arnold. Jensen concluded in 1917 that four separate oil zones had been encountered, the upper three of which were contributing materially to the total production of the field. The stratigraphically highest zone, which he termed the upper Arcturus zone, was encountered in the western part of the field at depths ranging from 650 to 1,750 feet. This zone produced oil having a Baumé gravity of $14^{\circ}$ to $18^{\circ}$. The second zone, called the lower Arcturus zone, was found about 900 feet below the top of the upper Arcturus zone and produced oil of $17^{\circ}$ to $19^{\circ}$ Baumé. The third zone, called by Jensen the Salt Lake zone, occurs about 2,100 feet below the lower Arcturus zone and was the most prolific oil zone of the field, having yielded practically all

${ }_{64}$ Eldridge, O. H., and Arnold, Ralph, The Santa Clara Valley, Puente Hills, and Los Angeles oil districts: U. S. Geol. Survey Bull. 309, pp. 186-195, 1907. the oil produced from the Salt Lake Oil Co.'s property and the eastern half of the Arcturus Oil Co.'s property. The oil from this zone ranged from $9^{\circ}$ to $22^{\circ}$ Baumé. The deepest oil zone was practically undeveloped in 1917 , but definite evidence of its presence about 1,000 feet below the top of the Salt Lake oil zone was made available by the records of some of the deepest wells.

STRUCTURE

Arnold ${ }^{65}$ summarized his views of the general structure of the Salt Lake oil field and its relation to the near-by Los Angeles oil fields to the east as follows:

Practically all the productive oil sands of the different Los Angeles fields lie on the southern limb of a flexure, usually a more or less well-defined anticline, whose axis extends in a westerly direction to the region approximately half a mile north of Westlake Park, where it bends about $20^{\circ}$ to the north and extends to a point about three-fourths of a mile southeast of Colegrove and something over a mile northeast of the Salt Lake field. Here it appears to bend again to the north, probably trending about $\mathrm{N} .60^{\circ} \mathrm{W}$. In the Los Angeles city fields - that is, between the Catholic Cemetery and the Westlake Park region-the southern limb of the flexure dips normally at angles varying from $30^{\circ}$ to $80^{\circ}$, while to the west, along that portion having a northwesterly trend, the dips flatten to $20^{\circ}$ or $25^{\circ}$. The Salt Lake oil field is located on the northwestern flank of a minor but probably somewhat complex fold or fault, or both, developed on the comparatively low-dipping southwestern limb of the major flexure just described. $* * *$

The exact nature of the local flexure is not known, but it is probably an anticline, more or less complicated by faults near the apex. Its axis extends in a general northeast-southwest direction. The logs of certain wells located southeast of the lagoon appear to indicate the presence of a minor anticline developed just south of the main flexure and separated from it by a fault. Still other evidence suggests a local dome-shaped structure, or quaquaversal, having its summit in the region of the lagoon.

The above description of the structure of the field is in general accordance with the conclusion of Jensen, who studied the field after its almost complete development. The accompanying structure contour map (pl. 33), based on a map prepared by Jensen, indicates the presence near the intersection of Fourth Street and La Brea Avenue of a northwestward-plunging syncline, which strikes about $\mathrm{N} .60^{\circ}-70^{\circ} \mathrm{W}$. There is a strong suggestion of a southwestward-plunging anticlinal nose northeast of the syncline; southwest of the syncline and north of the brea pits and Wilshire Boulevard is a northward-dipping monocline which, in its western portion, makes a swing to the south in such a manner as to suggest that the dominant structural feature near and northwest of the brea pits is a northwestwardplunging anticlinal nose.

\section{DEVELOPMENT}

Although a few wells were drilled near the brea pits prior to 1903 , the first producing well appears to have been completed in that year, and extensive develop-

es Eldridge, G. H., and Arnold, Ralph, op. cit., pp. 193-194. 
ment continued until 1912. By 1910 a total of 120 wells, most of which were successful, had been drilled on the Salt Lake Oil Co.'s property, and by 1912, 47 wells had been drilled on the Arcturus Oil Co.'s property. These two properties yielded most of the oil produced in the Salt Lake field. Wells of the Salt Lake Oil Co. developed a single zone; those in the northeastern part of the property were 900 to 1,800 feet deep and yielded oil ranging from $9^{\circ}$ to $15^{\circ}$ Baumé, and those in the southern part of the property were 1,200 to 3,200 feet deep and produced oil of $13^{\circ}$ to $21^{\circ}$ Baumé.

Approximately 350 producing wells were drilled with cable tools over an area of about 1,000 acres. Although most of the successful wells had an initial production ranging from 350 to 500 barrels a day, the initial production of the Salt Lake well No. 61, the Arcturus No. 65, and the Arcturus No. 39 was 400,700 , and 1,200 barrels a day, respectively. The peak of production was reached in 1908, when, according to the records of the Associated Oil Co., this field produced $4,535,800$ barrels of oil from 185 wells.

The table below shows the number of producing wells and the output for several years up to the end of 1927. Prior to June 1, 1928, the Salt Lake oil field produced $40,689,848$ barrels of oil.

Production of Salt Lake oil field for certain years

\begin{tabular}{|c|c|c|c|}
\hline \multirow[b]{2}{*}{ Year } & \multirow{2}{*}{$\begin{array}{l}\text { Number of } \\
\text { producing } \\
\text { wells }\end{array}$} & \multicolumn{2}{|c|}{ Production (barrels) } \\
\hline & & Total & $\begin{array}{l}\text { A verage per } \\
\text { day per well }\end{array}$ \\
\hline $\begin{array}{l}1904 \\
1905 \\
1906 \\
1908 \\
1915 \\
1920\end{array}$ & $\begin{array}{r}5 \\
30 \\
46 \\
130 \\
185 \\
287 \\
267 \\
98\end{array}$ & $\begin{array}{r}500,000 \\
1,776,768 \\
2,465,350 \\
2,811,800 \\
4,535,800 \\
1,632,160 \\
945,637 \\
392,028\end{array}$ & $\begin{array}{r}294 \\
174 \\
158 \\
64 \\
72 \\
17 \\
10 \\
12\end{array}$ \\
\hline
\end{tabular}

During the period between 1905 and 1910 the Salt Lake oil field was one of the most productive fields of southern California. The field was discovered at a time when oil as a fuel was first being widely used. Many of the wells produced an oil of comparatively good grade, which, in a large percentage of the wells, was associated with considerable gas. Since 1908 the production has gradually declined until in 1929 less than 100 wells were producing an average of about 10 barrels a day. The decrease in production of this field has been accentuated by the fact that deeper drilling and possible extension of the field have been discouraged by the growth of the residential district of Los Angeles toward and within what was once the producing area of the field. (See pl. 32 and compare with pl. 23 of U. S. Geol. Survey Bull. 309. Also see pl. 33 and compared with pl. 16.) Only a small portion of the once extensive field was yielding oil in 1930, and it is understood that final abandonment of this field will be accomplished in the immediate future, in order to permit the continued growth of residential and business enterprises of Los Angeles.

\section{BEVERLY HILLS OIL FIELD}

The information regarding the production and subsurface geology of the Beverly Hills oil field is presented herewith through the courtesy of Messrs. J. A. Taff, Joseph Jensen, and H. J. Steiney, of the Associated Oil Co. This field like the Salt Lake oil field, is in the low-lying area south of the Santa Monica Mountains, which constitutes the northwestern border of what is commonly termed the "Los Angeles Basin." This oil field is 1 mile south of the city of Beverly Hills, about $2 \frac{1}{2}$ miles south of the southern border of the mountains, and about 3 miles west of the Salt Lake oil field.

The first producing well in this field was drilled in 1908 , and since that time the field has provided only a comparatively small part of the oil produced in California. The largest well, No. 23 on the Wolfskill lease, produced an average of 400 barrels of oil a day during 1909. The year of peak production was 1912, when 20 wells produced a total of 246,223 barrels of oil, for a daily average per well of about 35 barrels. In 192710 wells produced 78,975 barrels of oil, for a daily average per well of 23 barrels. Prior to 1928 the field had produced a total of 2,444,646 barrels of oil. Oil from the Fox Hills No. 101 (Rodeo lease) tested $20.7^{\circ}$ Baumé gravity and contained 20.6 per cent of gasoline and about 2 per cent of sulphur. Practically the entire production of this field is controlled by the Associated Oil Co.

The Beverly Hills oil field lies near the southern and eastern edges of the elevated Pleistocene alluvial surface that is herein termed the Santa Monica Plain, near the north end of the Newport-Inglewood uplift-a zone of structural deformation that crosses the Los Angeles Basin in a northwesterly direction and is represented physiographically by a discontinuous line of low hills and scarps. In general these closely associated hills and scarps are the surface expressions of anticlines and faults respectively, structural features which are commonly assumed to result from deep-seated faulting of somewhat greater magnitude. Eight producing oil fields occur at fairly regular intervals along this zone of deformation, and the Beverly Hills field is the northernmost one of the group.

According to studies made by G. D. Hanna for the Associated Oil Co., the Fox Hills No. 101 well (Rodeo lease), in the southeastern edge of the field, penetrated marine Pleistocene strata to a depth possibly as great as 900 feet, upper Pliocene from about 900 to 2,375 feet, lower Pliocene from 2,375 to 3,067 feet, strata representing the Pliocene-Miocene "transition zone" from 3,067 to 3,337 feet, and Miocene from 3,337 
to 4,970 feet. A thickness of 900 feet for the Pleistocene seems excessive and is based on a sample from this depth which contained Pleistocene Mollusca but which may represent cavings. The beds penetrated by wells of this field consist almost entirely of clay shale, sand, and conglomerate. The major part of the oil is produced from a sandy zone just above the Miocene, in what Hanna calls the Pliocene-Miocene transition zone.

Structurally the Beverly Hills oil field, according to the subsurface structure contours by Jensen (pl. 34), is a pronounced asymmetrical dome of triangular shape elongated in an east-west direction. The structural closure of the fold is probably about 500 feet. Folding has been comparatively gentle on the north flank, where dips are about $15^{\circ}$. The south flank is much more abrupt, having dips of $45^{\circ}$ or more.

This fold presumably lies just west of a northwestward-trending fault which is believed to be the extension of the major northwestward-trending fault of the Inglewood oil field, 4 miles to the southeast. The Fox Hills No. 101 (Rodeo lease), in the southeastern part of the field, is a deep well drilled to test the productivity of lower horizons of the Miocene. Between 3,600 and 4,000 feet cores that contained an abundance of oil were obtained. Laminations in the cores showed that drilling was parallel or almost parallel to the bedding of the Miocene shale between about 4,600 feet and the bottom of the hole. Such steep dips in the cores suggest that the well either is far from vertical or penetrated beds close to a fault zone.

Although the writer is not familiar with all the information provided by this deep test, the excellent oil showings reported between 3,600 and 4,000 feet indicate that additional deep tests located near the central part of the dome might have an excellent chance of obtaining oil. The Miocene Modelo formation, which this well appears to have entered at a depth of 3,337 feet, may be as much as 4,000 or 5,000 feet thick in this area, and the underlying sandstone of the Topanga formation may be as deep as 7,000 to 8,000 feet.

OIL POSSIBILITIES OF OTHER AREAS ADJOINING THE S.ANTA MONICA MOUNTAINS

None of the eastern part of the Santa Monica Mountains described in this report appears to be worthy of consideration for possible oil production. Future exploitation should be restricted to the adjoining low-lying areas south and north of the mountains.

A number of unsuccessful wells have been drilled on the plain south of the mountains between the Beverly Hills oil field and the city of Santa Monica. Several of these wells (see pl. 16), such as the Union Oil Co. Newlin No. 1, the Southland Petroleum Syndicate Garland No. 1, the Petroleum Securities Palms No. 1, and the Santa Monica-Sawtelle Oil Co. Birch No. 1, apparently were drilled to test the oil possibilities of topographically high areas, probably on the assumption that these high areas are the surface expression of anticlinal folds or up-faulted blocks. Interpretation of the structural significance of these physiographic features is difficult, and the drilling of additional wells for oil production will be hazardous. The writer offers no interpretation for these physiographic features but believes that this district west and southwest of the Beverly Hills oil field may contain areas that are capable of producing oil. ${ }^{66}$

Beneath the Santa Monica Plain northwest of Santa Monica there are several eastward-trending faults which cut Miocene, Pliocene, and Pleistocene rocks and whose effects are exposed in Potrero Canyon and other canyons farther west. (See pl.16.) In view of the fact that some of these faults have displaced beds approximately equivalent to some of the oil-producing zones of the Los Angeles Basin and that some of these beds are beneath the surface and within reach of the drill, it is possible that commercial deposits of oil have accumulated along one or more of these faults northwest of Santa Monica or along their possible eastward extensions.

There is one structural feature along the northern edge of the Santa Monica Mountains that appears to have disturbed the otherwise continuous monocline which characterizes this flank of the mountains west of Cahuenga Pass. This feature is about $1 \frac{1}{2}$ miles north and northwest of the Encino Reservoir and appears to be a curving fault which has resulted in an abruptly discordant attitude of beds in the creek bed near the Caballero Country Club and the development of a low curving ridge of upper Modelo shale in the edge of San Fernando Valley, 1 mile to the northeast. (See pl. 16.) Little is known regarding the character of this fault. There is a bare possibility that oil may have accumulated along it, although there is no evidence that the structure of associated strata is such as to form a trap favorable for oil accumulation. In view of the scarcity of structural data and the apparent absence of seepages of petroleum or petroleum residues along the outcrops of the Modelo and underlying formations, the possibility of obtaining oil along this fault is considered to be slight.

\section{LIMESTONE}

A brief description of Eocene deposits of algal limestone in this area appears on page 92 . Limestone has been quarried on a small scale in the upper part of Santa Ynez Canyon and has been used locally to surface roads. Some of these deposits, however, are of sufficient size and purity to warrant serious consideration of the use of this limestone in the manufacture of cement.

${ }_{68}$ In November, 1929, the Ohio Oil Co. completed a flowing well along the southern border of this area near Venice, good for 2,000 barrels of $24.3^{\circ}$ Baumé gravity oil. Production was obtained from a zone 6,006 to 6,199 feet deep which occurs at the base of the Modelo, directly above a basement complex of Jurassic (?) schist. 
The remarkable irregularity and discontinuous character of these algal limestone reefs are striking features for limestone deposits. The limestone ledge exposed in the quarry in the upper part of Santa Ynez Canyon is about 50 feet thick at the quarry but appears to thicken to about 100 feet as the outcrop is followed eastward. This ledge of limestone is continuous for a distance of only about 2,000 feet.

By far the largest deposit of limestone occurs about half a mile southeast of the limestone quarry. This deposit appears to form an integral part of the sedimentary deposits with which it is associated, being conformable with both underlying and overlying shale. It appears to have a maximum thickness of approximately 700 feet and lenses out entirely both to the southeast and northwest withirt 2,000 feet of its thickest portion. The Los Angeles Mountain Park Association has made a study of the advisability of mining this algal limestone for the manufacture of cement. Its present plans include the erection of a quarry and crushing plant near the west end of the deposit. The limestone would be quarried, ground fine enough to pass through a 200-mesh screen, and mixed with water so that the resulting fluid would have about the consistency of the rotary mud used in the drilling of oil wells. This fluid would then be transported by gravity through a 10 or 12 inch pipe line extending from the crushing plant for a distance of $4 \frac{1}{2}$ miles down Santa Ynez Canyon to an anchor buoy in the ocean, whence it would be transported by ship to a cement plant to be erected at San Pedro Harbor. It has been estimated that this deposit contains approximately $20,000,000$ tons of limestone above the level of the bottom of the canyon in which the quarry and crushing plant may be located. ${ }^{67}$ The limestone is associated with a

${ }^{67}$ The writer is indebted to Mr. S. L. Gillan for general information as to the volume of limestone in this deposit. shale of very good grade, some of which is itself highly calcareous and contains scattered nodules of algal limestone. The following chemical analyses were made by the Raymond G. Osborne Laboratory, of Los Angeles, and are inserted here through the courtesy of Mr. J. H. Gilliland, of the Los Angeles Mountain Park Association. The limestone analyzed represented a composite sample of 96 feet of limestone exposed in a shaft made in the lower part of the deposit.

Analyses of cement materials in Santa Ynez Canyon

\begin{tabular}{|c|c|c|c|}
\hline & Limestone & Shale & Raw mix a \\
\hline $\begin{array}{l}\text { Silica } \\
\text { Alumina } \\
\text { Iron oxide } \\
\text { Lime } \\
\text { Magnesia } \\
\text { Loss on ignition } \\
\text { Sulphur trioxide }\end{array}$ & $\begin{array}{r}3.56 \\
.94 \\
1.86 \\
50.66 \\
2.13 \\
40.55 \\
\text { Trace. }\end{array}$ & $\begin{aligned} \text { 59. } 26 \\
\text { 15. } 80 \\
\text { 7. } 54 \\
\text { 4. } 10 \\
\text { 3. } 62 \\
\text { 6. } 58 \\
1.35\end{aligned}$ & $\begin{array}{r}\text { 13. } 86 \\
\text { 3. } 69 \\
\text { 2. } 91 \\
\text { 42. } 05 \\
\text { 2. } 41 \\
\text { 34. } 26 \\
.25\end{array}$ \\
\hline
\end{tabular}

- Calculated, using 81 per cent limestone and 19 per cent shale, a mixture suggested for Portland cement.

\section{SANDSTONE AND BASALT}

Sandstone from some parts of the Chico formation of the Topanga Canyon quadrangle and from the Topanga formation in the vicinity of Cahuenga Pass is suitable and has been used in small quantities for the construction of dwellings and retaining walls. It is commonly of medium-coarse texture, hard, and gray to greenish gray and light brownish gray.

Large quantities of deeply weathered basalt suitable for road-surfacing material are easily accessible just west of Cahuenga Pass and in Topanga Canyon. A massive hard dark-gray intrusive rock, probably diorite, is associated with hard gray Chico limestone in Santa Ynez Canyon and is being quarried for minor construction purposes. 


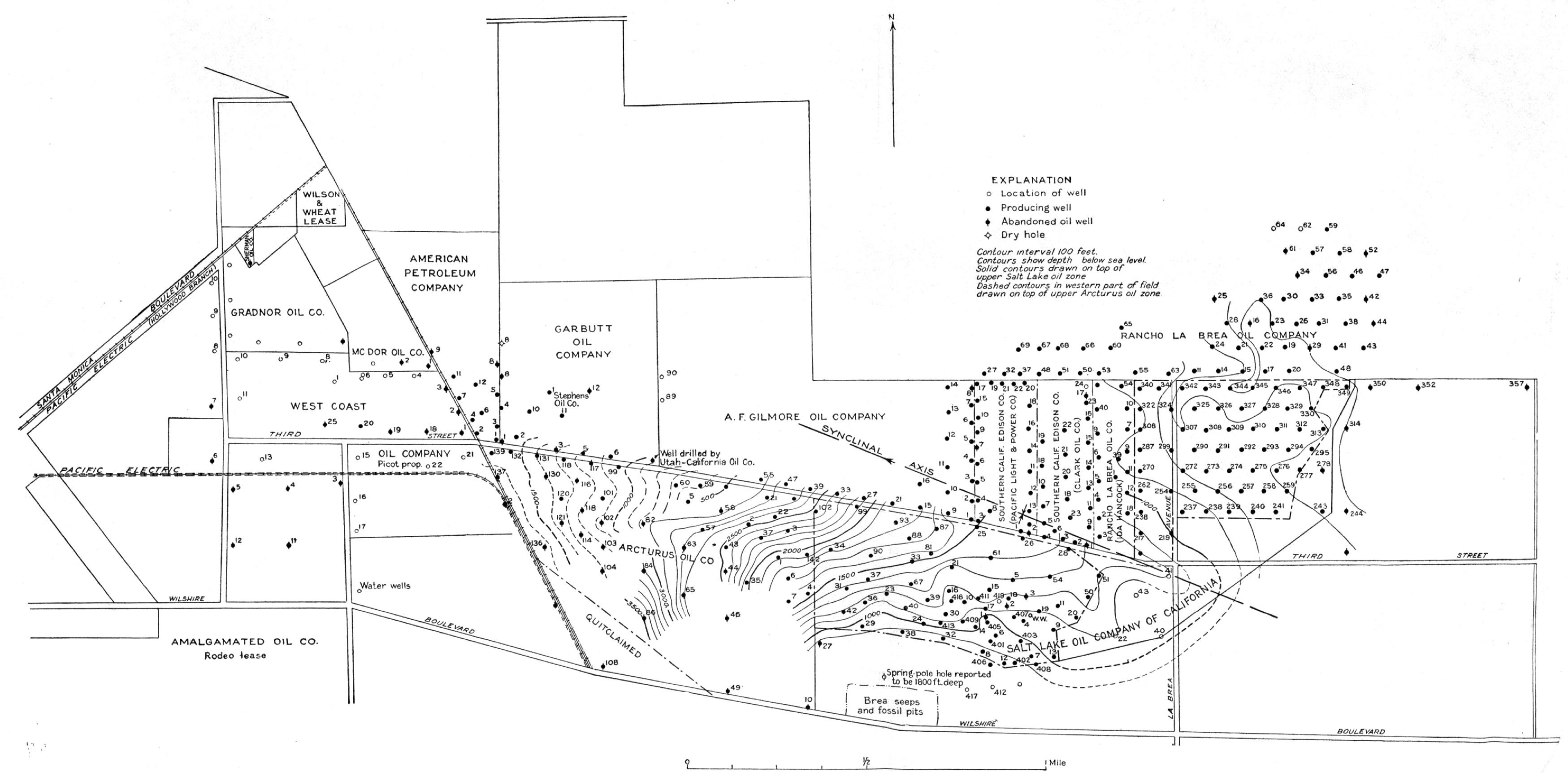

SUBSURFACE STRUCTURE CONTOUR MAP OF THE SALT LAKE OIL FIELD, CALIFORNIA Shows status of wells in 1917. After Joseph Jensen, Associated Oil Co. 


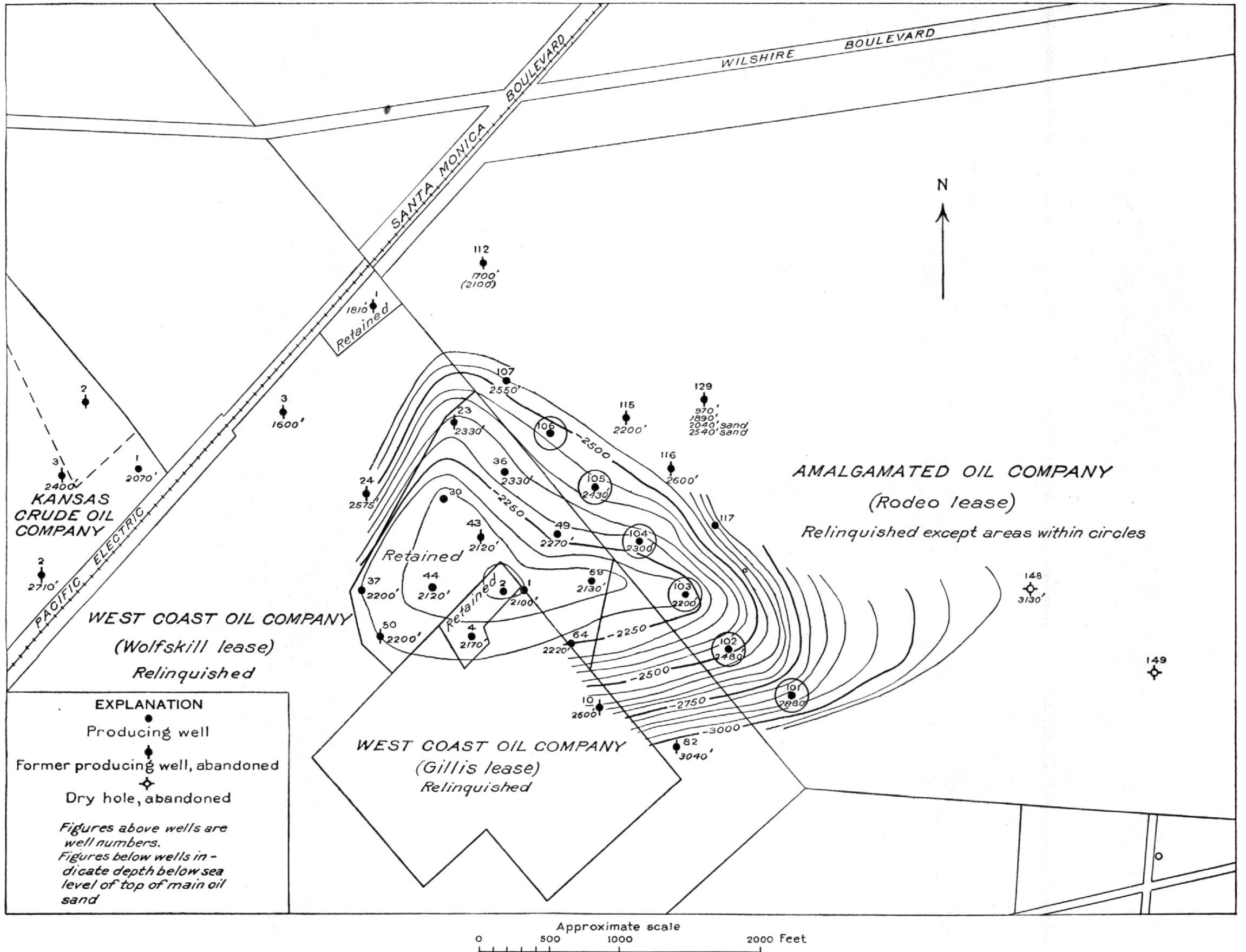

SUBSURFACE STRUCTURE CONTOUR MAP OF THE BEVERLY HILLS OIL FIELD, CALIFORNIA After Joseph Jensen, Associated Oil Co., 1928. 



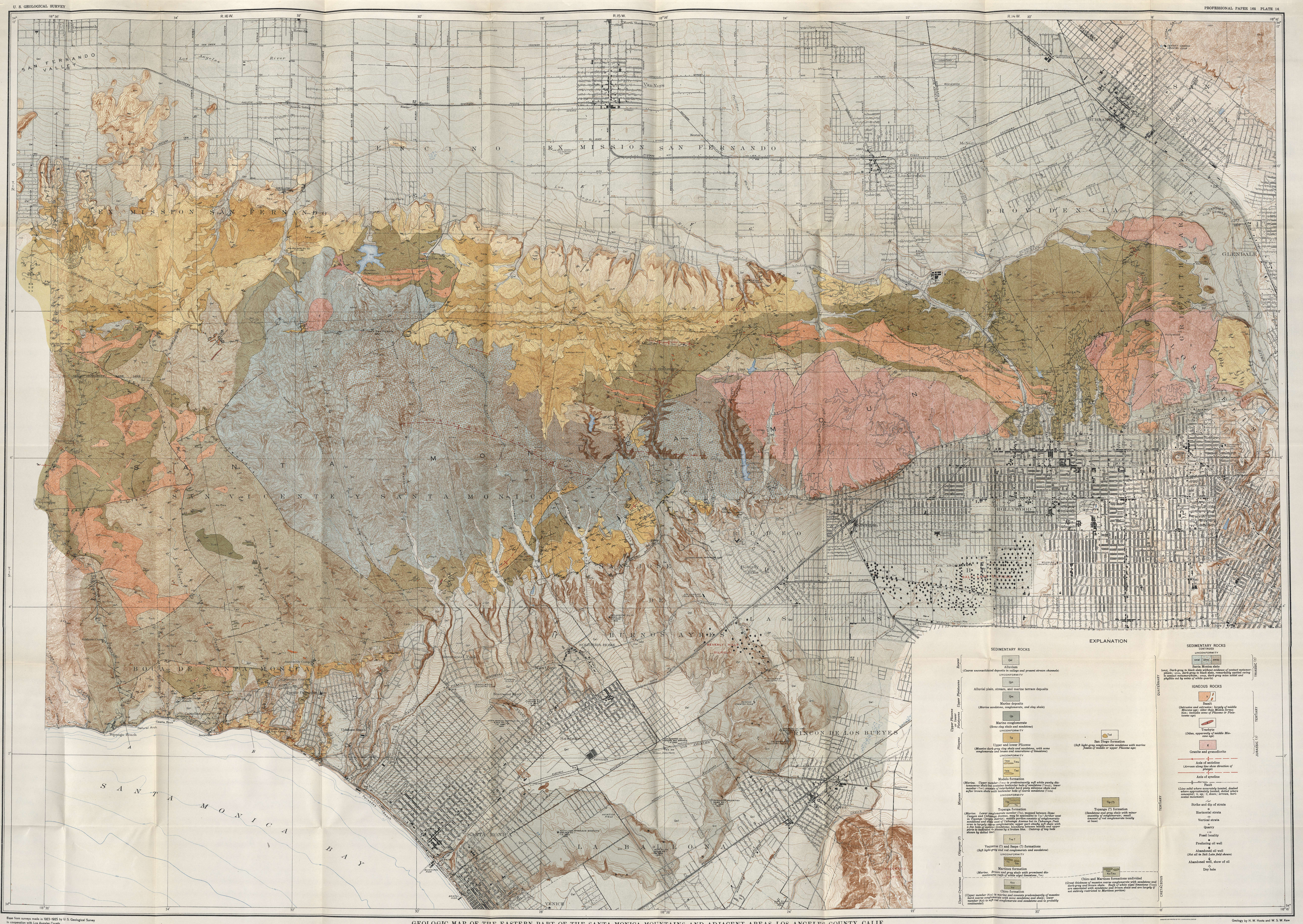

GEOLGGC MAP OF THE EASTRRN PART OF THE SANTA MONICA MOONTANSS AND AI 



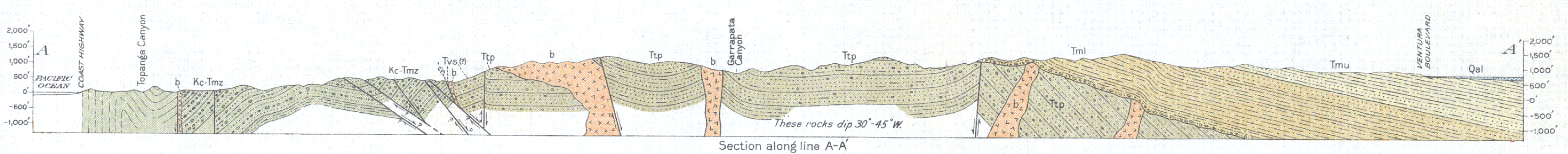

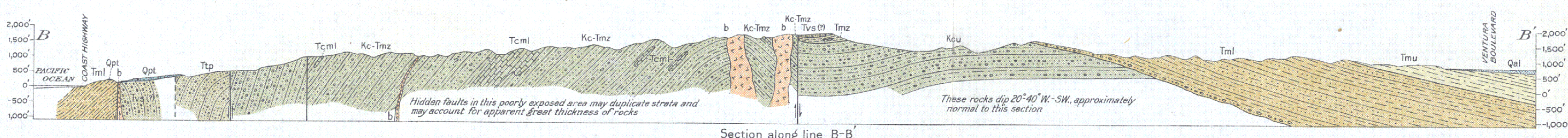
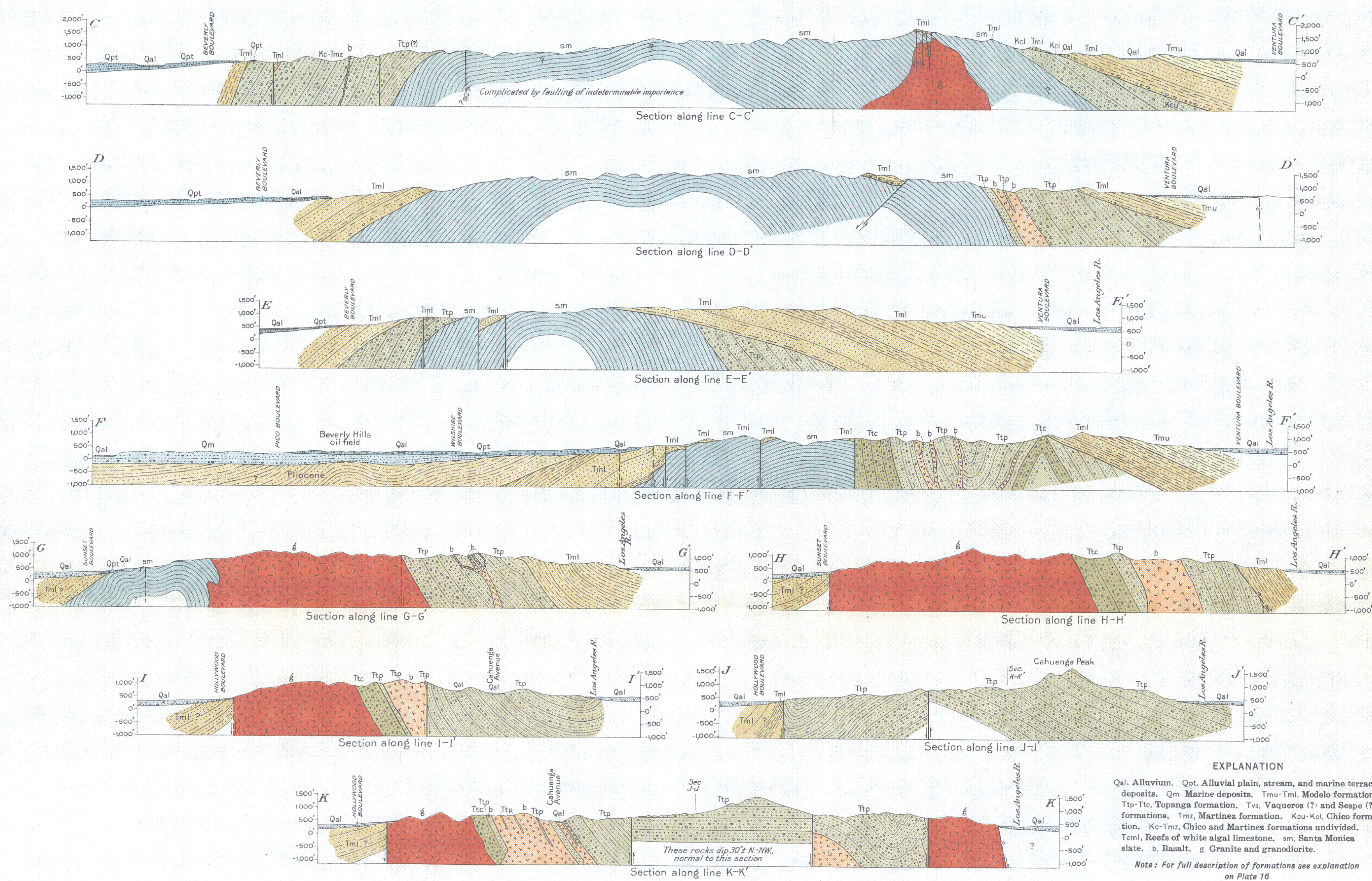

GEOLOGIC SECTIONS ACROSS THE EASTERN PART OF THE SANTA MONICA MOUNTAINS, CALIF.

$\left[\begin{array}{l}1931 \\ 2\end{array}\right.$ 



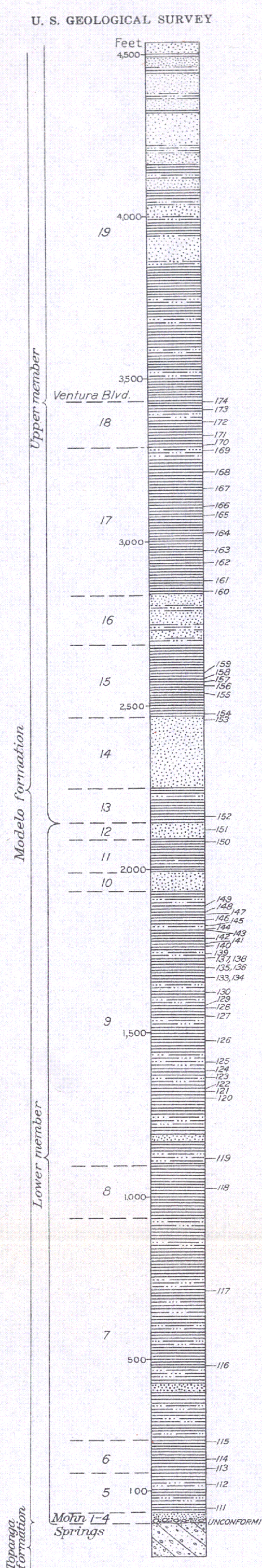

ECTION OF MODELO FORMATION NEAR GIRARD AND NORTHERN PAB
OF LINE A-A', PLATE 16 umbers $1-19$ at left indicate stratigraphic units
described in text; numbers at right indicate position of samples collected for Forams
nifera, etc., at localities shown on C

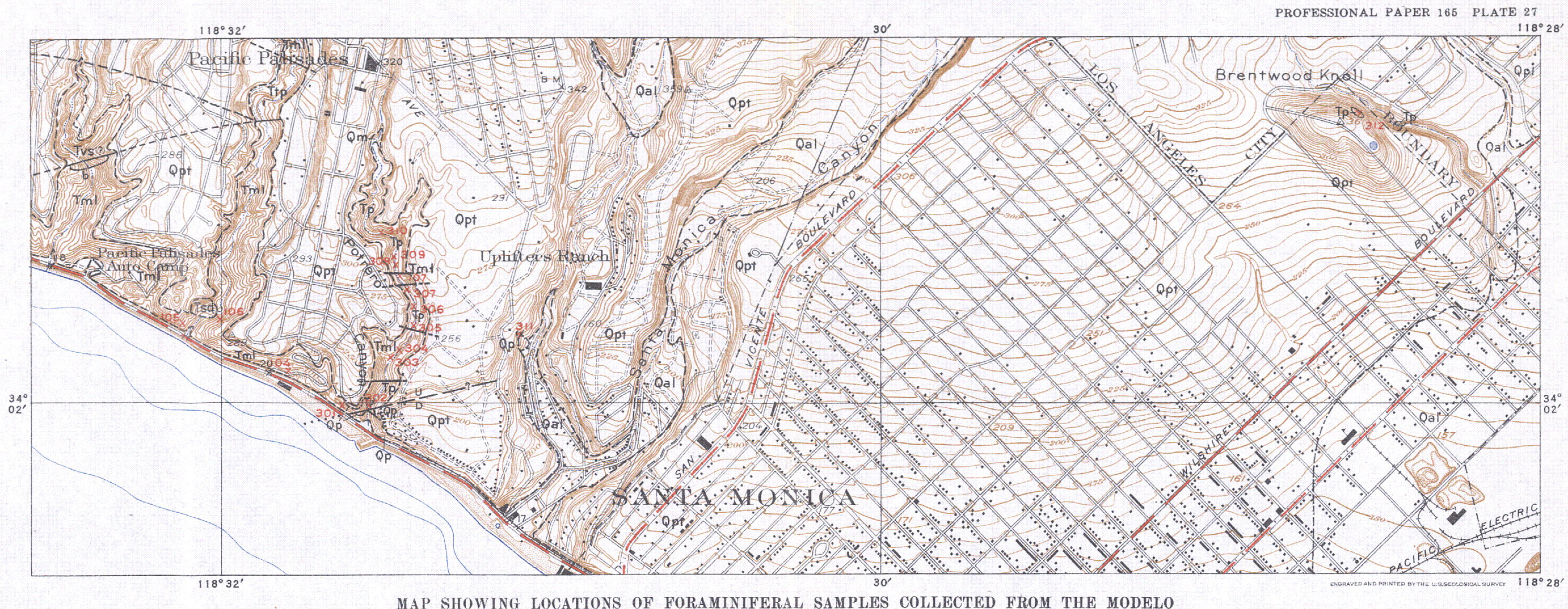

MAP SHOWING LOCATIONS OF FORAMINIFERAL SAMPLES COLLECTED FROM THE MODELO FORMATION AND UPPER AND LOWER PLIOCENE DEPOSITS NEAR SANTA MONICA Scale 24000

Contour interval on land 5 feet
Datumy is meean sea Zevel

EXPLANATION

Qal Alluvium
Qpt Upper Pleistocene alluvial plain, stream,

and marine terrace deposit

Marine upper Pleistocene

Marine upper Pliocene or lower Pleisto-

cene conglomerate

San Diego formation
Upper and lower Pli

Upuer member of Modelo formation

$\mathrm{Tml}$ Lower member of Modelo formation

Ttp Topanga formation

formations ?) Vaqueros (?) and

Tertiary basalt
Note: For full explanation of letter symbols

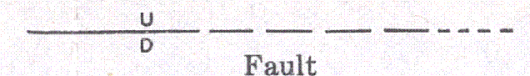

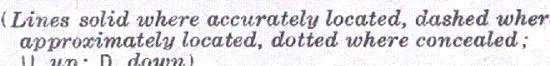

Locality where sample was
collected. (See text) ff shore at depths of 5,10 , and 25 feet.

B

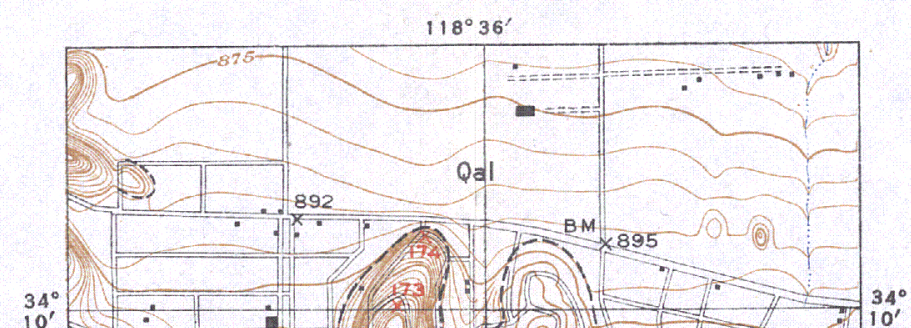

Mile

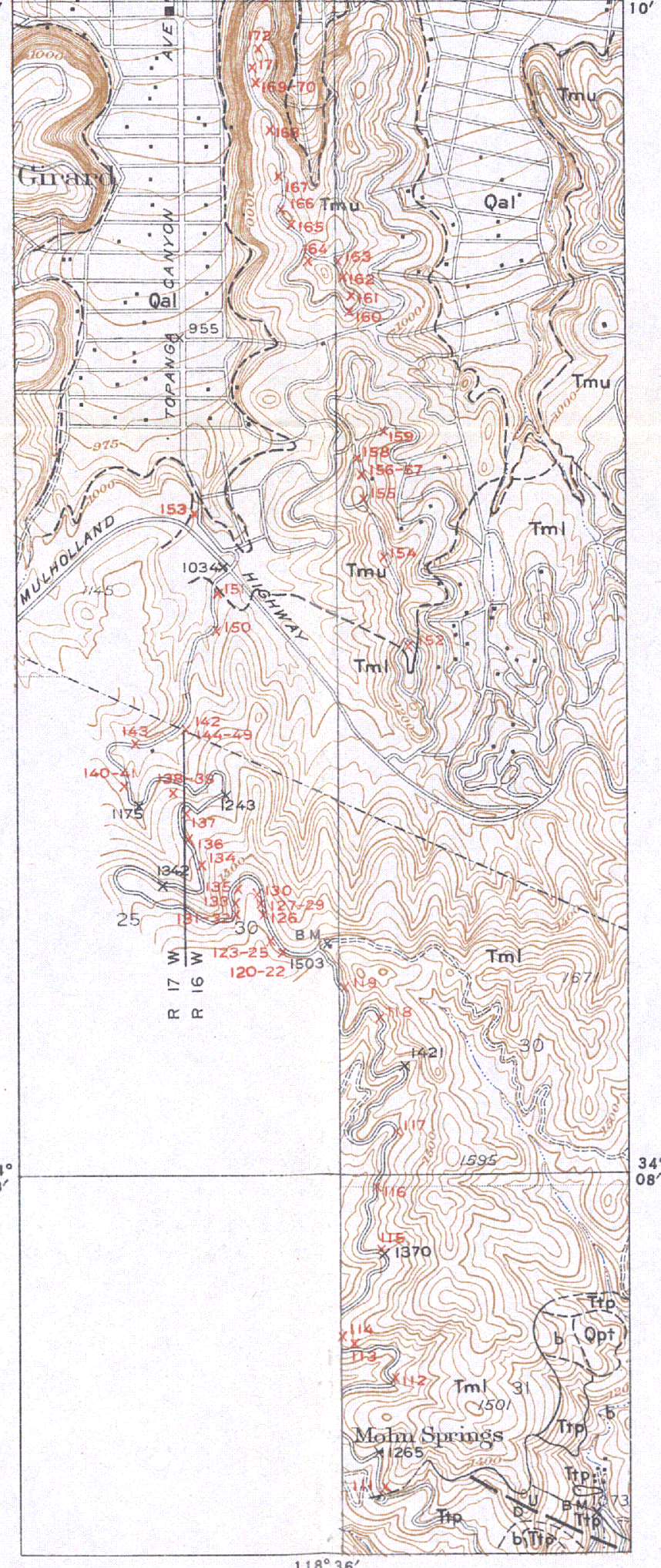

MAP SHOWIVG LOCATIOUS OF HOPAMINTFERAL SAMPLES COLLECTED FROM THE MODELO FORMATION NEAR GIRARD

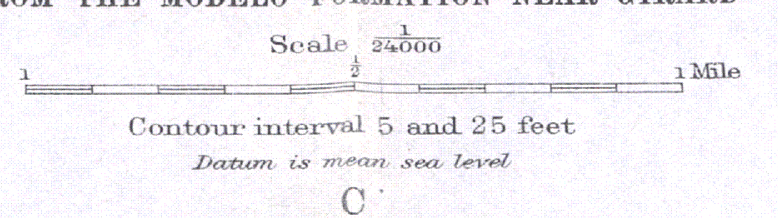


